In cooperation with the Mountains

Recreation and Conservation Authority

Geological, Hydrological, and Biological Issues Related to the Proposed Development of a Park at the Confluence of the Los Angeles River and the Arroyo Seco, Los Angeles County, California

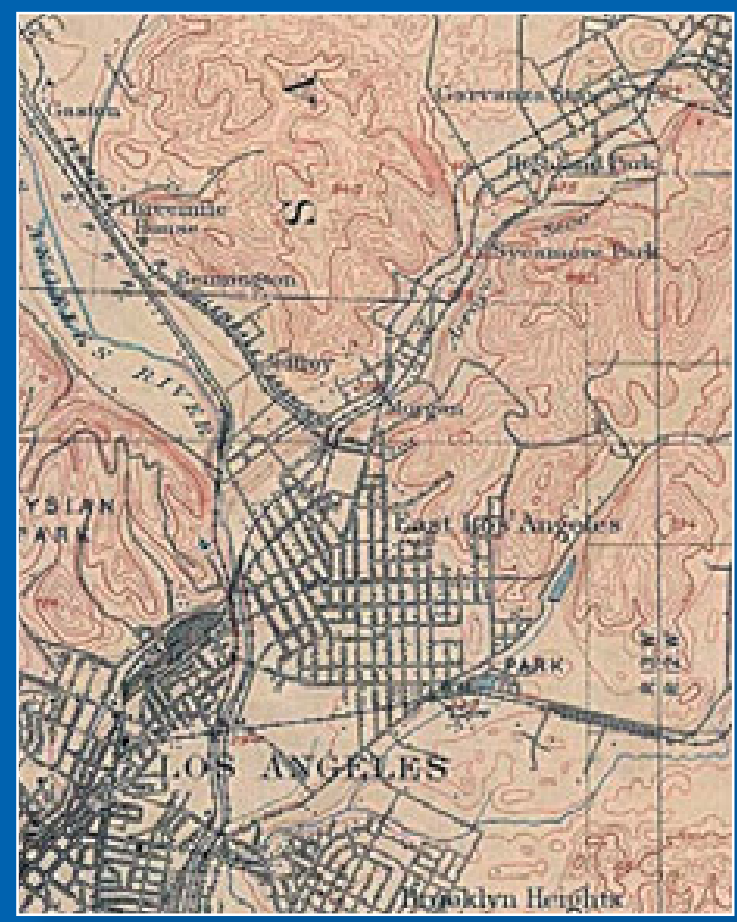

Scientific Investigations Report 2004-5296

U.S. Department of the Interior U.S. Geological Survey
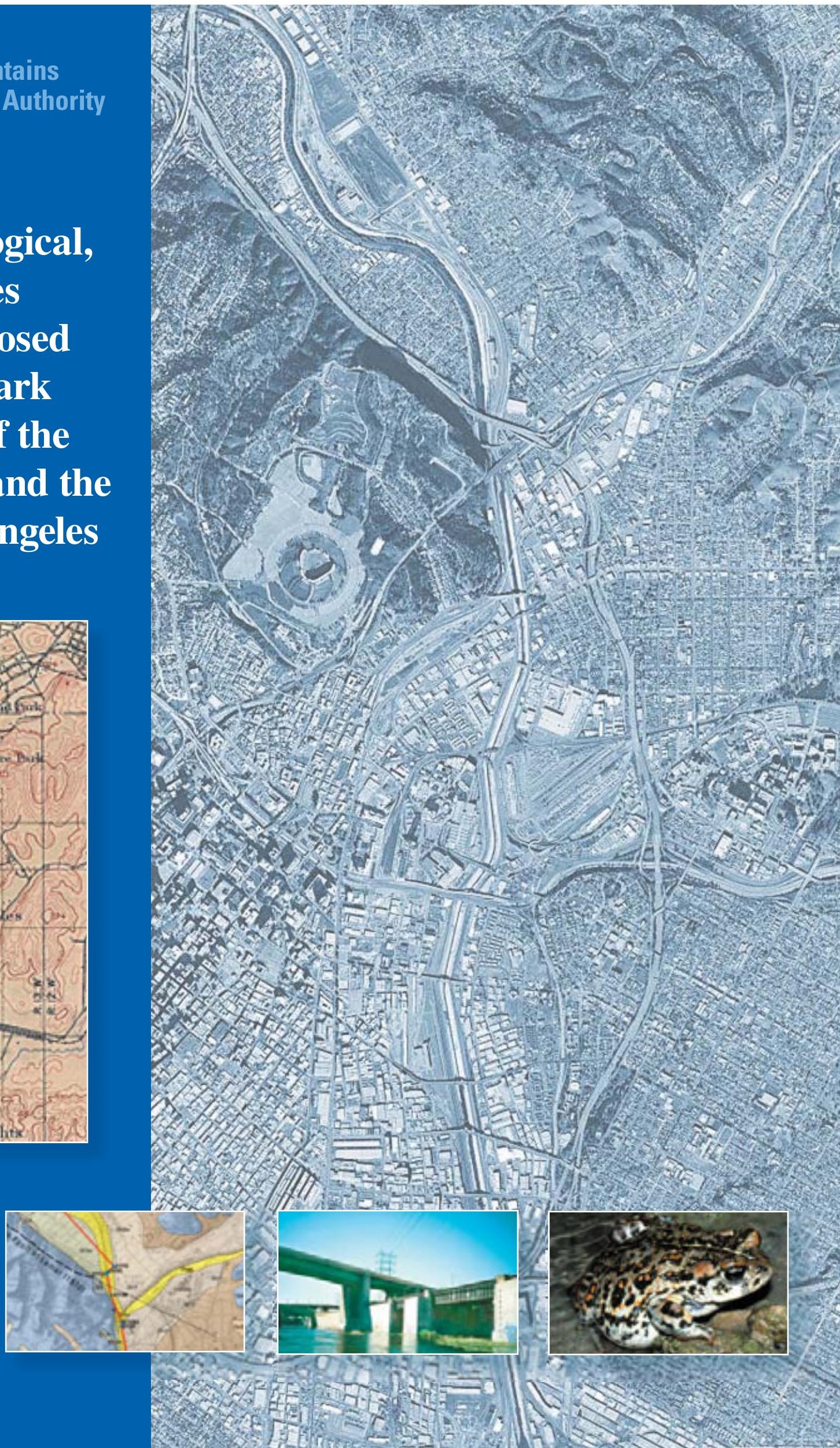


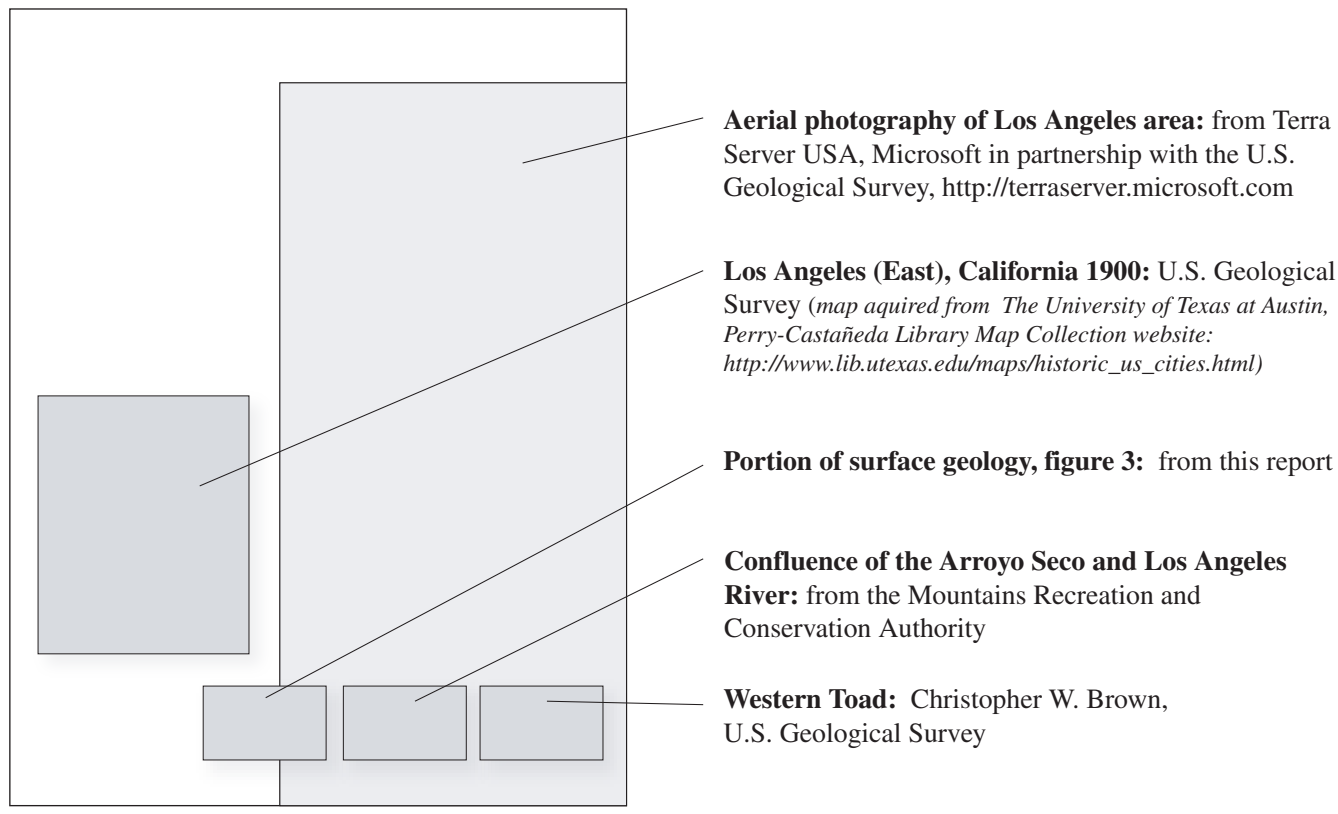




\section{Geological, Hydrological, and Biological Issues Related to the Proposed Development of a Park at the Confluence of the Los Angeles River and the Arroyo Seco, Los Angeles County, California}

By Michael Land, Peter C. Trenham, Daniel J. Ponti, Eric G. Reichard, John C.

Tinsley, Jonathan Warrick, and Robert W. Meyer

In cooperation with the Mountains Recreation and Conservation Authority

Scientific Investigations Report 2004-5296 


\section{U.S. Department of the Interior \\ Gale A. Norton, Secretary \\ U.S. Geological Survey \\ Charles G. Groat, Director}

U.S. Geological Survey, Reston, Virginia: 2005

For sale by U.S. Geological Survey, Information Services
Box 25286, Denver Federal Center
Denver, C0 80225
For more information about the USGS and its products:
Telephone: 1-888-ASK-USGS
World Wide Web: http://www.usgs.gov/

Any use of trade, product, or firm names in this publication is for descriptive purposes only and does not imply endorsement by the U.S. Government.

Although this report is in the public domain, permission must be secured from the individual copyright owners to reproduce any copyrighted materials contained within this report.

Suggested citation: Land, Michael, Trenham, P.C., Ponti, D.J., Reichard, E.G., Tinsely, J.C., Warrick, Jonathan, and Meyer, R.W., 2005, Geological, hydrological, and biological issues related to the proposed development of a park at the confluence of the Los Angeles River and the Arroyo Seco, Los Angeles County, California: U.S. Geological Survey Scientific Investigations Report 2004-5296, 49 p.

Michael Land, Peter C. Trenham, Daniel J. Ponti, Eric G. Reichard, John C. Tinsley, Jonathan Warrick, and Robert W. Meyer 


\section{Contents}

CONVERSION FACTORS, VERTICAL DATUM, ABBREVIATIONS, AND ACRONYMS $\quad . . \ldots \ldots \ldots$ vi

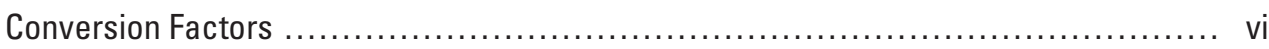

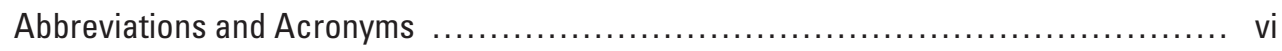

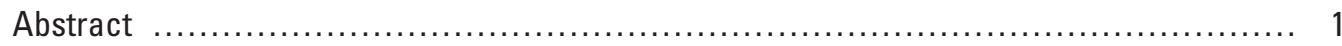

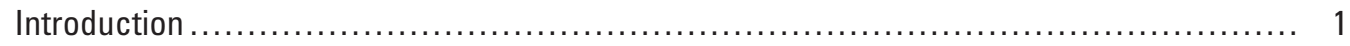

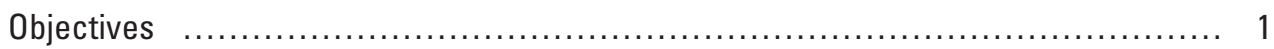

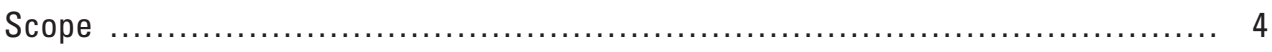

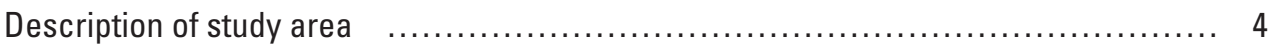

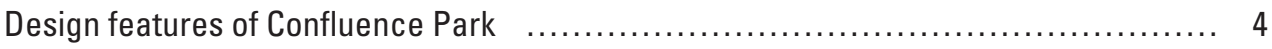

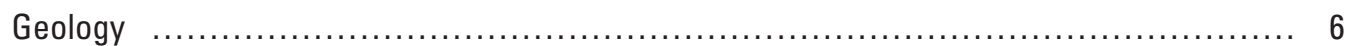

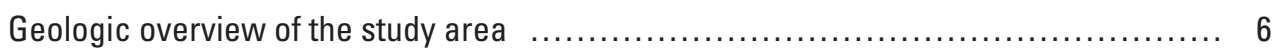

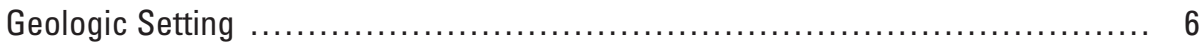

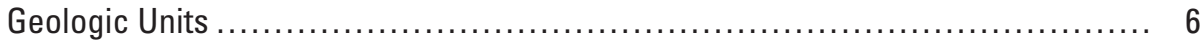

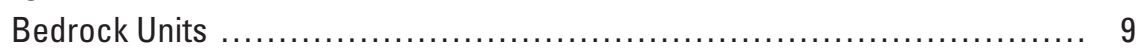

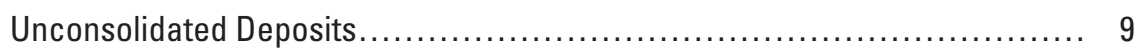

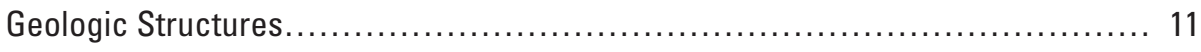

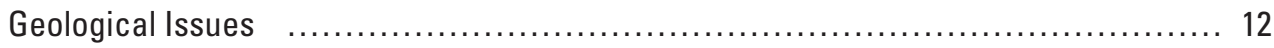

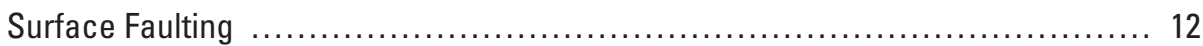

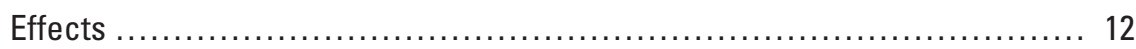

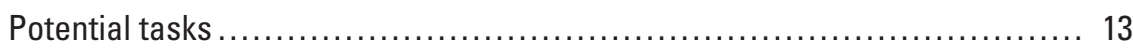

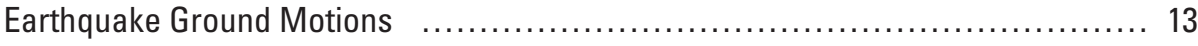

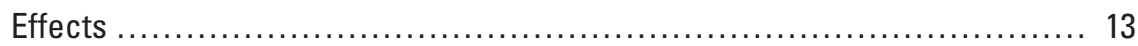

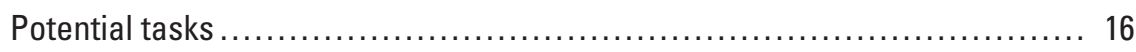

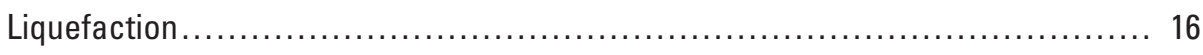

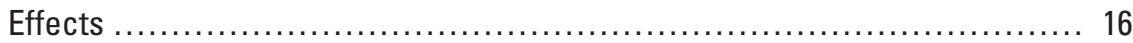

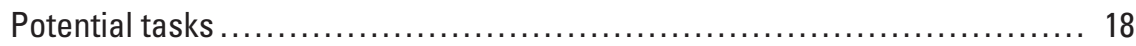

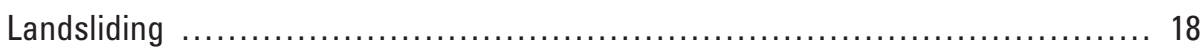

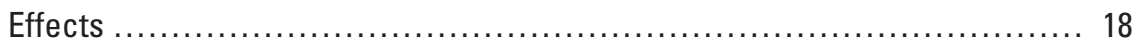

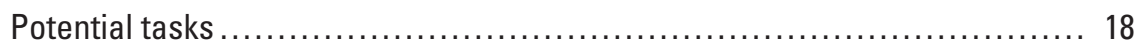

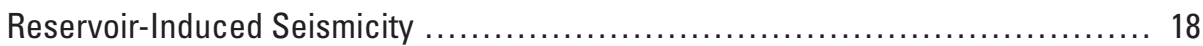

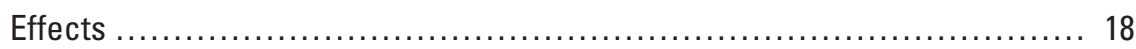

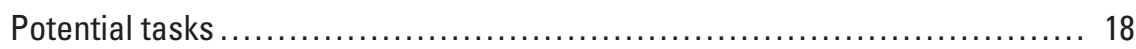

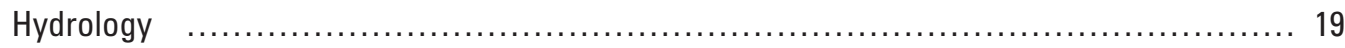

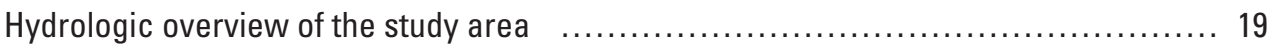

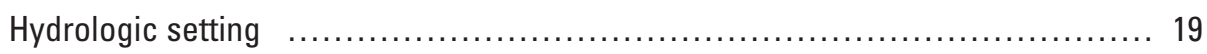

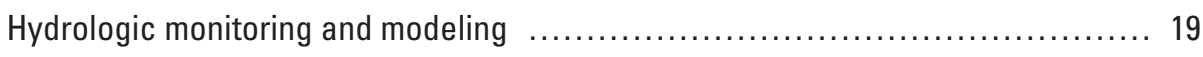

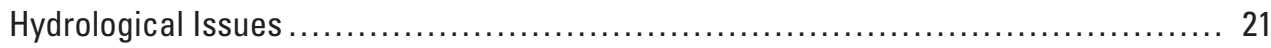

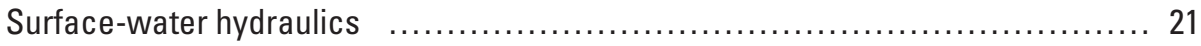

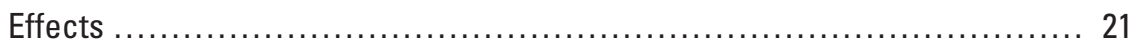

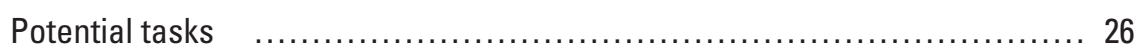

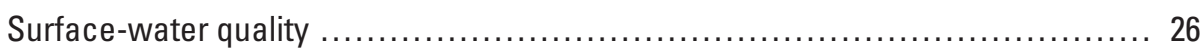

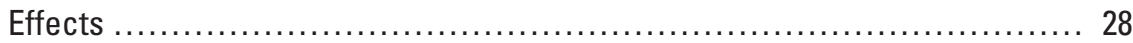




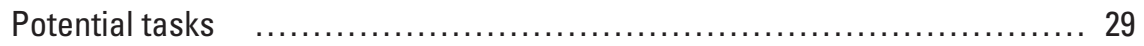

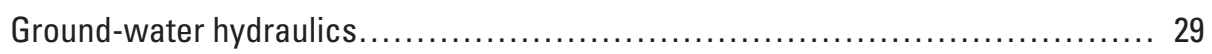

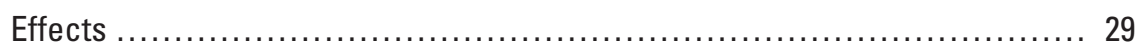

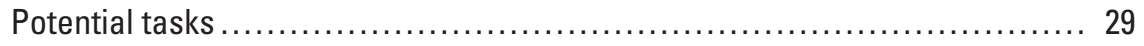

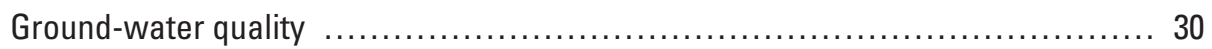

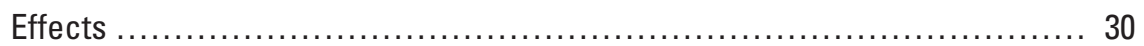

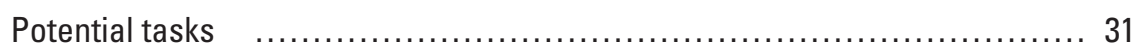

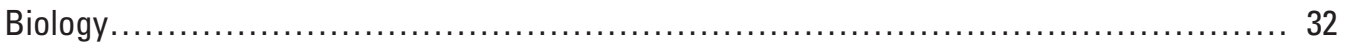

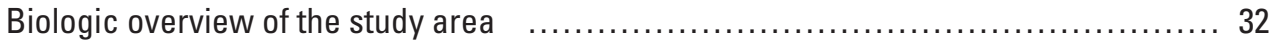

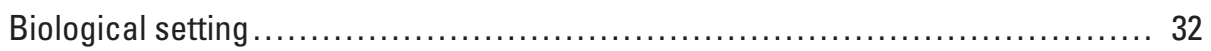

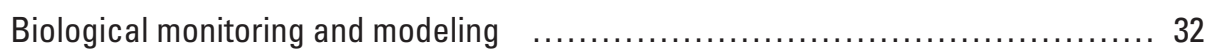

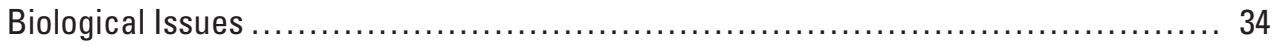

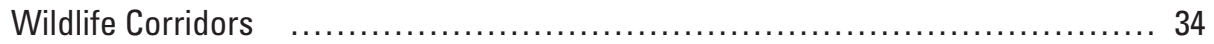

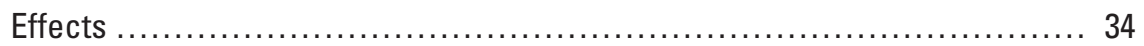

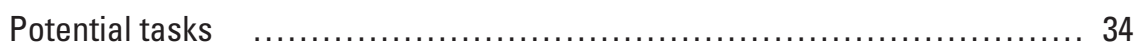

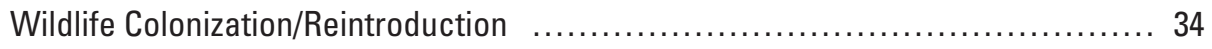

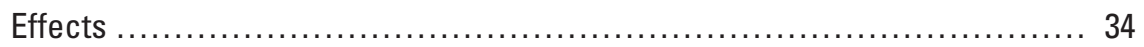

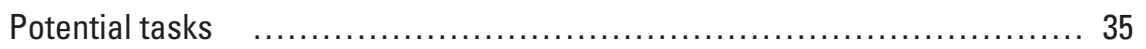

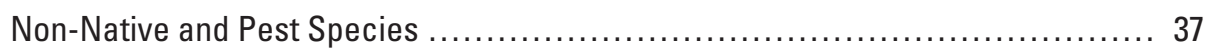

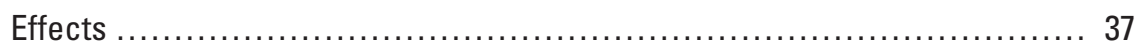

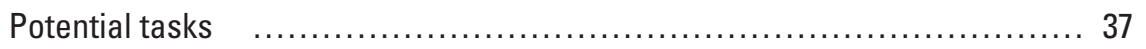

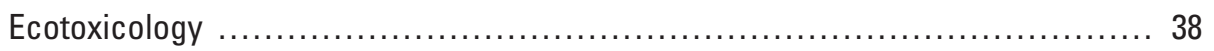

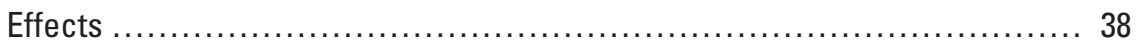

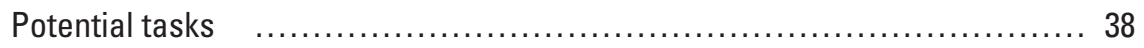

Options for Restoration of Local Habitat and Ecology ......................... 38

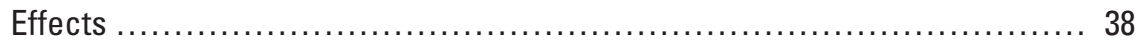

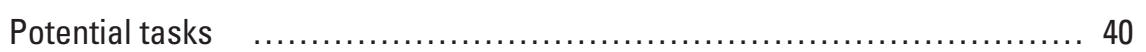

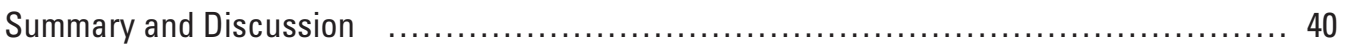

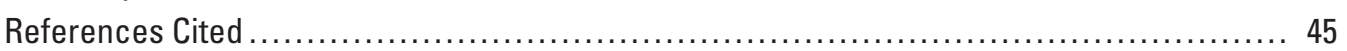

\section{Figures}

1. Map showing the Los Angeles coastal plain and vicinity, showing location of the confluence study area (yellow box-area of figure 2) and selected major faults ........... 2

2. Map showing the the Los Angeles River-Arroyo Seco confluence area and selected regional features of the study area................................................................. 3

3. Map showing the surface geology, geologic units and structures of the study area......... 7

4. Geological section A-A' near the Los Angeles River....................................................... 8

5. Predicted median peak ground acceleration in the confluence area from a scenario M7.1 earthquake on the Los Angeles segment of the Puente Hills Thrust

6. Map showing the predicted median peak ground acceleration in the confluence area from a scenario M6.4 earthquake on the Upper Elysian Park Thrust.................... 15

7. Map showing the liquefaction and landslide potential for the confluence area ............. 17

8. Map showing the location of precipitation stations, surface-water gaging stations, and ground-water wells in the study area and vicinity 
9. Graph showling the historical maximum daily discharge at the Los Angeles

River above Arroyo Seco (USGS 11097500, LACDPW F57C-R) for May through

September, 1932-2003

10. Graph showling the historical maximum daily discharge at Arroyo Seco near

Pasadena (USGS 11098000) for May through September, 1917-2003 23

11. Graph showling the number of days with flow exceeding 50 cubic feet per second at the Los Angeles River above Arroyo Seco (USGS 11097500, LACDPW F57C-R) for May through September 1932-2003

12. Graph showing the relation between river discharge and daily sediment load for the Los Angeles

River (USGS 1103000; see page 34) downstream from the study area

13. Boxplots showing the concentration of selected constituents in surface water from the Los Angeles River, 1966-1977(USGS stations 11097500 and 11097490)

14. Graphs showing the annual variation in temperature; relation between dissolved oxygen and temperature; and annual variation in specific conductance in water from the Los Angeles River, 1966-1977

15. Graph showing the water-level hydrograph for well 2781 (State of California well number 001S014WE003S) in the study area 30

16. Map showing the watershed boundaries, selected stream gages, and USGS biological research monitoring sites

\section{Tables}

1. Native vascular plants documented at sites along the Los Angeles River (Wallace, 1993).

2. Native species with potential to establish resident populations within the proposed Confluence Park

3. Summary of potential general tasks for urban-stream restoration projects and specific tasks for the proposed development of Confluence Park 


\section{CONVERSION FACTORS, VERTICAL DATUM, ABBREVIATIONS, AND ACRONYMS}

\section{Conversion Factors}

\begin{tabular}{rcl}
\hline Multiply & By & To obtain \\
\hline acre-foot per year (acre-ft/yr) & 1,233 & cubic meter per year \\
cubic foot per second (ft $3 / \mathrm{s})$ & 0.0283 & cubic meter per second \\
foot (ft) & 0.3048 & meter \\
foot per second (ft/s) & 0.3048 & meter per second \\
inch (in.) & 2.54 & centimeter \\
inch per year (in/yr) & 25.4 & millimeter per year \\
mile (mi) & 1.609 & kilometer \\
square miles & 2.590 & square kilometers \\
\hline
\end{tabular}

Temperature is given in degrees Celsius $\left({ }^{\circ} \mathrm{C}\right)$, which can be converted to degrees Fahrenheit $\left({ }^{\circ} \mathrm{F}\right)$ by the following equation:

$$
\left({ }^{\circ} \mathrm{F}\right)=9 / 5\left({ }^{\circ} \mathrm{C}\right)+32 .
$$

\section{Vertical Datum}

Sea level: In this report, "sea level" refers to the National Geodetic Vertical Datum of 1929 (NGVD of 1929) - a geodetic datum derived from a general adjustment of the first-order level nets of both the United States and Canada, formerly called Sea Level Datum of 1929.

Altitude: As used in this report, altitude refers to distance above or below sea level.

\section{Abbreviations and Acronyms}

$\begin{array}{ll}\text { CGS } & \text { California Geological Survey } \\ \text { g } & \text { acceleration of gravity } \\ \text { GIS } & \text { geographical information system } \\ \text { LACDPW } & \text { Los Angeles County Department of Public Works } \\ \text { LADWP } & \begin{array}{l}\text { Los Angeles Department of Water and Power } \\ \text { magnitude }\end{array} \\ \text { M } & \text { Mountains Recreation and Conservation Authority } \\ \text { MRCA } & \text { millions of years } \\ \text { Ma } & \text { standard penetrometer blow count } \\ \text { N } & \text { northeast } \\ \text { NE } & \text { National Pollutant Discharge Elimination System } \\ \text { NPDES } & \text { northwest } \\ \text { NW } & \text { Southern California Coastal Water Research Project } \\ \text { SCCWRP } & \text { southeast } \\ \text { SE } & \text { southwest } \\ \text { SW } & \text { Santa Monica Mountains Conservancy } \\ \text { SMMC } & \text { U.S. Environmental Protection Agency } \\ \text { USEPA } & \text { U.S. Geological Survey } \\ \text { USGS } & \text { volatile organic compounds } \\ \text { VOC } & \text { water reclamation plans } \\ \text { WRP } & \text { Water Replenishment District of Southern California } \\ \text { WRDSC } & \end{array}$




\title{
Geological, Hydrological, and Biological Issues Related to the Proposed Development of a Park at the Confluence of the Los Angeles River and the Arroyo Seco, Los Angeles County, California
}

\author{
By Michael Land, Peter C. Trenham, Daniel J. Ponti, Eric G. Reichard, John C. Tinsley, Jonathan Warrick, \\ and Robert W. Meyer
}

\section{Abstract}

A new park is being considered for the confluence of the Los Angeles River and the Arroyo Seco in Los Angeles County, California. Components of the park development may include creation of a temporary lake on the Los Angeles River, removal of channel lining along part of the Arroyo Seco, restoration of native plants, creation of walking paths, and building of facilities such as a boat ramp and a visitor center. This report, prepared in cooperation with the Mountains Recreation and Conservation Authority, delineates the geological, hydrological, and biological issues that may have an impact on the park development or result from development at the confluence, and identifies a set of tasks to help address these science issues.

Geologic issues of concern relate to surface faulting, earthquake ground motions, liquefaction, landsliding, and induced seismicity. Hydrologic issues of concern relate to the hydraulics and water quality of both surface water and ground water. Biological issues of concern include colonization-extinction dynamics, wildlife corridors, wildlife reintroduction, non-native species, ecotoxicology, and restoration of local habitat and ecology. Potential tasks include (1) basic data collection and follow-up monitoring, and (2) statistical and probabilistic analyses and simulation modeling of the seismic, hydraulic, and ecological processes that may have the greatest impact on the park. The science issues and associated tasks delineated for the proposed confluence park will also have transfer value for river restoration in other urban settings.

\section{Introduction}

The Mountains Recreation and Conservation Authority (MRCA) is considering plans for developing a new park at the confluence of the Los Angeles River and the Arroyo Seco in Los Angeles County, California (fig. 1, 2). This location is referred to as "the confluence" in the remainder of this report. The Arroyo Seco flows into the Los Angeles River at the southern end of the Glendale Narrows, just before the river enters the coastal plain. As in much of its 51-mi reach, the river here flows through a concrete-lined channel. Approximately 1,000 ft upstream from the confluence, the bottom of the Los Angeles River is unlined. The Arroyo Seco also is lined with concrete in this region.

The preliminary plans for the park include creation of a temporary lake (El Pueblo Lake) on the Los Angeles River using several inflatable rubber dams (City of Los Angeles, 2004). The lake, whose proposed location is shown in figure 2 , would extend from near the upstream end of the lined part of the Los Angeles River channel to about 1 mile downstream from the Arroyo Seco. The removal of some channel lining along the Arroyo Seco also is being considered. The implementation of a plan such as that being considered by the MRCA, will be affected by a wide array of scientific issues.

\section{Objectives}

The objectives of this study are to identify the most important geologic, hydrologic, and biologic issues related to the development of an urban park at the confluence of the Los Angeles River and Arroyo Seco, and to present a set of proposed work tasks to address these issues.

Although an initial concept for a park at the confluence has been developed (City of Los Angeles, 2004), the exact design has not yet been determined. Therefore, this study considers the range of potential hazards that could be encountered at the confluence, or impacts that could result from development at the confluence that may include impounding water with a temporary dam and possible removal of channel lining. Although the analyses are directed at a specific project proposed for a very small area, a goal of this report is to present a suite of science issues that has transfer value for river restoration in other urban settings. 


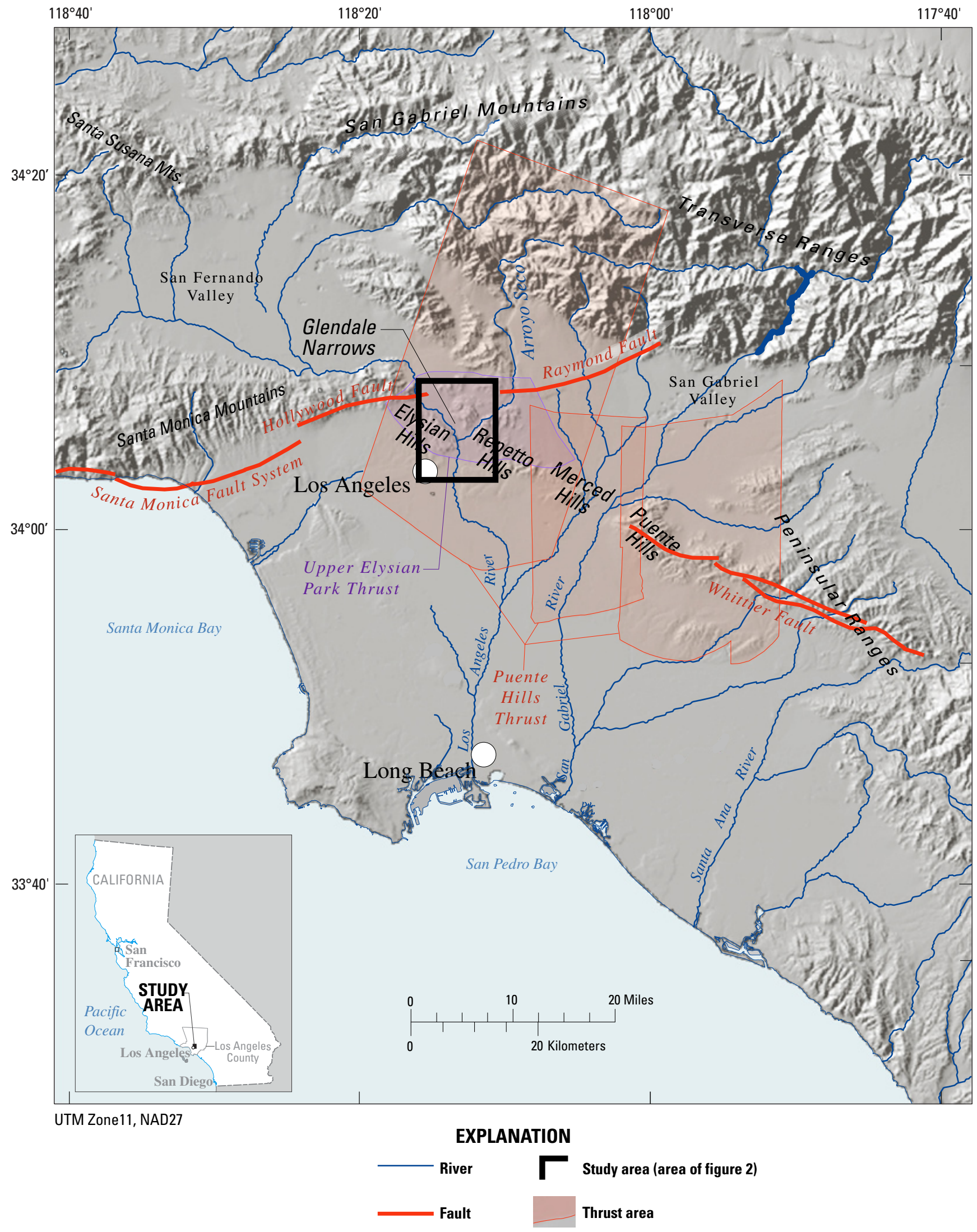

Figure 1. Los Angeles coastal plain and vicinity, showing location of the confluence study area and selected major faults. 


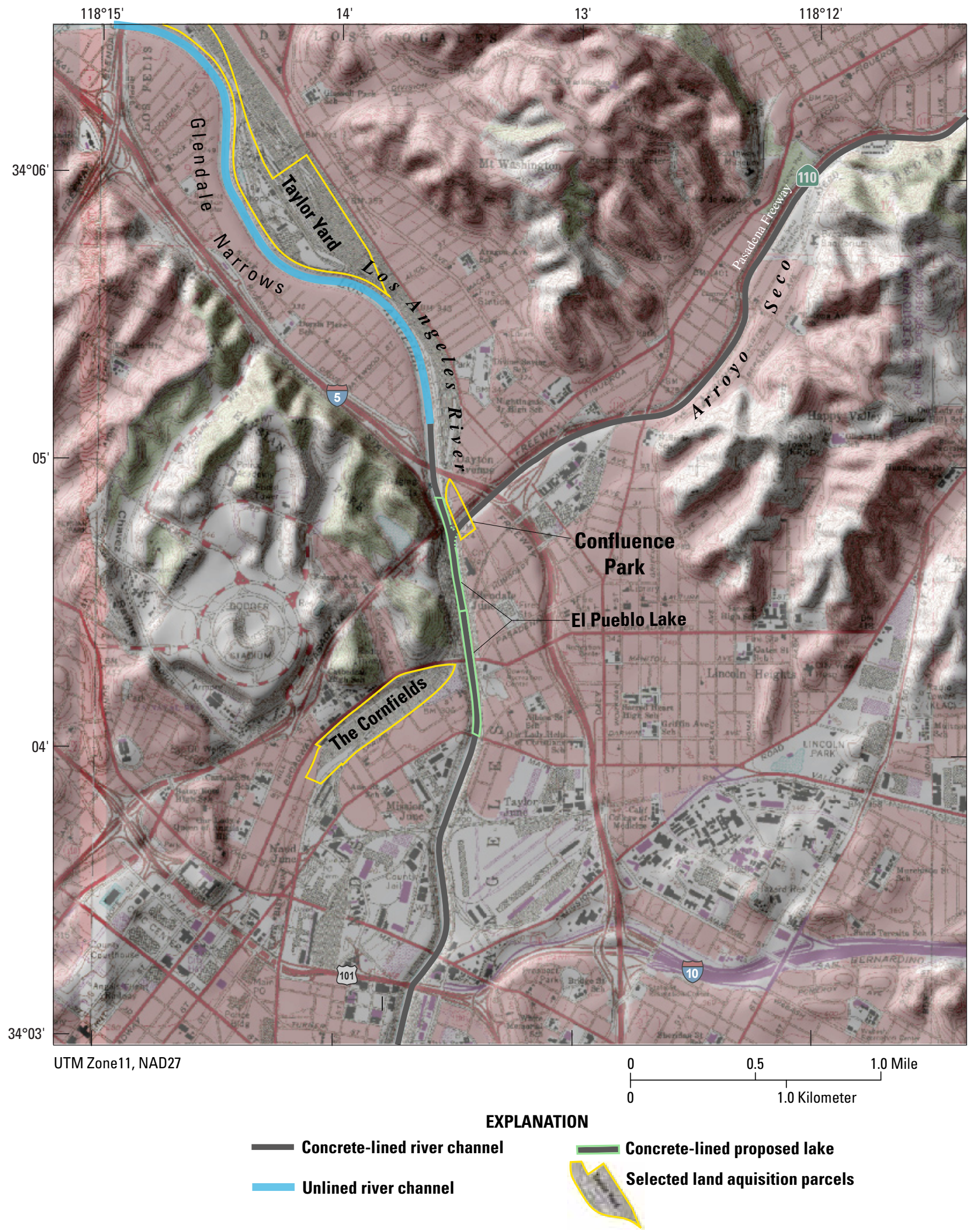

Figure 2. The Los Angeles River-Arroyo Seco confluence area and selected regional features of the study area. 


\section{Scope}

This report presents an assessment of the existing data and previous studies, delineates the geological, hydrological, and biological science issues of highest concern for the proposed park development, and identifies a suite of potential scientific studies and data-collection needs. The scope of work considers issues at the confluence, and, when necessary, includes some adjacent areas.

The report addresses geological, hydrological, and biological issues in separate sections. For each topical area, an overview of study area conditions is presented first. Next, specific issues that currently affect, or could potentially affect, the confluence area are discussed. A list of potential work tasks to help address these issues is then given.

\section{Description of study area}

The Los Angeles River and the Arroyo Seco are two of the principal rivers that drain the central Transverse Ranges and transport sediment across the coastal plain to the Pacific Ocean. The confluence of these two rivers occurs along the uplifted margin of the Los Angeles basin (fig. 1). This area, referred to in this report as the "Glendale Narrows", is a steep-sided valley, approximately $5 \mathrm{mi}$ in length, that separates the Elysian Hills and Santa Monica Mountains to the west from the Repetto Hills to the east. The Glendale Narrows was formed over the last 4 million years (approximately) by progressive erosion and downcutting of the Los Angeles River channel in response to broad-scale uplift and folding of the Santa Monica Mountains and the Elysian/Repetto foothills. Because erosion has been the dominant process in this area, the unconsolidated alluvial deposits in the Glendale Narrows are relatively thin and lie directly on top of a group of consolidated marine sandstone, siltstone, and shale.

The Los Angeles River drains 634 mi2 of the San Fernando Valley and coastal plain of Los Angeles. The Arroyo Seco has a drainage area of $46 \mathrm{mi} 2$ and originates in the San Gabriel Mountains. The pathway of the Los Angeles River across the coastal plain has shifted in historical times (California Department of Water Resources, 1961). Until the early 1800 s the river emptied into Santa Monica Bay (Gumprecht, 2001). The river currently drops about 3,000 vertical feet over a reach of approximately $51 \mathrm{mi}$.

The first settlements of what was to become the City of Los Angeles occurred in the vicinity of the confluence. The Los Angeles River was the source of water supply through both direct diversions and indirect extraction through the use of infiltration galleries (Gumprecht, 2001). The river also was the center of a rich ecosystem. The Natural History Museum of Los Angeles compiled a review of the historical and current biological resources of the Los Angeles River (Garrett, 1993). A variety of native species now listed as threatened and endangered were formerly present, including grizzly bear, California condor, southwestern willow flycatcher, southern steelhead, unarmored threespine stickleback, and red-legged frog. However, with the channelization of the Los Angeles River and urbanization of the surrounding lands, these and other species have declined or disappeared.

As Los Angeles grew through the late 1800s and into the early 20th century, the Los Angeles River continued to be at the centroid of urbanization. The river systems and the growing city strongly affected one another. In addition to being a source of water supply, the river channel also became a site for disposal of waste (Gumprecht, 2001). Flooding along the river, especially during 1914, 1934, and 1938, resulted in extensive loss of life and property. In response to these large storm events, numerous flood control projects were implemented along the Los Angeles River and its tributaries. These projects included reservoir construction, installation of catchment basins, and channelization of the river. Intensive channelization began in 1938.

Today, about 48 of the Los Angeles River's 51 mi are lined with concrete (Los Angeles County Department of Public Works, 2004, http://la/dpw.org/wmd/watershed/la (10/14/2004). In addition to their flood control benefits, these projects have had impacts on the overall hydrologic regimeincluding surface-water/ground-water interaction-and on the ecosystem. The upper part of the Glendale Narrows is one of the few portions of the Los Angeles River that is not lined on the bottom. Lining was not installed here because of rising ground water. The Arroyo Seco also is mostly lined from its confluence with the Los Angeles River upstream to Pasadena. In addition to the direct effects of the river control projects, the river system has been affected by other aspects of urbanization. The flow regime increasingly has been dominated by discharge from water-reclamation facilities and from urban discharge. In addition, the water quality of the river has been affected by these new sources. The confluence area has a long history of industrial activities (for example, Taylor Yard and The Cornfields, shown in fig. 2), which have been sources of environmental contamination.

At the beginning of the 21 st century, numerous plans are being considered for restoring components of the Los Angeles River to more "natural" conditions. One plan under consideration by the MRCA is the development of a park at the confluence.

\section{Design features of Confluence Park}

The initial concept for a park at the confluence (referred to as "Confluence Park") is to construct a temporary recreational lake on the Los Angeles River. A tentative plan delineated by the City of Los Angeles (2004) would include one 6-ft- and two 16-ft-high inflatable dams inundating a section of the Los Angeles River channel about $200 \mathrm{ft}$ wide and about 4,500 ft long. The river in this area has a slope of approximately 0.0044 . The average depth of the lake would be about $11 \mathrm{ft}$, ranging from about $6 \mathrm{ft}$ at the upstream end to $16 \mathrm{ft}$ at the downstream end. The total volume in the lake 


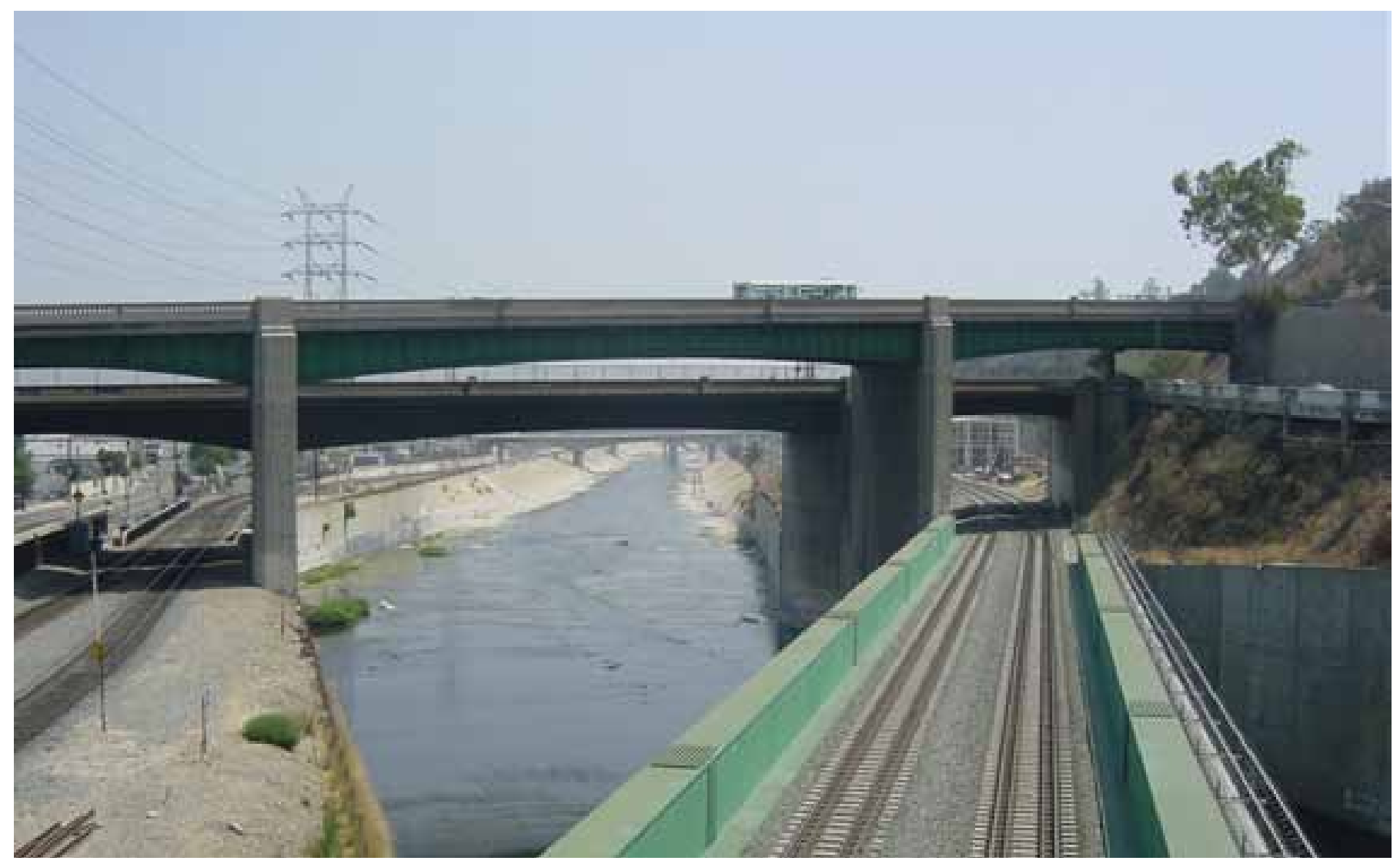

South facing view of the urbanized Los Angeles River and Arroyo Seco confluence (photograph by Dale Cox, U.S. Geological Survey)

would be approximately 220 acre-ft. The approximate location of the proposed lake (referred to as "El Pueblo Lake") is shown in figure 2. The upper boundary of the lake would be just downstream of the beginning of the lined part of the Los Angeles River channel. The lake would also extend several hundred feet upstream into the Arroyo Seco. The dam structures would be inflated during late spring through late summer months.

The proposed lake would be used for boating. According to the initial concept, features adjacent to the temporary lake could include docks, boat ramps, cafes, and restrooms. In addition to creation of the temporary lake, the MRCA also is considering removal of some of the channel lining in the Arroyo Seco as part of the project. Confluence Park, as expressed by the MRCA, "is envisioned as a series of urban spaces that combine public open space, an outdoor classroom, safe, attractive pedestrian and bike paths, public art, and the vision of a restored riparian ecosystem....Development of Confluence Park will include site cleanup, native plant restoration, landscaping, and creation of walking paths, community access, restrooms, a visitor center, a bicycle station, benches, educational displays and interpretive exhibits that tell the story of the expansion of Los Angeles into its original suburbs and [its] relationship to transportation, nature and culture" (Santa Monica Mountains Conservancy, 2003). The planned Confluence Park and El Pueblo Lake would be a part of a larger set of restoration projects to improve recreational opportunities, enhance ecological communities, and foster economic development along the river from the headwaters to the bay (Price, 2003; California Resources Agency, 2001; Los Angeles County Department of Public Works, 2003). 


\section{Geology}

\section{Geologic overview of the study area}

\section{Geologic Setting}

The Los Angeles River-Arroyo Seco confluence area lies at the northern margin of the Los Angeles coastal plain, a deep, sediment-filled basin between the Transverse and Peninsular Ranges in coastal southern California (fig. 1). Bounded beneath Mesozoic granitic rocks and the Catalina Schist, the basin contains strata as much as 6 mi thick that range in age from Late Cretaceous (65 to 99 million years ago [Ma]) to the present (Yerkes and others, 1965). Basin inception began in the Early to Middle Miocene (less than $24 \mathrm{Ma}$ ), as a result of regional crustal extension related to the creation of the San Andreas Fault system (Atwater, 1970). As much as 10,000 feet of marine sediment, with interbedded volcanic rocks, was deposited in the basin during the Miocene. This depositional regime continued until about $4 \mathrm{Ma}$ when a transition to the present-day tectonic regime, dominated by strike-slip and reverse faults, began to form the current NW-SE trending basin geometry (Yerkes and others, 1965). Initiation of compressional tectonics in the region significantly deepened the basin and uplifted its margins, and caused great thicknesses of marine sediment to be deposited in the basin during the Pliocene and Early to Middle Pleistocene epochs. Rapid growth of the basin-bounding mountain ranges also began during the Pliocene. Over the past approximately $3 \mathrm{Ma}$, uplift and erosion of the surrounding mountains eventually overtook basin subsidence, and the combination of tectonic deformation and basin-filling gradually produced the configuration of the present coastline. Sediment deposited in the basin over the past several hundred thousand years, particularly near the inner margins of the basin, is primarily of fluvial origin. These river-laid deposits are generally quite thin, as most sediment now being eroded from the Transverse and Peninsular Ranges is transported across the coastal plain and deposited offshore (California Department of Water Resources, Southern District, 1961).

The alluvial sediment deposited by the Los Angeles River and the Arroyo Seco in the confluence area is of Quaternary age and reflects several cycles of river aggradation and erosion. The Quaternary Period, composed of the Pleistocene (1.8 to $0.01 \mathrm{Ma}$ ) and Holocene (0.01 Ma to present) epochs, is notable for extreme changes in global climate that resulted in numerous glacial and interglacial episodes. Although the Los Angeles region did not experience glaciation directly during the Pleistocene, the glacial periods had weather patterns that produced cooler and wetter climates in southern California. Consequently the upland regions were more densely vegetated with deep-rooted coniferous and oak forests during glacial episodes than they were during interglacial episodes characterized by a drier climate and chaparral-dominated vegetation conditions similar to those of today (McFadden, 1982). The more dense and deeply rooted vegetation and the cooler, wetter climates promoted rock and soil weathering and resulted in thicker soil mantles in the upland areas. The denser vegetation stabilized slopes and thus reduced the influx of sediment to the region's rivers. Elsewhere in North America and Eurasia, the growth of continental and mountain glaciers caused worldwide sea level to decrease by approximately 300 feet, causing coastal rivers, such as the Los Angeles River and the Arroyo Seco, to grade to a lower base level. The reduced sediment supply and lowered base levels during glacial periods caused rivers to downcut and erode their banks. As the climate warmed up during the transition to an interglacial period, the vegetation thinned and sea level rose. Both of these conditions led to stream aggradation as weathered hillslope material produced during the glacial period was released into the streams and as the overloaded rivers deposited sediment from a new, steeper gradient. Eventually, as both sediment influx and streamflows decreased during the full interglacial, aggradation slowed or ceased and the rivers incised and reworked deposits as channels migrated across flood plains. These repeated cycles of erosion, stream aggradation, and sediment reworking in the confluence area have left laterally and vertically complex river terrace and flood-plain deposits composed of gravelly to silty sediment. The lithologic variability of these deposits affects their geotechnical character (for example, density, permeability, shear-wave velocity), which has implications for engineering activities associated with the confluence restoration project.

\section{Geologic Units}

A geologic map (fig. 3) and an interpretive geologic cross-section along the alignment of the Los Angeles River from Fletcher Drive on the north to Cesar Chavez Avenue on the south (fig. 4) shows the general distribution and character of exposed and near-surface rocks in the confluence area. Although additional rock units are shown, the map and geologic section were constructed from available sources to specifically highlight (1) sequences of Holocene and Pleistocene alluvial units that were produced presumably by major climatic fluctuations, and (2) the lithologic character within each sequence. Sources used for this compilation included geologic maps (Lamar, 1970; Yerkes and others, 1977), soils maps (Nelson and others, 1919), and water well and geotechnical borehole logs from U.S. Geological Survey (USGS) files. 


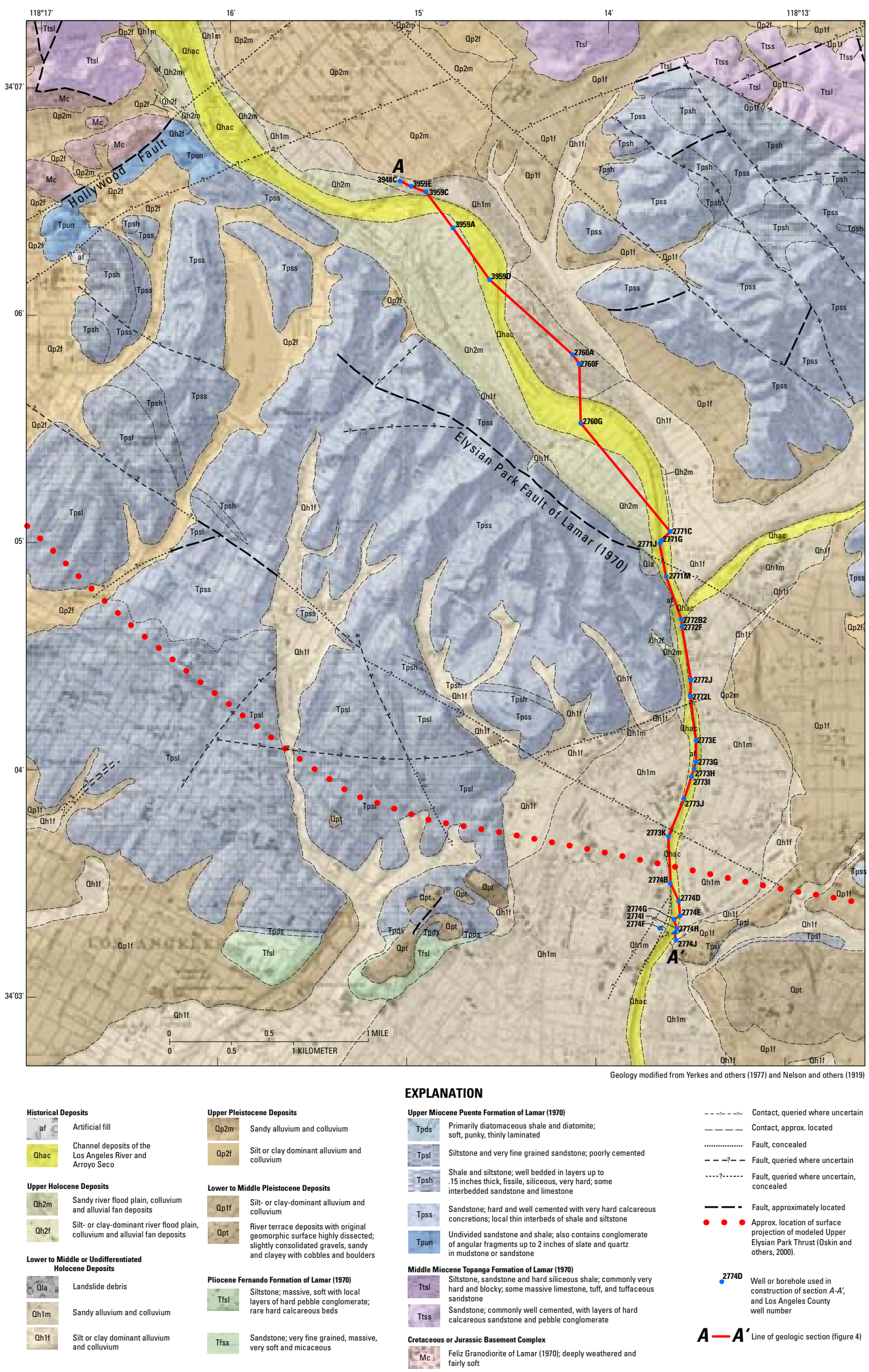

Figure 3. Surface geology, geologic units, and structures of the study area. 

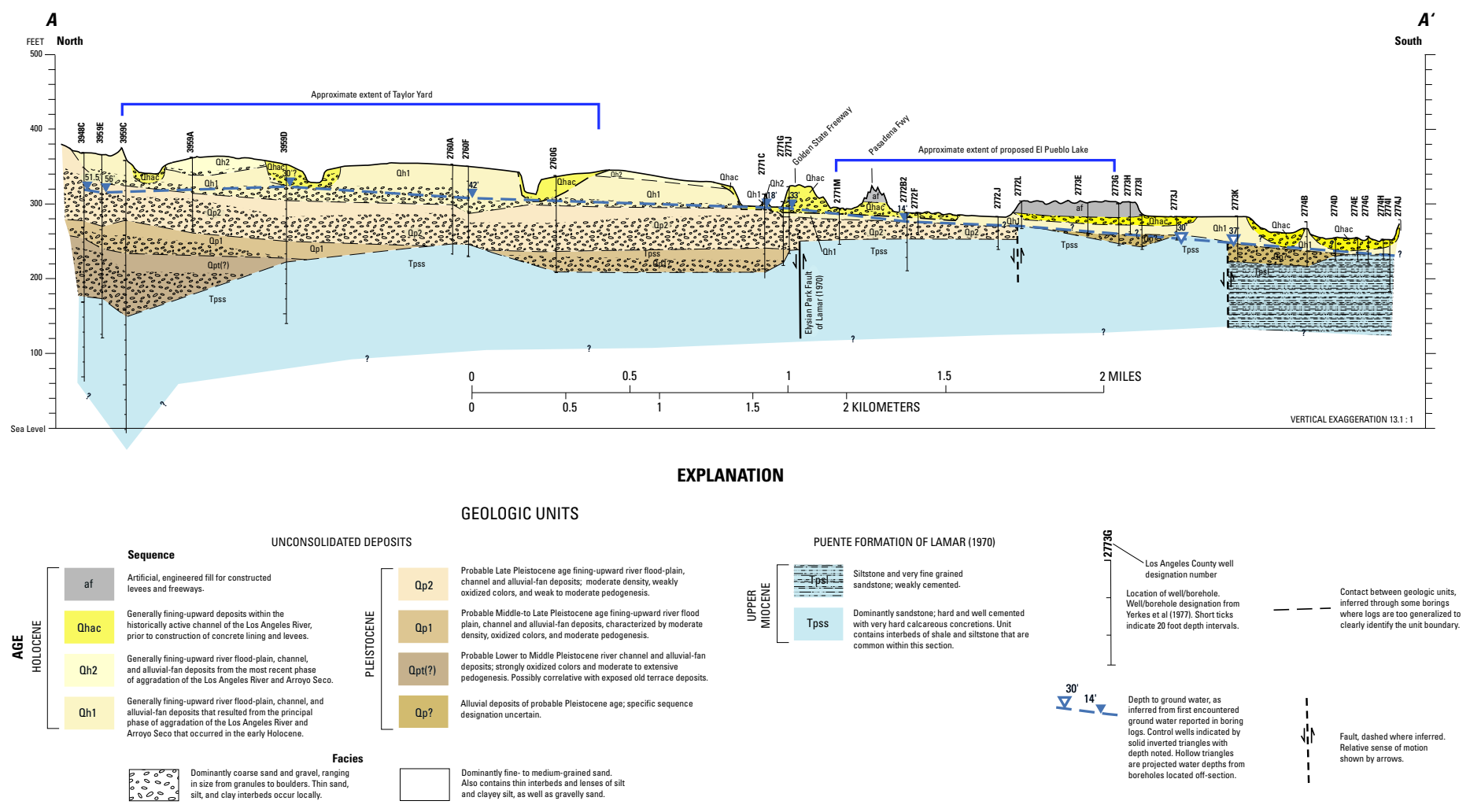

Figure 4. Geological section $A-A^{\prime}$ near the Los Angeles River.

Please click on the figure to open an 11" $\times 17$ " printable version or go to: http://water.usgs.gov/pubs/sir/2004/5296/04-5296_confluence_park/Fig4-Confluence\%20Section.pdf 


\section{Bedrock Units}

The distribution of Mesozoic and Tertiary-age rocks of the confluence area as mapped by Lamar (1970) are shown in figure 3. These rocks crop out in the Elysian and Repetto Hills and are encountered at depths of less than 200 feet beneath the Quaternary alluvial sediment in the Glendale Narrows and at depths generally less than 50 feet directly beneath the proposed location of El Pueblo Lake. These rocks are typically consolidated, either weakly or strongly cemented and, as such, provide a nearly impermeable "floor" to the unconsolidated alluvial deposits that directly underlie the confluence area.

Feliz Granodiorite (pre-Upper Cretaceous, Mc) - This plutonic igneous rock is exposed at the southeastern end of the Santa Monica Mountains, north of the Hollywood Fault. The rock is part of the Peninsular Ranges basement complex. Where exposed, this rock is deeply weathered, fairly soft, and dull gray to light brown in color (Lamar, 1970).

Topanga Formation (Middle Miocene, Tt) - This unit crops out in the extreme northwest and northeast parts of the study area (fig. 3) and consists of siltstone, sandstone, and siliceous shale (Ttsl), and well-cemented sandstone, calcareous sandstone, and pebble conglomerate (Ttss). Sedimentary features indicate that the unit was deposited in an open marine environment, most likely by turbidity currents. The formation is structurally complex: bedding is tightly folded and cut by faults. These rocks are distinguished from the overlying Puente Formation on the basis of their characteristic blocky weathering, brown color, and dark brown coatings on weathered surfaces (Lamar, 1970).

Puente Formation (Upper Miocene, Tp) - Interbedded sandstone, siltstone, and shale of the Puente Formation crop out extensively in the Elysian and Repetto Hills and flank both sides of the Glendale Narrows. The formation is subdivided in figure 3 on the basis of the relative abundance of siltstone (Tpsl), sandstone (Tpss), shale (Tpsh), or diatomaceous shale and diatomite (Tpds). Poorly cemented siltstone and finegrained sandstone, along with diatomaceous shale, occur primarily in the uppermost part of the formation, with wellcemented sandstone common below. As mapped by Lamar (1970) and shown in figure 4, the dominantly sandy Tpss underlies the Glendale Narrows and the proposed El Pueblo Lake, with Tpsl occurring south of borehole 2773J. However, borehole logs that penetrate Tpss in the Glendale Narrows region typically describe the Puente Formation as fine-grained. This apparent discrepancy could be due in part to the fact that the boreholes are largely penetrating shaly interbeds within Tpss, or may result from the relatively poor quality and generalized nature of most of the available borehole logs. Sedimentary features within the Puente indicate that deposition of this unit was dominantly by turbidity currents and that the lower part of the Puente Formation in the Elysian and Repetto Hills probably constitutes a lobe of the large Tarzana submarine fan complex identified from exposures on the north slope of the Santa Monica Mountains (Lamar, 1970). The structure of the Puente Formation reflects both syn- and post-depositional uplift and arching of the unit to form the Elysian Park anticlinorium. The axis of the anticlinorium approximately parallels the NW-SE trend of the Glendale Narrows. In general, rocks to the south of the Glendale Narrows in the Elysian Hills dip moderately (about 30-50 ${ }^{\circ}$ ) to the SW whereas those in the Repetto Hills dip moderately to steeply (often $>50^{\circ}$ ) to the NE. Locally the structure, particularly in the NE, is overprinted by numerous sub-parallel small-scale folds and is broken up by faults.

Fernando Formation (Pliocene, Tf) - Massive, soft siltstone (Tfsl) and sandstone (Tfss; not shown) with minor conglomerate crop out along the southern margin of the Elysian Hills and may directly underlie the alluvium of the Los Angeles River flood plain just to the south of the geologic section in figure 4. Available lithologic and faunal data from the Fernando Formation suggest that the unit was deposited in a marine environment in water depths ranging from shallow to more than 4,000 feet (Lamar, 1970).

\section{Unconsolidated Deposits}

Compilation and analysis of geologic and agricultural soils maps, along with borehole log data, provide a means of subdividing the unconsolidated alluvial and colluvial deposits of the Glendale Narrows region into units that represent discrete aggradational sequences that were likely deposited as a result of significant climate change. The soils data also provide information on the lithologic character of the surface deposits of these sequences that can be used to delineate, in a generalized sense, the mixed lithologies contained within each sequence. In map view, the fluvial sequences are recognized as nested river terrace and flood plain deposits whose surface soils display more extensive weathering profiles with increasing age. Although these units can be readily identified in map view on the basis of their position and soils, correlation of the units in the subsurface is difficult given the existing data.

The best characteristic for identifying unit boundaries in the subsurface is evidence of an unconformity expressed as a buried soil at the top of each sequence. Unfortunately, descriptions from available borehole logs for the most part are not sufficiently detailed to identify these weathering profiles. Occasionally, sediment color is described in borehole logs, and in some cases reports of oxidized colors (reds or yellows) may be an indicator of a buried paleosol or zone of more intense weathering. Even if additional detailed logs were available, however, the likelihood is high that many or most of these weathering profiles would have been removed by erosion prior to deposition of subsequent sequences.

To aid in correlation, interpretations in figure 4 rely on the characteristic that the overall grain size of fluvial sequences typically fine upward from a relatively coarse basal deposit (generally a gravelly sand in the confluence area) to dominantly fine sand or silt at the top of the sequence. Sequence boundaries may therefore occur at the boundary between major fining-upward sediment packages that can be correlated over large distances. Such correlations are 
complicated in the Glendale Narrows area. For the most part, older aggradational sequences have been removed by erosion during periods of river down-cutting and lateral channel migration. Therefore, only remnants of older deposits, with limited lateral extent, are likely to remain. Considering the complexity of the fluvial depositional system and the limited extent and detail of the borehole log descriptions available, the subsurface correlation of depositional fluvial sequences in the interpretive geologic section should be considered reasonable, but somewhat speculative.

Lower to Middle Pleistocene Deposits (Qpt, Qp1) Two presumably Lower to Middle Pleistocene depositional sequences are distinguished at the ground surface by their geomorphology and their soil-weathering profiles.

Sequence Qpt occurs at the southern margin of the Elysian and Repetto Hills as brown to reddish-brown, gravelly, poorly sorted alluvial-terrace deposits whose original depositional surfaces have been heavily dissected by small drainages (Yerkes and others, 1977). Clayey soils of the Altamont Series are developed on these deposits and are evidence of considerable age. Sequence Qpt is not visible at the surface within the Glendale Narrows, but a poorly sorted, reddish-brown to yellow, bouldery deposit is encountered at depths below $100 \mathrm{ft}$, north of borehole 3959D. This deposit may be correlative to sequence Qpt. Although no direct geotechnical data have been obtained, the poor sorting and semiconsolidated nature of this unit suggests that it would be of high density (standard penetration blow counts $(\mathrm{N})$ greater than 30 within finer-grained facies), relatively low permeability, and a shear-wave velocity of between 2,000 to 2,600 ft/s (Fumal and Tinsley, 1985).

Sequence Qp1 is exposed primarily along the eastern margin of the Glendale Narrows where it is typically silty (Qp1f), suggesting that much of the preserved sequence was derived from local, small drainages in the Repetto Hills, rather than being deposited by the Los Angeles and/or Arroyo Seco Rivers. Soils of the Ramona Series, which have moderate to extensive weathering profiles, are typically developed on this unit. Within the subsurface (fig. 4), sediment correlated with sequence Qp1 occurs only north of the confluence. Along the river profile, the sequence is coarser, consisting primarily of a gravelly basal unit and overlying sand. As opposed to Qpt, this sequence is typically unconsolidated, but still fairly dense ( $\mathrm{N}$ greater than 30 ). Permeability is likely to be high in the gravelly facies and low in the silty ones. Average shear-wave velocities for similar deposits elsewhere in the Los Angeles region are typically 1,500 to $2,200 \mathrm{ft} / \mathrm{s}$ for the coarse-grained facies, and about 1,000 to 2,000 ft/s for the finer-grained parts of the sequence (Fumal and Tinsley, 1985).

Upper Pleistocene Deposits (Qp2) - Sequence Qp2 is exposed primarily to the north of the Glendale Narrows as a broad alluvial terrace. Typically sandy (Qp2m), most of the unit is mantled by soils of the Hanford Series or, where fine-grained (Qp2f), by the Yolo Clay Loam. In both soils, the weathering profile is weak to moderate. In the subsurface of the Glendale Narrows, the unit is about 50 to 65 feet thick, but thins to the south and is apparently absent south of borehole $2772 \mathrm{~L}$. The geotechnical character of this sequence is likely similar to that of sequence Qp1.

\section{Lower to Middle or Undifferentiated Holocene} Deposits (Qh1, Qla) - Sequence Qh1 is the most extensive map unit in the lowland areas and occurs as a broad alluvial plain that extends from the Glendale Narrows out across the coastal plain. Soils developed on this unit belong to the Hanford Series where sandy (Qh1m) and to the Chino Series where fine grained (Qh1f). The weathering profiles of these soils are weakly developed. Sequence Qh1 likely represents a major episode of Early to Middle Holocene river aggradation in response to the most recent glacial-to-interglacial transition that occurred at the end of the Pleistocene. Although laterally extensive, it rarely exceeds $50 \mathrm{ft}$ in thickness within the Glendale Narrows. Dominantly sandy, the sequence is likely highly permeable in most regions, and loose to medium dense ( $\mathrm{N}$ less than 30). Average shear-wave velocities in similar materials in the Los Angeles region range from 500 to $850 \mathrm{ft} / \mathrm{s}$ in the fine-grained facies, to 1,000 to $1,200 \mathrm{ft} / \mathrm{s}$ in the coarse sand and gravelly zones (Fumal and Tinsley, 1985).

Qla, as mapped by Lamar (1970), is a landslide deposit approximately $650 \mathrm{ft}$ wide that occurs on the steep northeast flank of the Elysian Hills adjacent to the Los Angeles River just to the north of the confluence. The slide consists of Puente Formation rubble that likely failed from oversteepening of the slope owing to erosion from the Los Angeles River. Movement along the Elysian Park Fault of Lamar (1970), which projects beneath the slide debris, could also have contributed to slope instability by weakening the Puente Formation locally. This slide was last active in 1937 when its movement blocked Riverside Drive. It is plausible that grading activities along Riverside Drive may have contributed to the 1937 slide activity (Lamar, 1970).

Upper Holocene Deposits (Qh2) - Sandy (Qh2m) deposits that occur adjacent to the active channel of the Los Angeles River (predominantly to the west of the channel) and within the modern Los Angeles River flood plain reflect intermittent aggradational episodes within the Glendale Narrows area as a result of storm-related floods within the late Holocene. This unit is thin (less than $20 \mathrm{ft}$ ), and mantled by soils of the Tujunga Series, which exhibit extremely weak weathering profiles. Fine-grained Qh2f deposits typically occur as thin colluvial aprons of eroded Puente Formation at the base of hill slopes. Comparable materials within the Los Angeles region are typically very loose ( $\mathrm{N}$ less than 15 ), permeable except where very fine grained, and typically have low shear-wave velocities (less than about $650 \mathrm{ft} / \mathrm{s}$, Fumal and Tinsley, 1985).

Historical Deposits (Qhac, af) - Qhac represents aggradation and reworking of sediment within the active Los Angeles River and Arroyo Seco channels. The boundaries of the active channel (fig. 3) extend beyond the current river channels to include areas where the rivers have been known to migrate during the last century before channelization. These deposits typically consist of coarse sand and gravel and 
have virtually non-existent weathering profiles. Geotechnical properties of Qhac are likely similar to that of Qh2. The "deposit" identified as "af" consists of manmade fill, as much as $20 \mathrm{ft}$ thick, placed for flood control levee construction and as highway and road fill. The specific physical properties of these fill materials are presently unknown.

\section{Geologic Structures}

The dominant geologic structure in the confluence area is the Elysian Park Anticlinorium, a NW-trending arch that has uplifted the Elysian and Repetto Hills. In addition to folding of the Upper Miocene Puente Formation and Pliocene Fernando Formation, Lamar (1970) notes that the absence of Topanga Formation at the crest of the fold indicates an episode of pre-Puente deformation as well. The geologic section (fig. 4) illustrates the arch in the Puente bedrock surface below the Quaternary alluvial fill. The bedrock surface rises from north to south, from an altitude of approximately $160 \mathrm{ft}$ in the north to greater than $260 \mathrm{ft}$ beneath the proposed Confluence Park, and then falls slightly to approximately $230 \mathrm{ft}$ at the south end of the section. As presently interpreted, the Pleistocene alluvial sequences are shown to thin and eventually pinch out from north to south such that only the Holocene sequence rests atop the Puente in the vicinity of the proposed Confluence Park. These relations indicate that the deformation that is producing this fold has continued to be active through at least the Pleistocene epoch.

Recent evaluations of the geologic structure of the Los Angeles Basin following the 1987 Whittier Narrows earthquake (Davis and Namson, 1989; Shaw and Suppe, 1996; Shaw and Shearer, 1999; Shaw and others, 2000) and of small-scale folds in the Repetto, Merced, and Puente Hills (Oskin and others, 2000) have indicated that the broad fold belt that borders the northern and eastern Los Angeles Basin is still active and is the surface expression of movement on a series of buried (blind) thrust faults. These faults are thought to be capable of producing damaging earthquakes, such as the 1987 Whittier Narrows and 1994 Northridge events. Although there is considerable uncertainty in estimates of the geometry and activity of these faults, recent research proposes the existence of two stacked blind thrust faults that lie directly beneath the Glendale Narrows, including beneath the proposed Confluence Park area (Oskin and others, 2000). The shallowest of these is designated the Upper Elysian Park Thrust. This fault (not to be confused with the surface fault trace designated by Lamar (1970) as the Elysian Park Fault; see fig. 3) is modeled as a $50^{\circ}$ NE-dipping fault buried between 2 and 9 miles deep and with an inferred rupture area of about $100 \mathrm{mi}^{2}$. It is thought to be capable of producing a maximum M6.4 earthquake (California Geological Survey, 2002). The approximate surface projection of the tip of this fault as modeled by Oskin and others (2000) is shown in figure 3. Beneath the Upper Elysian Park Thrust within the study area is another inferred fault, the Puente Hills Thrust (fig. 1), which has been proposed to be the source of the 1987 Whittier
Narrows earthquake (Shaw and others, 2000). This fault lies beneath the entire confluence area and dips to the north more shallowly $\left(25^{\circ}\right)$ than does the Upper Elysian Park Thrust. It is also considerably larger, having an inferred surface area of more than $300 \mathrm{mi}^{2}$ (fig. 1). The segment of the Puente Hills Thrust beneath the confluence area is inferred to be capable of producing an earthquake as large as M7.1 (California Geological Survey, 2002).

The confluence also lies near the intersection of two major high-angle basin-bounding fault systems that do show clear expression at the ground surface. The Santa Monica Fault system trends E-NE and bounds the southern margin of the Santa Monica Mountains (fig. 1). The Whittier Fault system is a NW-SE trending zone that runs through the Puente Hills to the southeast and then splits into several NW-SE fault strands that project northwestward toward the confluence area. Several strands of these fault systems are considered to be active and capable of producing moderate to large earthquakes, on the basis of their geomorphology and fault length. The closest of these to the confluence area is the Hollywood Fault, part of the Santa Monica Fault system; the fault's easternmost end can be seen in the northwest corner of figure 3. The Hollywood Fault is an E-NE striking high-angle $\left(70^{\circ} \mathrm{N}\right.$ dip) fault that bounds the southern margin of the Santa Monica Mountains and has a minimum of $6,000 \mathrm{ft}$ of vertical separation, up on the north (Lamar, 1970). Left-lateral strike-slip motion also is likely, given the fault's geometry and orientation, but the relative amount of left-lateral movement of the fault is unknown. Recent evaluations of the Hollywood Fault suggest that it is capable of producing a maximum M6.4 earthquake (California Geological Survey, 2002). To the east of the confluence area and approximately on trend with the Hollywood Fault, but separated from it by the Repetto Hills, is the E-NE striking high-angle $\left(75^{\circ} \mathrm{N}\right.$ dip) Raymond Fault (fig. 1). This fault is clearly expressed topographically and shows evidence of both left-lateral strike-slip as well as reverse motion. The Raymond Fault is inferred to be capable of producing a maximum M6.5 earthquake (California Geological Survey, 2002).

The northern end of the Whittier Fault occurs more than 10 miles to the SE of the confluence area, within the Puente Hills. It is an active, NW-SE striking right-lateral oblique fault whose fault parameters are fairly well constrained (Rockwell and others, 1990; Gath and others, 1992). It is presumed to be capable of producing a maximum M6.8 earthquake (California Geological Survey, 2002). Northwest of the Puente Hills, the Whittier fault appears to split into several NW-SE trending fault strands that project beneath the alluvium of the San Gabriel Valley toward the confluence area (Woodford and others, 1954; Kundert, 1955). Within the Elysian and Repetto Hills area, Lamar (1970) has mapped an 5-mile-wide complex zone of NW-striking faults and NE-striking conjugate faults in bedrock that he infers may represent the NW continuation of the Whittier fault system. One of these faults, the Elysian Park Fault (Lamar, 1970, again, not to be confused with the Upper Elysian Park Thrust of Oskin, 2000), is exposed in Elysian Park along the NE flank of the Elysian Hills. This 
fault projects beneath the Glendale Narrows immediately to the north of the confluence (fig. 3). Lamar cites stratigraphic relations within the Elysian Park area that suggest that this fault is pre-Pliocene in age, with a maximum vertical separation of about $2,000 \mathrm{ft}$.

There appears to be a fairly abrupt vertical step in the surface of the Puente Formation near the projection of the Elysian Park Fault beneath the Glendale Narrows (fig. 4). This step (down to the north) is consistent with inferred motion of the Elysian Park fault and is also associated with an apparent pinch-out of sequence Qp1 and abrupt southward thinning of sequence Qp2. If movement on the Elysian Park Fault produced these relations, this implies that the fault was at least nominally active during the Pleistocene, and therefore may still be active today. Lamar (1970) also mapped two other unnamed NW and NE-trending faults in the Elysian Hills that have been projected beneath the Los Angeles River by Yerkes and others, (1977). These fault projections also appear to be nearly coincident with relative changes in bedrock altitude beneath the alluvium, as well as associated disruption of the Quaternary strata. One of these faults projects across the Los Angeles River directly beneath the proposed location of Confluence Park. It should be pointed out that current control on the bedrock topography is sufficiently coarse, and therefore, the inferred bedrock "steps" may not be nearly as abrupt as shown in figure 4 . Instead, the bedrock steps may not be fault related at all, but merely small-scale variations in the bedrock topography most likely associated with differential erosion. Likewise, the inferred stratigraphic disruptions associated with these possible fault zones also are speculative, given the overall poor quality of the available borehole logs. Nonetheless, the proximity of the mapped faults to these apparent changes in bedrock altitude leads to a reasonable hypothesis that the bedrock altitude changes may be fault related. The geologic section in figure 4 reflects this possibility, as drawn; however, additional information is clearly needed to test this interpretation as well as other possible interpretations of these structures.

If, as shown in figure 4, the faults inferred in the geologic section indeed have moved during the Quaternary, it is likely that they represent old zones of weakness in the bedrock that are now accommodating localized stresses that result from continued growth of the Elysian Park Anticlinorium, and are probably not independent seismic sources. These faults might therefore represent sympathetic structures that could move small amounts in concert with earthquakes on the underlying blind thrusts.

\section{Geological Issues}

Future development of Confluence Park ideally will incorporate in its design an understanding of the potential geologic hazards, including the potential for any such development to exacerbate those hazards, thus increasing the risk of economic loss to the neighboring community.
The following section lists possible geologic hazards that should be considered for the Confluence Park or similar types of projects, their likely impacts with respect to the current Confluence Park proposal, and the kinds of studies or tasks that might be conducted to better address these issues.

\section{Surface Faulting}

\section{Effects}

A localized, but potentially severe, impact of earthquakes on the urban environment is the potential for surface faulting. Surface faulting occurs when movement along a fault breaks through to the surface, resulting in permanent ground deformation. Most commonly, surface faulting occurs suddenly during an earthquake, but it can also occur slowly as a result of fault creep. The amount of displacement depends on the magnitude of the earthquake or creep event and on the location along the fault. For earthquakes in California, observed displacements have ranged from a fraction of an inch to more than $20 \mathrm{ft}$. Needless to say, fault displacements of more than a few inches can be devastating to certain kinds of structures. Fortunately, fault rupture almost always occurs along pre-existing faults; therefore, it is relatively easy to mitigate this hazard by keeping critical structures off known fault zones. In the State of California, the Alquist-Priolo Earthquake Fault Zoning Act of 1972 was passed to prevent the construction of buildings used for human occupancy on the surface trace of active faults. This Act requires the State Geologist to define regulatory zones around the traces of faults that have evidence for movement within the last 11,000 years and to issue maps of these zones, which are then used by local agencies to regulate development projects within the zone.

The risk that surface faulting could affect the Confluence Park development appears to be very low. An Alquist-Priolo zone has been identified along the Raymond Fault several miles NE of the confluence (fig. 1), but no zones are currently defined near the proposed Confluence Park. Nevertheless, given the quality and paucity of available information, the potential for surface faulting probably should be investigated further. If surface faulting were to occur when the temporary lake was present, resulting damage to the concrete channel walls or the dams themselves could promote a rapid loss of lake water into the ground or overland, potentially causing negative environmental impacts and/or damage to downstream areas. Rapid movement of water and possible erosion behind the channel walls could also exacerbate damage to the channel lining and cause localized ground failure or collapse of lining structures. Whether the lake was present or not, important park facilities, such as the dam control house and the inflatable dams might also be significantly damaged. As noted previously, there are several mapped fault zones that apparently project beneath or near to Confluence Park (figs. 3 and 4), and Holocene activity on these structures, while unlikely, cannot be entirely ruled out. Even if these faults were active, fault displacements would likely be small 
owing to their probable relation to folding of the Elysian Park Anticlinorium.

\section{Potential tasks}

1. Determine whether faults shown in figure 4 beneath the confluence area in fact displace the Puente Formation and disrupt Quaternary strata. To do this it would be necessary to conduct a shallow, high-resolution seismic reflection line to image the bedrock/alluvium interface. Such an effort would pinpoint the location of likely faults for possible further investigation.

2. If surface faulting within the confluence area appears possible based on the above investigation, the faults could be presumed to be active and their locations then accounted for in determining the placement of critical facilities at Confluence Park.

3. If design options require that potential faults interpreted from the seismic line be further verified, or that the recency or amount of fault displacement be known, it is possible to conduct trenching or borehole investigations to determine the recency and frequency of fault activity, and the amount of fault movement per slip event. These parameters can then be used to estimate the likelihood and magnitude for future displacement for use in facilities design.

\section{Earthquake Ground Motions}

\section{Effects}

By far the most significant hazard from earthquakes is the strong ground motions generated. Earthquake ground motions impart a lateral load on structures, and may cause structural damage or collapse if the structures are not appropriately engineered. Although no location in the Los Angeles region is safe from the threat of damaging levels of earthquake ground motion, the confluence region is at particularly high risk for two reasons. First, several seismogenic faults, potentially capable of producing earthquakes of M6 or greater, are known or are inferred to occur within a 12-mile radius. These include the Hollywood, Raymond, Whittier, Puente Hills thrust, and Upper Elysian Park Faults. Strong ground motions from earthquakes on these faults would be expected in the confluence area given the proximity of these seismic sources. Second, the confluence region is underlain by a relatively thin accumulation of alluvial sediment characterized by a low-shear wave velocity, above consolidated rock with a significantly higher shear-wave velocity. The shear-wave velocity contrast between the bedrock and overlying alluvial units would amplify ground motions at frequencies that depend on the thickness of the lower velocity material.
Over the last decade or so, significant effort has been made by the USGS and by the California Geological Survey (CGS) to develop seismic hazard maps that incorporate such factors as seismic source location, ground motion attenuation, and local site amplification to estimate the shaking hazard from earthquakes in California. These new maps are probabilistic: they take into consideration uncertainties in the size and location of earthquakes and the resulting ground motions that can affect a particular site. Seismic hazards maps and calculations by the California Geological Survey (2002) represent the shaking hazard in terms of a 10-percent probability of exceeding a certain ground motion during a 50year time period, which is a typical design level for buildings in high seismic areas. This value represents an annual probability of 1 in 475 of being exceeded each year, and takes into account all known nearby sources, their presumed level of activity (likely magnitude and rates of recurrence), and generalized site amplification effects, along with inherent uncertainties. Based on the California Geological Survey model (2002), the predicted peak ground acceleration with a 10 -percent probability of exceedence in the confluence region, is $0.57 \mathrm{~g}$. This value approaches some of the largest values recorded in the northern San Fernando Valley during the 1994 Northridge earthquake. Similar analyses can also be done for anticipated scenario earthquakes.

Shown in figure 5 is the median (50-percent probability of exceedence) predicted peak ground acceleration for a M7.1 earthquake on the Puente Hills thrust (OpenSHA Model, 02/02/04). This structure would likely produce the highest ground motions of any nearby fault. The figure clearly shows the amplification effect resulting from the alluvium within the Glendale Narrows. At the confluence, the median peak ground acceleration is predicted to be greater than $0.7 \mathrm{~g}$ - considerably higher than the probabilistic value because this approach presumes that the Puente Hills earthquake has actually occurred. The 10 percent probability of exceedence for this earthquake is even higher still (greater than $1.1 \mathrm{~g}$ ). With the exception of the site effects, there is little evidence of ground-motion variability because the fault plane lies completely beneath the map area and therefore all points on the map are approximately the same distance from the seismic source.

Predicted ground motions for a M6.4 earthquake on the Upper Elysian Park fault described by Oskin and others (2000) are shown in figure 6. The ground motions from this earthquake at the confluence are predicted to be less than those for the Puente Hills thrust (median peak ground acceleration of approximately $0.42 \mathrm{~g}$ ) because of the lesser earthquake magnitude, and because modeled ground motions decrease southwest of the fault owing to attenuation.

One unique aspect of the ground motion issue relevant to Confluence Park and El Pueblo Lake is the possibility of a seiche being created in the lake from an earthquake. A seiche is a free or standing wave oscillation of a body of water, 


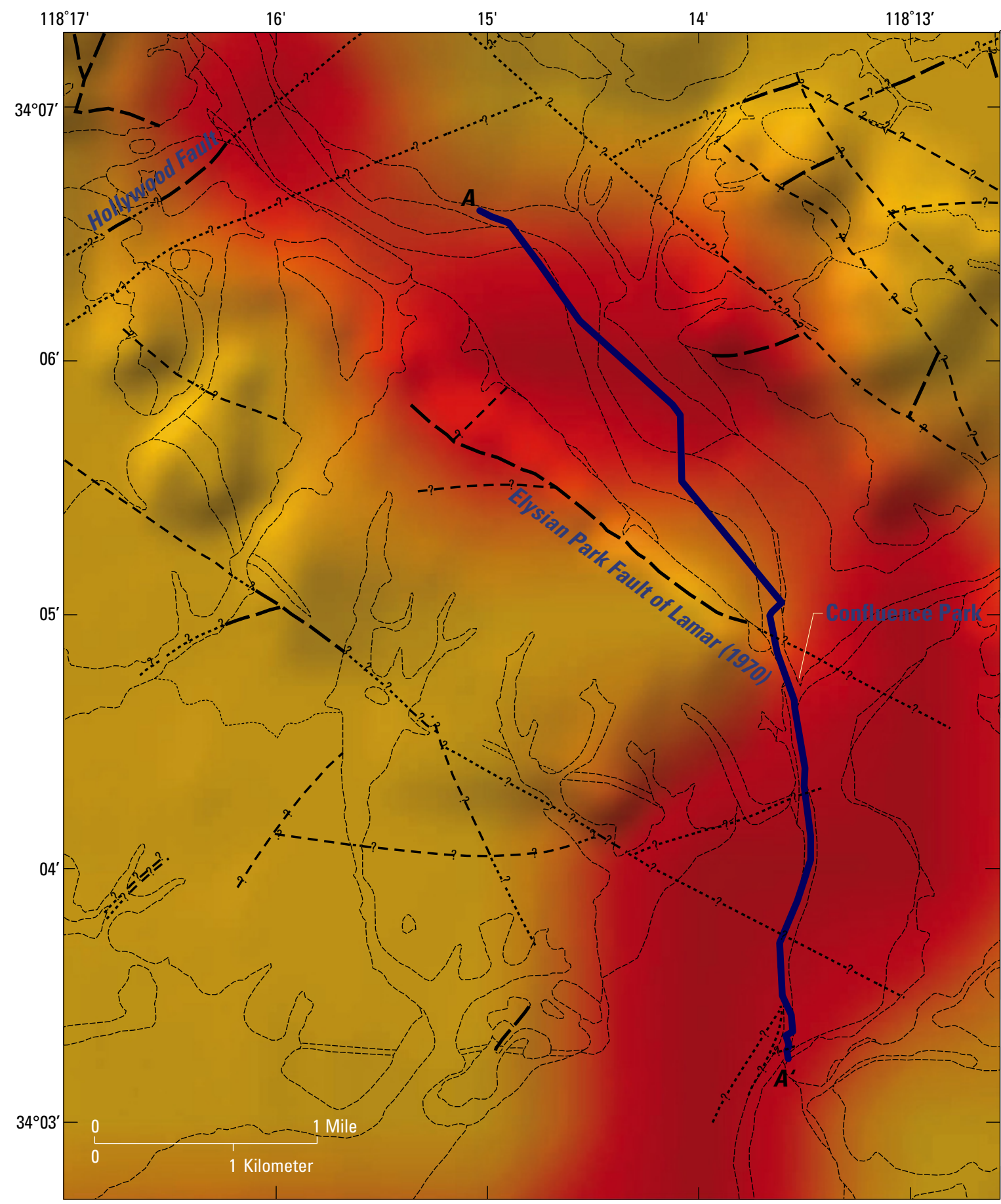

EXPLANATION

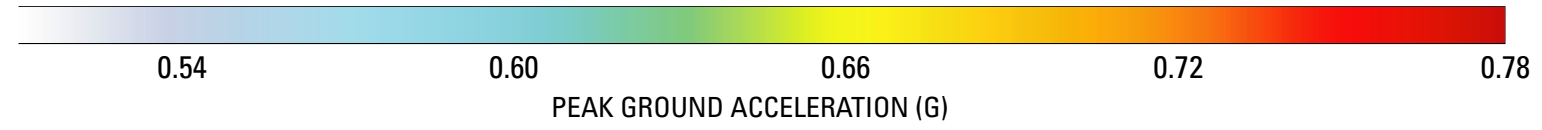

$A \longrightarrow A^{\prime}$ Line of geologic section (figure 4)

Contact, approx. located

Fault, queried

Fault, concealed

Fault, queried, concealed

- Fault, approximately located

Figure 5. Predicted median peak ground acceleration in the confluence area from a scenario M7.1 earthquake on the Los Angeles segment of the Puente Hills Thrust. 

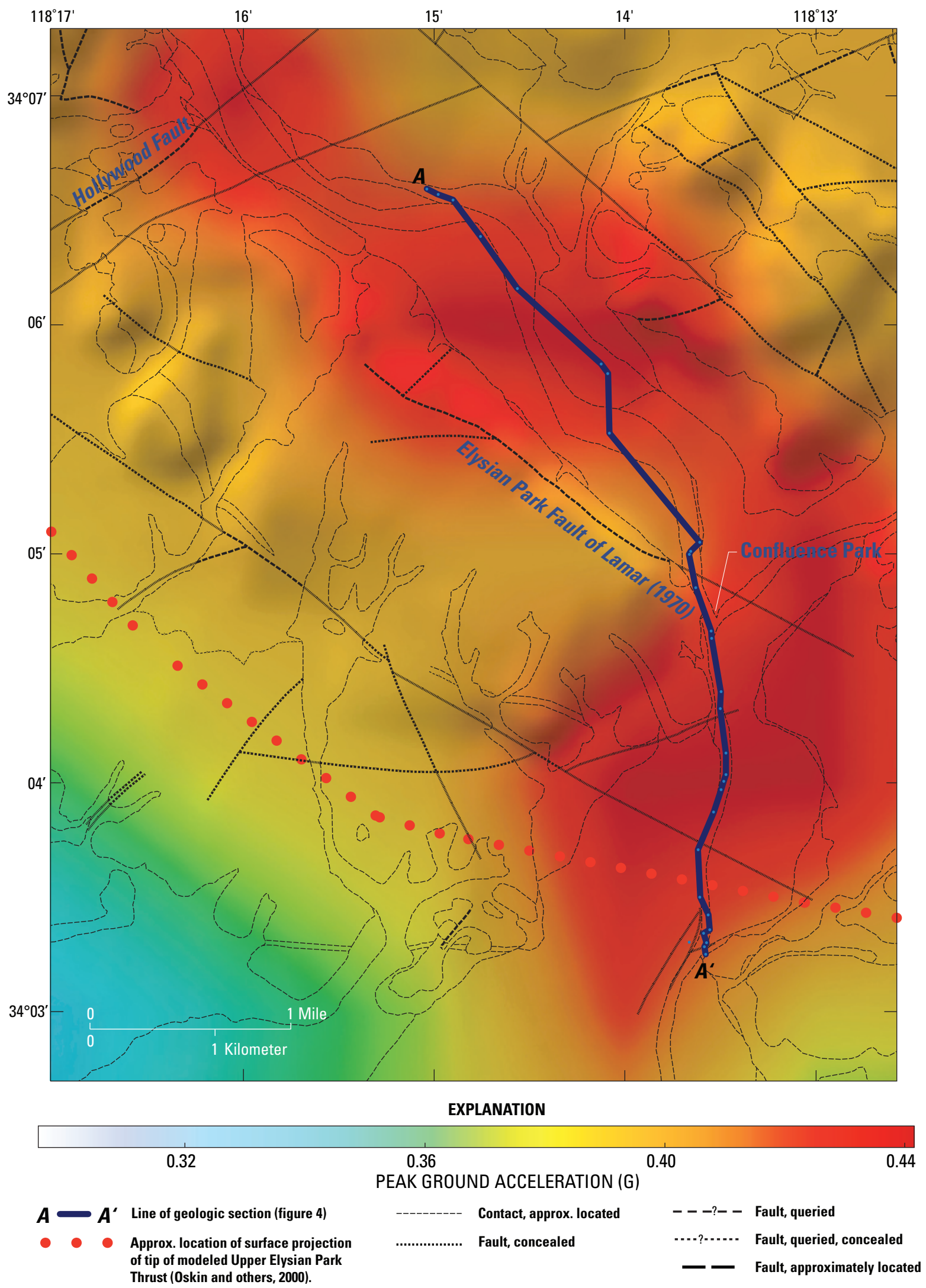

Figure 6. Predicted median peak ground acceleration in the confluence area from a scenario M6.4 earthquake on the Upper Elysian Park Thrust. 
whose period of oscillation is determined by the resonant characteristics of the containing basin (Bates and Jackson, 1980, p. 568). Depending on the frequency content of the input ground motions, oscillation of the lake surface might prove significant enough to overtop the portable dams. Also, wave oscillation would likely impart significant dynamic lateral loads to the portable dam structures. If the anchors for the dams are not sufficiently strong to withstand these loads, damage to the dams could occur and cause an unanticipated release of lake water downstream.

\section{Potential tasks}

1. Derive design-earthquake ground motions using industry-standard techniques, and design buildings and engineering works to withstand these anticipated ground motions.

2. Determine a shear-wave velocity profile for the confluence area to a depth of at least 100 feet to better model near-surface site amplification effects. Shearwave measurements could be made in a borehole drilled for other purposes (such as a nearby groundwater monitoring well).

3. Model the proposed El Pueblo Lake to determine the likelihood of a seiche developing in the structure during an earthquake. Evaluate the design of the clamps that anchor the portable dams in place to determine if they could withstand lateral loads imparted by the oscillations.

\section{Liquefaction}

\section{Effects}

Liquefaction is a secondary effect of earthquake ground motion and has historically been a major cause of earthquake damage in southern California (California Geological Survey, 1998). Liquefaction is a process by which water-saturated, granular sediment (such as sand) transforms into a liquefied state and fails owing to increased pore-water pressures from strong ground shaking (Youd, 1973). The geologic and hydrologic conditions that favor the occurrence of liquefaction are fairly well understood, and susceptible environments can be delineated with reasonable precision. As a result of the Seismic Hazards Mapping Act of 1990, the California Geological Survey has begun producing maps that delineate liquefaction hazard zones. Within these regions, subsequent site-specific liquefaction analyses are required for certain kinds of developments. These liquefaction zones are intended to be conservative; they highlight areas of loose, generally sandy materials of historical or Holocene age, where ground water is thought to be sufficiently shallow (water table within
$40 \mathrm{ft}$ of the land surface), and where potential earthquake ground motions are expected to be sufficiently high to produce liquefaction (California Geological Survey, 1998). Because of inherent variability within the subsurface materials, it is improbable that all regions within a liquefaction zone are susceptible to failure. The California Geological Survey liquefaction hazard map for the confluence area is shown in figure 7. Virtually all of the Glendale Narrows, Arroyo Seco, and Los Angeles River flood plain areas are included in the State's liquefaction zone.

Insufficient information exists to perform a detailed or site-specific liquefaction hazard analysis for the confluence area, but a general assessment of the hazard can be made. As part of the construction of the geologic section in figure 4 , water-level measurements from borehole records were compiled to provide a snapshot of the ground-water conditions in the confluence area. These data reflect water levels reported when the holes were drilled, and most of them were drilled several decades ago. Nevertheless, these data suggest a ground-water surface with a gentle southward gradient. From the Pasadena Freeway northward, these data show that the lowermost portion of Holocene sequence Qh1 is largely saturated at depths of approximately $40 \mathrm{ft}$ or less, consistent with a fairly high potential for liquefaction. South of the Pasadena Freeway, however, and in the area of Confluence Park, the ground-water levels lie at or below the base of Qh1. Given that the underlying Pleistocene alluvium and Puente Formation are not likely to liquefy, the available information would suggest that the liquefaction hazard in the vicinity of Confluence Park is less than it is farther to the north. However, this interpretation needs to be corroborated with more detailed, up-to-date information on current water levels, and better details about the specific character of the deposits in the vicinity of Confluence Park.

One factor that needs to be considered in assessing the liquefaction potential of the confluence area is the degree to which the development of an intermittent lake may cause ground water to rise in areas adjacent to the lake. As present plans are for a shallow lake that only floods the lined portion of the Los Angeles River, the effect on ground-water levels would be minimal. If channel-lining removal is conducted on the Arroyo Seco, this may result in a slight rise in groundwater levels. If so, even a modest rise could significantly increase the liquefaction hazard near Confluence Park.

If liquefaction were to occur in the confluence area, the ground could fail in a number of ways. Common modes of ground failure from liquefaction include lateral spreading, flow failure, ground oscillation, and loss of bearing strength (Youd, 1978a,b). Flow failure is not a likely process in the confluence area because of the relatively low slope of land surface within the region. The most likely failure mechanism in the confluence area is lateral spreading, where gravitational forces plus inertial forces from the earthquake can cause masses of earth material to move several feet or more toward 


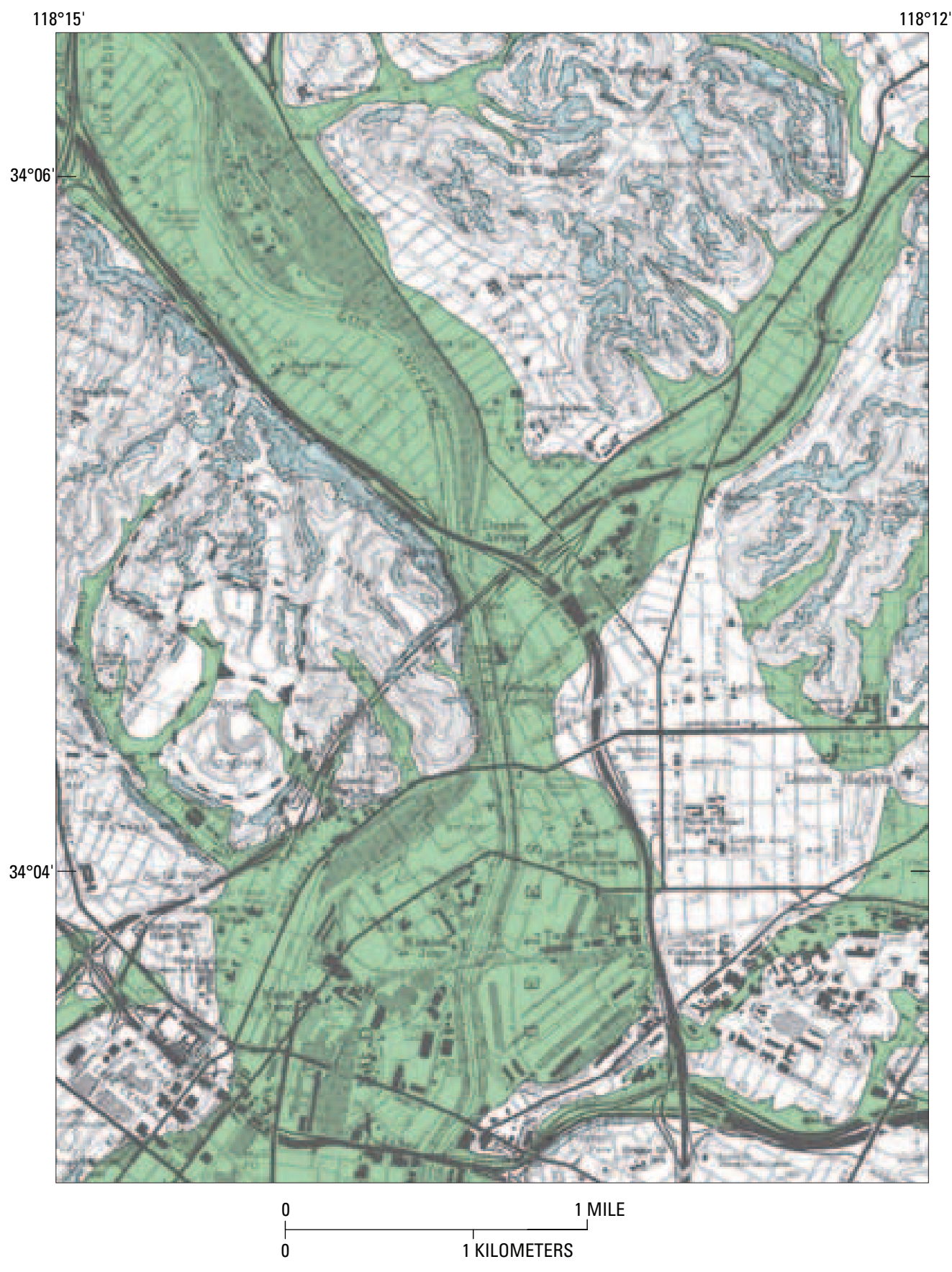

Figure 7. Liquefaction and landslide potential for the confluence area. Map is derived from a portion of the California Geological Survey Seismic Hazard Zone Map for the Los Angeles Quadrangle (1998). Green delineates areas of potential liquefaction, as determined by historical occurrences of liquefaction, or susceptible geological, geotechnical, and ground-water conditions. Light blue delineates areas of potential earthquake-induced landslides, as determined from the prior occurrence of landslide movement, or local topographic, geological, geotechnical, and subsurface conditions that indicate a potential for permanent ground displacements. a cut slope or free face. A plausible scenario might be the collapse of the banks of the Los Angeles River into its channel, causing significant damage to the channel lining as well as to any structures near the river bank. If the lake is full at the time, the bank failures could displace water from the lake and thereby cause overtopping of the dam, an unplanned discharge downstream, and local flooding, followed by a loss of lake water into the subsurface. Ground oscillations and bearing failure under structures could also occur, which typically results in localized ground settlement and building damage. 


\section{Potential tasks}

The threat of damage to Confluence Park facilities and the engineered channel linings from liquefaction is a plausible one, given current knowledge of the subsurface conditions. Furthermore, development of a lake could increase the hazard locally, potentially putting structures outside the Park at greater risk of damage. Unfortunately, existing information is not sufficient to determine if liquefaction is indeed likely to occur. Potential tasks to develop this information are as follows:

1. Conduct a detailed subsurface investigation of the confluence area to evaluate the liquefaction susceptibility of the underlying sediment. Such an investigation should involve the use of cone penetrometer soundings in addition to several geotechnical boreholes where samples can be collected for lab testing. Piezometers should also be installed to measure baseline water levels and to monitor both seasonal water-level fluctuations, as well as any water level change that may occur as a result of lake filling.

2. Perform liquefaction hazard analyses using the new data to assess the potential problem and as input in facilities design.

\section{Landsliding}

\section{Effects}

Landslides have historically been a major cause of damage to the built environment and can be triggered by storms and earthquakes (California Geological Survey, 1998). Landslides have destroyed or damaged homes and other structures, blocked transportation corridors, and damaged various types of lifelines and other infrastructure. Typically, areas most susceptible to landslides are on or adjacent to steep slopes and on or adjacent to existing landslide deposits, especially if the earth materials in these areas are composed of loose colluvial soils, or poorly cemented or highly fractured rock. Within the confluence region, geologic and terrain conditions favorable to landslides exist on steep slopes within the Elysian and Repetto Hills. Earthquake-triggered landslides also fall under the scope of the California Seismic Hazards Mapping Act of 1990. Figure 7 shows the location of these landslide-susceptible zones in the confluence area.

Earthquake-triggered landslides most typically fall under the classification of shallow soil slips or rock avalanches; rarely is the whole mass of a deep-seated landslide reactivated in earthquakes (Keefer, 1984). However, it has been observed worldwide in prior earthquakes that the steep scarps and toe areas of existing large landslides that formed from prior earth movements, are particularly susceptible to earthquakeinduced slope failure (California Geological Survey, 1998); therefore, areas having existing landslides are considered to be particularly vulnerable to renewed ground failure during future earthquakes.
As mentioned previously, one active landslide mass exists adjacent to the Los Angeles River channel on the steep northeast slope of the Elysian Hills between the Pasadena Freeway and Interstate 5. Lamar (1970) speculated that this slide formed as a result of oversteepening of the slope caused by erosion from the Los Angeles River channel. The Los Angeles River channel banks are now concrete-lined, and current Confluence Park development plans do not call for removal of the lining at this location. However, any future restoration plans that might involve channel-lining removal, such as in the Arroyo Seco or elsewhere, should take into account the possibility that such action may exacerbate a slope-failure hazard, especially along the northeast flank of the Elysian Hills. There is virtually no hazard from landslides in the vicinity of Confluence Park as this location is sufficiently removed from the hillslopes.

\section{Potential tasks}

To address the effects of channel-lining removal along the Arroyo Seco, slope stability analyses should be conducted where the current river channel lies near or adjacent to slopes with a gradient of 20 percent or greater.

\section{Reservoir-Induced Seismicity}

\section{Effects}

Several types of engineering developments are suspected, with varying amounts of evidence, to be capable of triggering earthquakes on a limited, localized scale (Simpson, 1976). The sizes of these triggered earthquakes range from moderately sized, damaging earthquakes down to micro-seismic emissions, which are only sensed by specialized instrumentation. Historically, the development of large reservoirs for power generation was the first type of engineering activity that significantly affected the seismicity of the earth's crust. The induced seismicity associated with such stress modifications was then recognized. The largest event of this type yet recorded was a 6.5-magnitude event (Richter scale) and this event was associated with the impoundment of a very large (deep) reservoir. It is thought that deep new reservoirs can trigger earthquakes because of a change in stress caused by the mass of the water in the reservoir, or more commonly by increased ground-water pore pressure that results in a decrease in the effective strength of the rock beneath the reservoir. Where reservoir-induced seismicity has been observed, the reservoirs involved have been deep to very deep (260 to $500 \mathrm{ft}$, Schwartz and others, 1996). Given that proposed creation of El Pueblo Lake will produce a structure no deeper than about $16 \mathrm{ft}$, and the lake will be completely lined in concrete, there is virtually no risk that the presence of such a shallow lake could trigger earthquakes.

\section{Potential tasks}

None. 


\section{Hydrology}

\section{Hydrologic overview of the study area}

\section{Hydrologic setting}

The headwaters of the Los Angeles River originate at the western end of the San Fernando Valley and are fed by several creeks which drain the surrounding Santa Monica, Santa Susana, and San Gabriel Mountains. The river passes through the Glendale Narrows, then flows across the coastal plain and empties in the Pacific Ocean via San Pedro Bay (fig. 1). The Arroyo Seco, a tributary to the Los Angeles River, originates in the San Gabriel Mountains, drains part of the Raymond Basin, and enters the Los Angeles River at the lower end of the Glendale Narrows. The Glendale Narrows links the inland upper ground-water basins to the lower coastal ground-water basins. Ground water in the Glendale Narrows primarily flows through the relatively shallow unconsolidated deposits shown in figure 3 and 4.

As mentioned in the Introduction, the hydrologic system has been greatly affected by urbanization throughout the development of the city. Both the Los Angeles River and the Arroyo Seco have been channelized for flood-control purposes. Upstream reservoirs have altered the natural flow regime. Flow throughout most of the year is now increasingly dominated by discharge from wastewater reclamation facilities, ground-water treatment facilities, and urban runoff. As a consequence, the quality of water in the river has been affected by these new sources.
Urbanization also has affected ground-water conditions. The source of ground water in the study area is from (1) underflow from upper, inland basins, (2) surface water (which is often a mixture of winter stormflow, treated wastewater, urban runoff, and treated ground water), and (3) direct infiltration of precipitation.

The unlined part of the Los Angeles River channel (see fig. 2) has historically been an area of natural ground-water discharge. Ground-water pumpage within the Glendale Narrows area is limited. Pumping occurs in the adjacent San Fernando Valley; pumping also occurs several miles downstream in the Central Basin (fig. 8).

\section{Hydrologic monitoring and modeling}

Surface-water and ground-water monitoring programs and modeling efforts of the study area have been implemented by several agencies. These are summarized below.

The location of established stream-gaging stations on the Los Angeles River and tributaries in the area is shown in figure 8 . There are a few active gages near the confluence area. The Los Angeles River just above the Arroyo Seco (USGS 11097500; also LACDPW site F57-CR), and the Arroyo Seco below Devils Gate Dam in the Raymond Basin (LACDPW site F277-R) are operated by the Los Angeles County Department of Public Works and were established in 1931 and 1942, respectively. A third site, the Arroyo Seco near Pasadena (USGS 11098000) has continuous flow data extending back to 1916 . The long-term records for these stations provide a basis for characterizing the flow regimes under historical and recent conditions. A quantitative analysis of the flow regimes

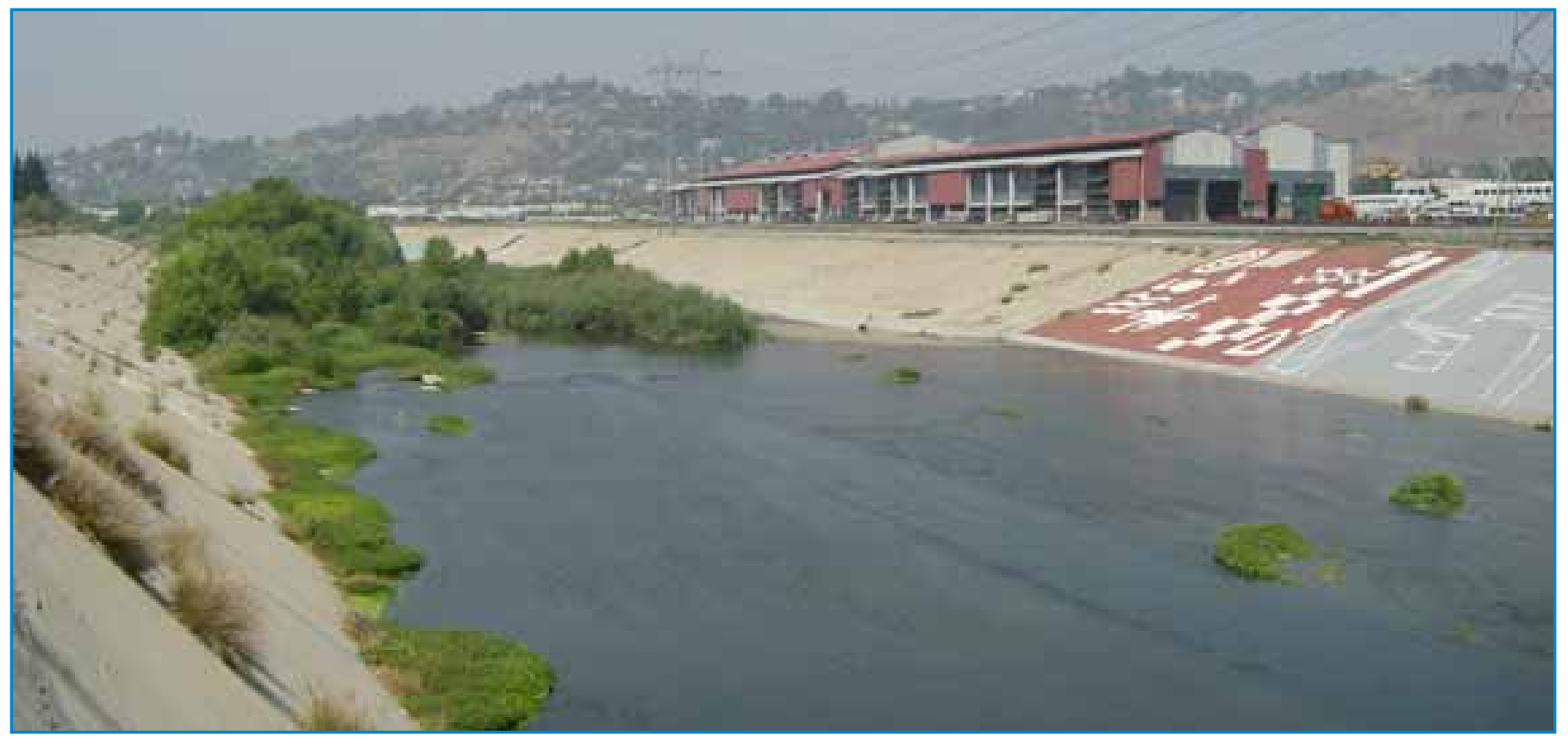

Upstream view near an unlined section of the Los Angeles River. (photograph by Dale Cox, U.S. Geological Survey) 


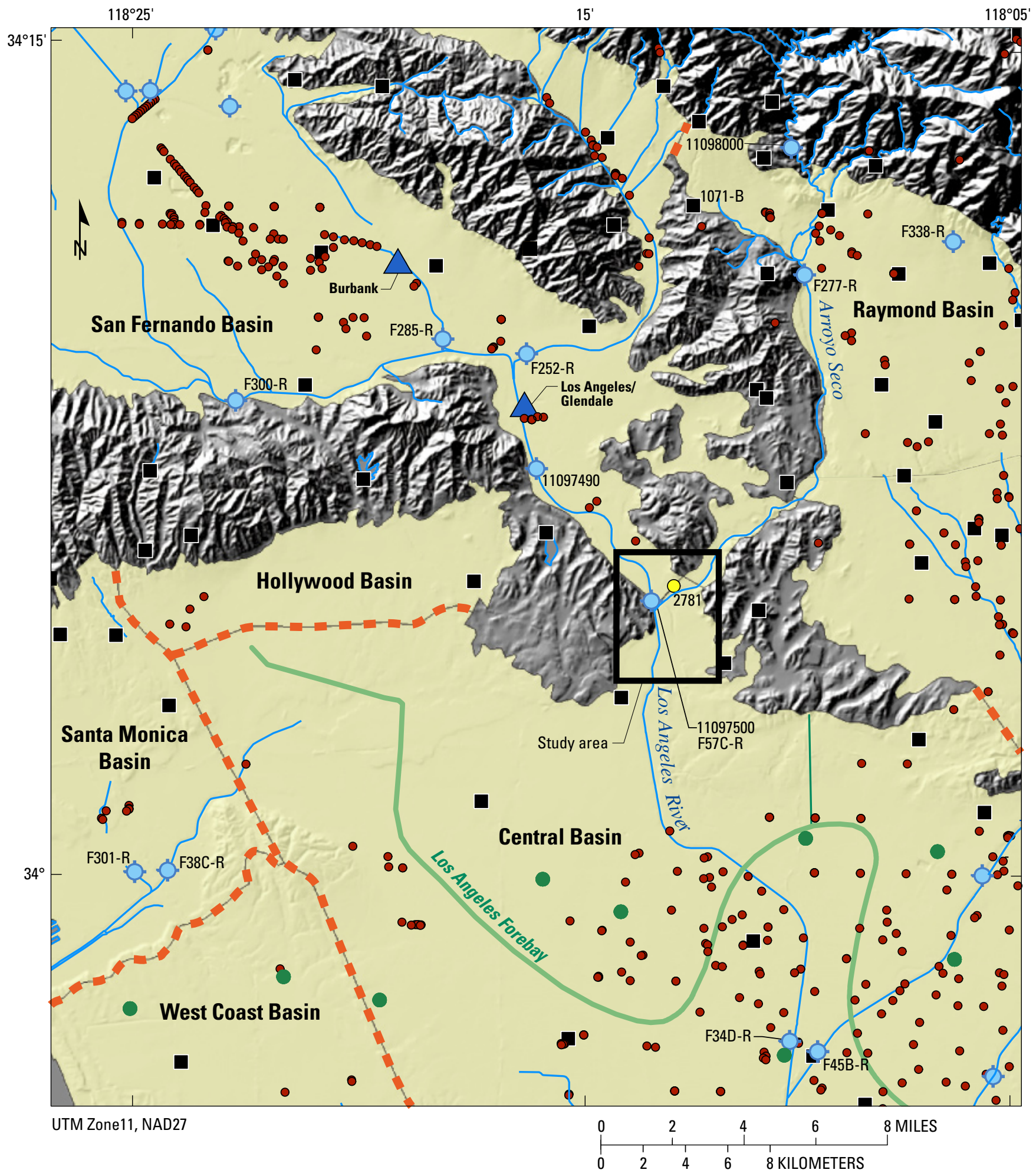

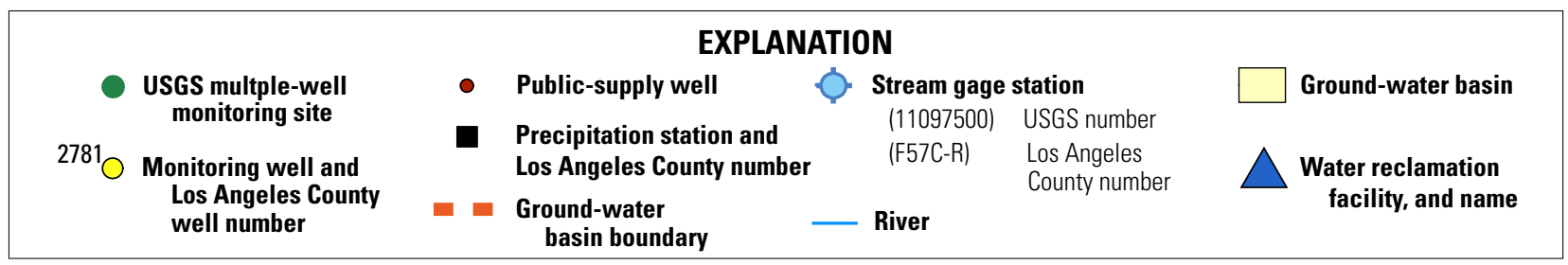

Figure 8. Location of precipitation stations, surface-water gaging stations, and ground-water wells in the study area and vicinity. 
is required to determine the design, feasibility, and operation of any inflatable dam.

Comprehensive, long-term monitoring of water-quality along the Los Angeles River has been limited. At two stations, USGS 11097500 (at Los Angeles) and USGS 11097490 (at Feliz Blvd.), monthly chemical data (nutrients, major ions, temperature, dissolved oxygen, and turbidity) were collected during the period 1966-73 and 1973-77, respectively.

Several agencies have water-quality monitoring programs for dischargers and municipal agencies to satisfy either State or Federal regulations, State of California Title 22, National Pollutant Discharge Elimination System (NPDES), or as part of Superfund cleanup requirements. The Los Angeles River watershed has impaired water quality in the middle and lower parts of the basin owing to runoff from dense clusters of commercial, industrial, residential, and other urban activities. The U.S. Environmental Protection Agency (USEPA) 303(d) list of impairments, due to point and nonpoint sources, includes the following: $\mathrm{pH}$, ammonia, selected metals, algae, coliform, trash, scum/foam, oil, selected pesticides, and selected volatile organic compounds (VOC).

Selected water-quality monitoring in the river and its tributaries is being conducted by the City and County of Los Angeles and other parties (Michael Mullin, City of Los Angeles, unpub. data, 2004). Status and trend monitoring involves regular sampling from 17 stations on the river and its tributaries for heavy metals and bacteria. In addition, there is extensive monitoring of discharge into the Los Angeles River from the three water reclamation plants (WRPs) - the Glendale, the Burbank (see fig. 8) and the Tillman (about 13 mi northwest) WRPs. Monitoring of effluent at these locations includes VOCs, pesticides, metals, nitrogen, and bacteria. A high proportion of inflow to the proposed El Pueblo Lake at the confluence would originate as discharge from these WRPs.

Measurements of depth to ground water in the study area are collected from a combination of observation wells, abandoned production wells, or shallow site-specific monitoring wells by the City of Los Angeles, Department of Water and Power, the Los Angeles County Department of Public Works, and other entities. Wells in the Glendale Narrows typically are perforated in shallow, unconsolidated deposits. Less is known about ground-water conditions (water levels and quality of water) in the deeper zones, as well as in the consolidated basement materials (see Tpss, fig. 4).

Computer models of varying scales have been constructed to simulate and quantify the movement of surface or ground water in the Los Angeles area. Larger-scale regional groundwater models have been developed for the San Fernando Valley (Patricia Kiechler, Upper Los Angeles River Area Watermaster Services, oral commun., 2004), the Raymond Basin (Anthony Zampiello, Raymond Basin Management Board, oral commun., 2004), and the Central and West Coast Basins (Reichard and others, 2003). Smaller-scale groundwater models focus on specific areas such as Taylor Yard (Miller Brooks Environmental, 2002). The Southern California Coastal Water Research Project (SCCWRP) is currently developing a watershed model for the Los Angeles River as part of a project studying the southern California coastal watershed (Southern California Coastal Water Research Project, 2004)

\section{Hydrological Issues}

\section{Surface-water hydraulics}

\section{Effects}

Operation of a temporary lake would affect the hydraulic regime of the Los Angeles River both upstream and downstream from the dam. However, as planned, El Pueblo Lake would not extend into the unlined part of the Los Angeles River, and the magnitude of the effects are likely to be small given the small volumes of water that would be impounded.

Information on non-winter flows in the Los Angeles River and the Arroyo Seco (shown in fig. 9-11) serve as examples of the types of analyses that could be undertaken. Figures 9 and 10 shows historical maximum daily flow values for the Los Angeles River above Arroyo Seco and for Arroyo Seco near Pasadena, respectively, for the months of May through September, which are the probable months in which the dam(s) and lake might be operational. Note that flow within the Los Angeles River is much greater than that of the Arroyo Seco.

Although median maximum daily values at the Los Angeles River above Arroyo Seco for these months are generally low-less than or equal to $58 \mathrm{ft}^{3} / \mathrm{s}$ for all selected months-significantly higher values are shown to occur in many years (fig. 9). For the Arroyo Seco near Pasadena, median maximum daily values are much lower than in the Los Angeles River, generally less than $6 \mathrm{ft}^{3} / \mathrm{s}$. Again, as in the Los Angeles River, there is considerable variability from year to year.

The number of days with flows exceeding $50 \mathrm{ft}^{3} / \mathrm{s}$ at the Los Angeles River above Arroyo Seco for the same period (May through September) during the year is shown in figure 11. Prior to about 1978 , there were generally very few "dry season" days in which daily flows exceeded $50 \mathrm{ft}^{3} / \mathrm{s}$. In recent years this flow rate is now exceeded most of the time. This is consistent with increasing contributions of effluent discharge from upstream wastewater treatment facilities and, to a lesser extent, contribution of urban runoff during non-winter periods.

Information presented in figures $9-11$ could be used for both the design and the operation of any temporary lake. 

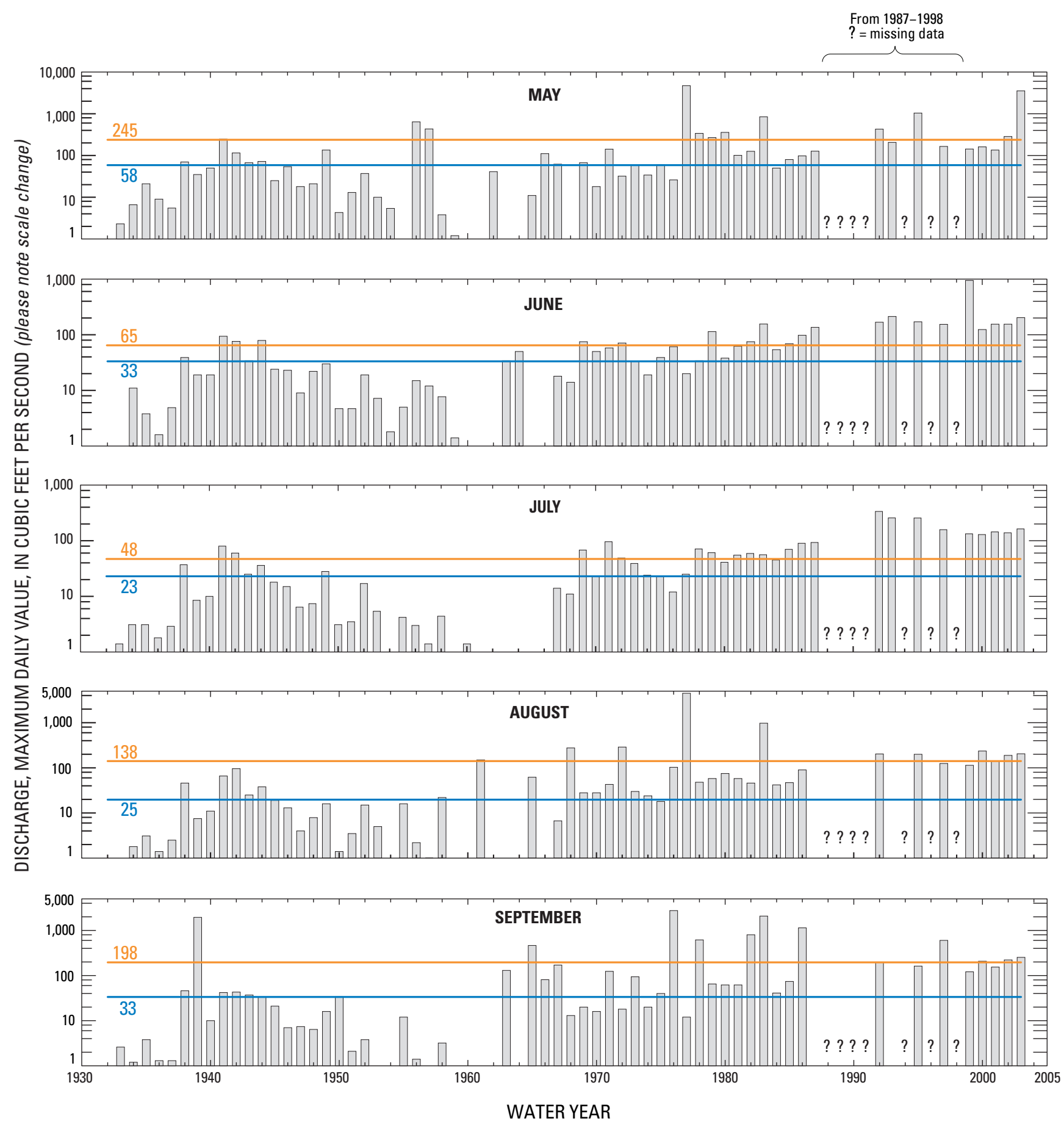

\section{EXPLANATION}

Mean _ Median

Figure 9. Historical maximum daily discharge at the Los Angeles River above Arroyo Seco (USGS 11097500, LACDPW F57C-R) for May through September, 1932-2003. 


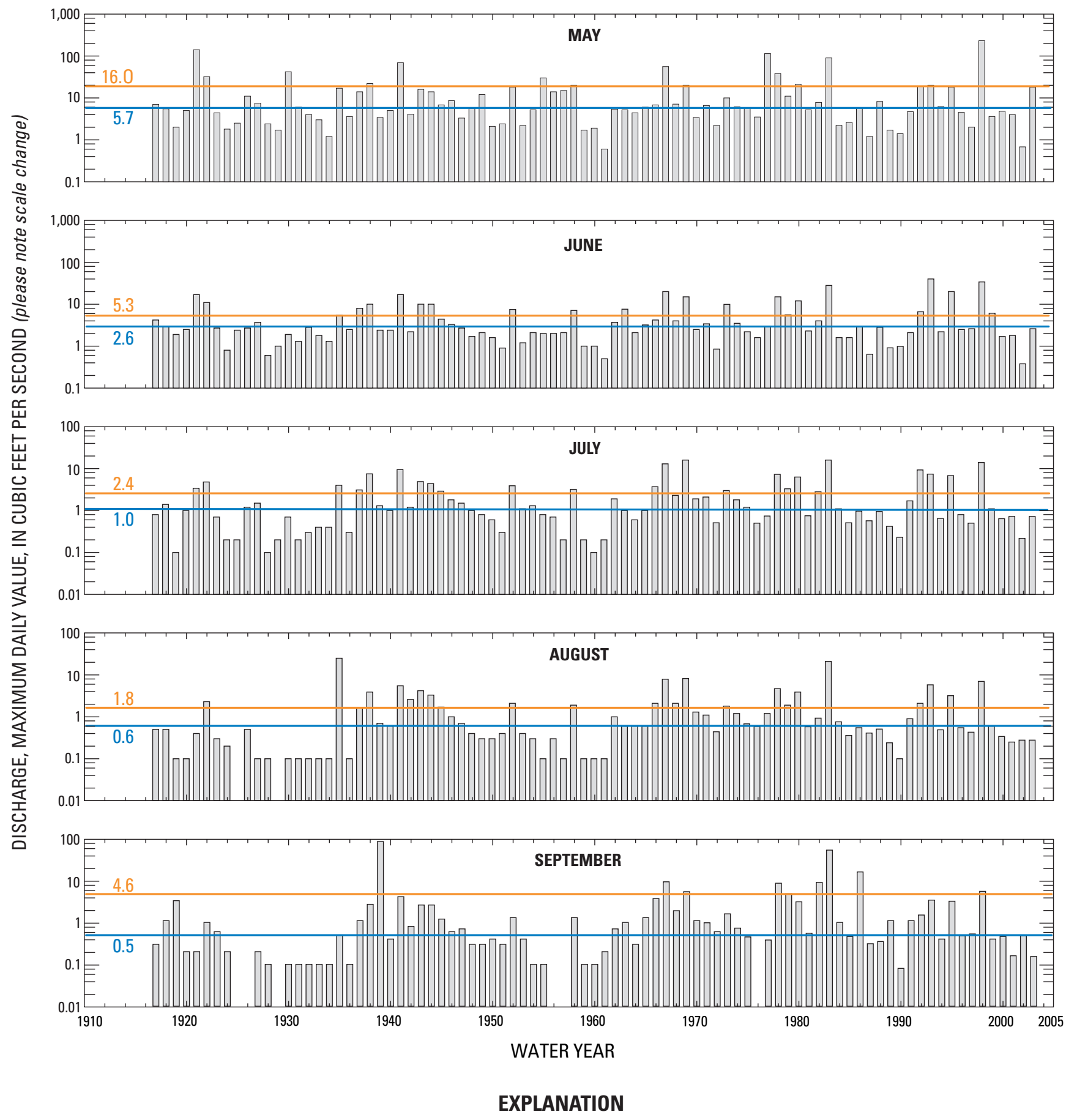

Mean — Median

Figure 10. Historical maximum daily discharge at Arroyo Seco near Pasadena (USGS 11098000) for May through September, 1917-2003. 


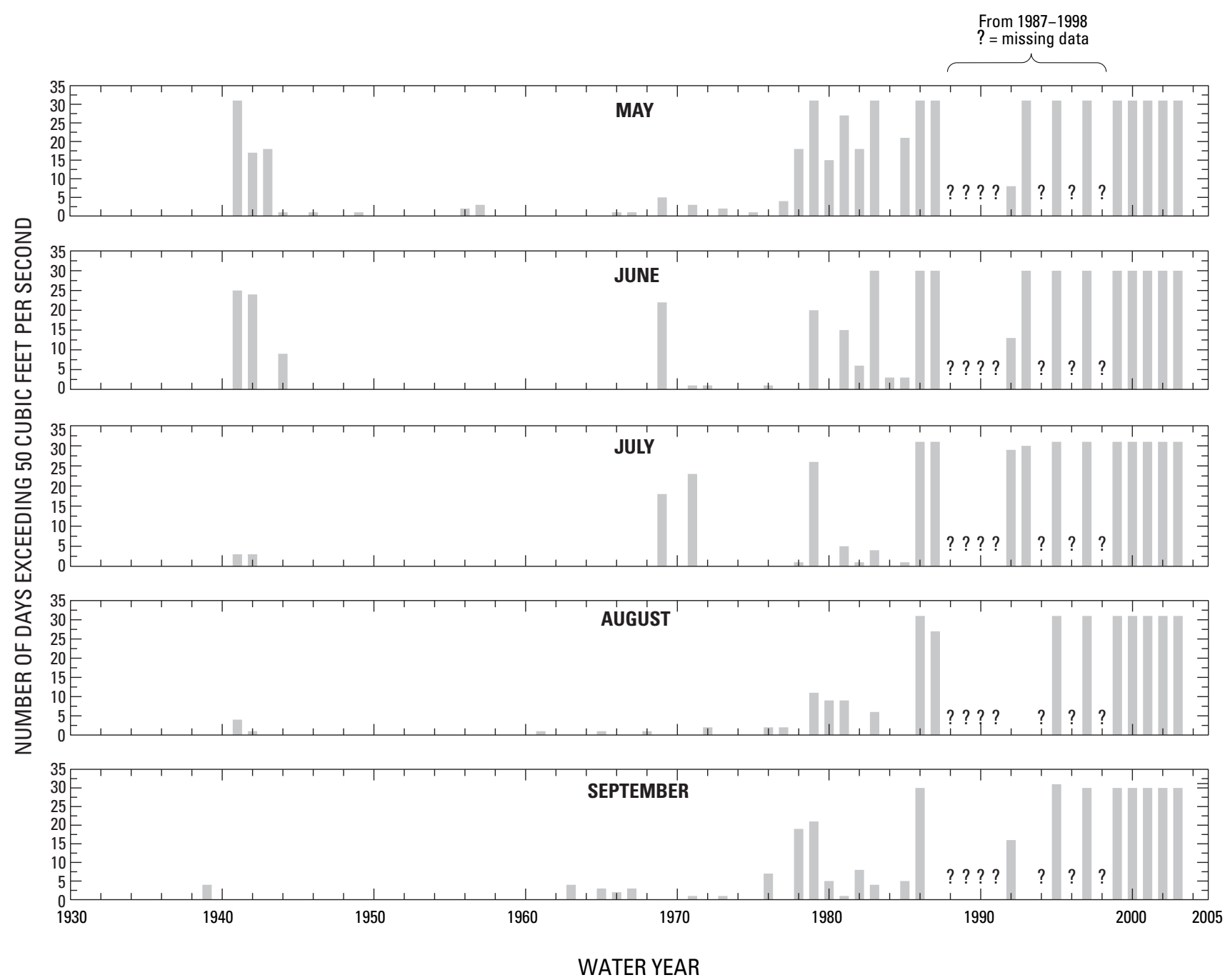

Figure 11. Number of days with flow exceeding 50 cubic feet per second at the Los Angeles River above Arroyo Seco (USGS 11097500, LACDPW F57C-R) for May through September 1932-2003. 
This type of information has relevance for likely downstream discharge and its measuremen, assessment of possible sediment load, assessment of contaminant influx, and potential changes in upstream operation to make dam operation feasible.

Evaporation effects should be considered for the operation of a temporary lake during summer months. The approximate surface area of El Pueblo Lake would be about 20 acres $(4,500 \mathrm{ft}$ by $200 \mathrm{ft})$. On the basis of pan evaporation rates at the closest Los Angeles County evaporation stations (Rio Hondo (1014F) and Descanso Gardens (1071B) the evaporation for the period May through September may be 25 to 30 inches (Rodney Brown, Los Angeles County Dept. of Public Works, written commun., 2004), which implies a season evaporative loss of about 40-50 acre-ft from the proposed lake.
Possible limited removal of channel lining from the Arroyo Seco is being considered as part of the Confluence Park plan. An evaluation of the potential effects of lining removal along the Arroyo Seco has been done (Northeast Trees and Arroyo Seco Foundation, 2002). In the context of the proposed Confluence Park, issues to consider from a surface-water perspective related to channel-lining removal include flood response, flow travel time, ground-water recharge and discharge (and associated water-quality effects), and scour and erosion potential.

Construction of a temporary lake at the confluence will alter the flow of sediment through the channels. It is expected that particulate materials in the river discharge will settle behind the proposed structure, creating a deposit of sediment behind the dam. This sediment may influence water quality

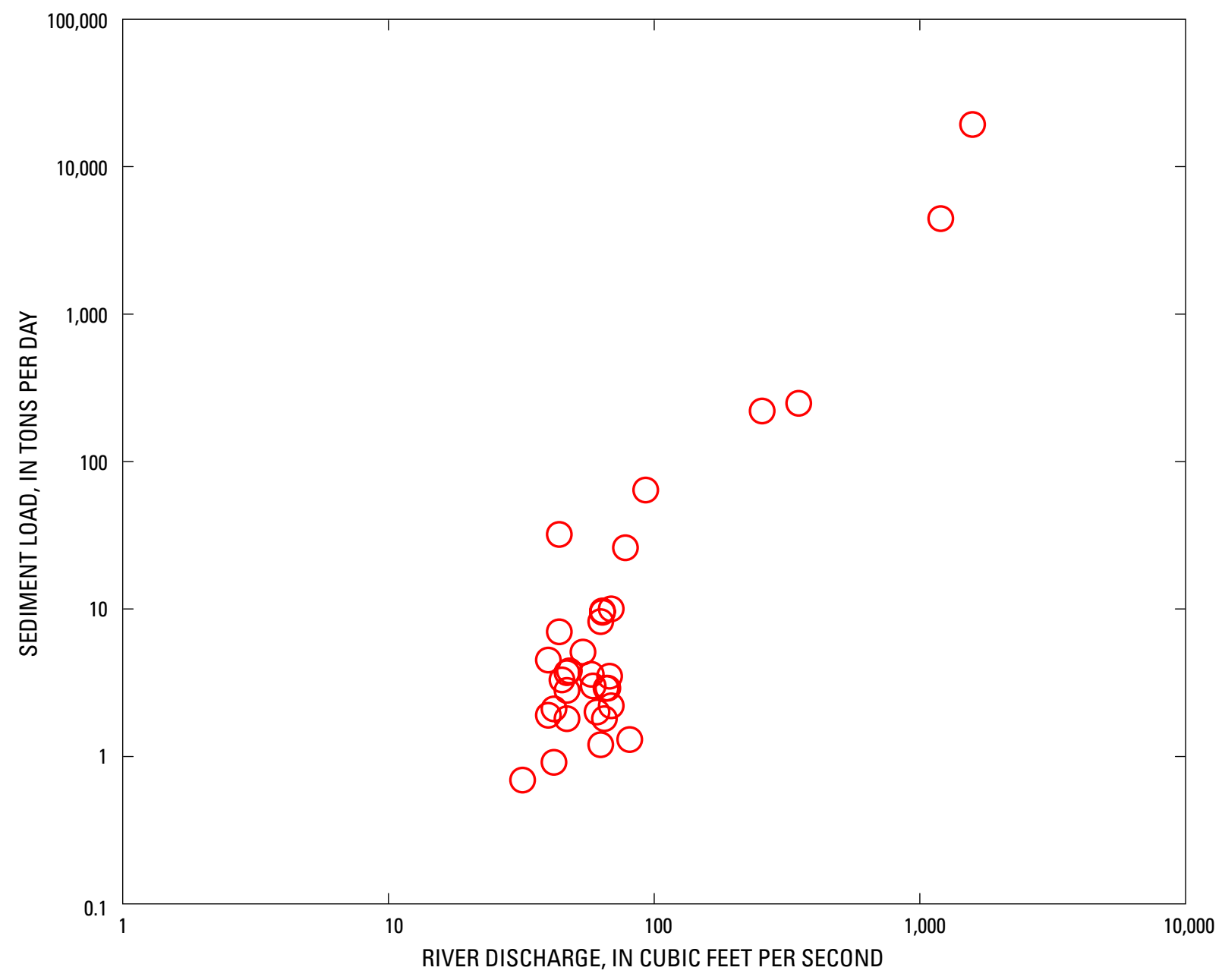

Figure 12. Relation between river discharge and daily sediment load for the Los Angeles River (USGS 11103000; see page 34) downstream from the study area. 
and may also provide for a "slug" of sediment that will be eroded and transported downstream following annual dam deflation.

Although most of the sediment transport in the Los Angeles River and Arroyo Seco occurs following winter rainfalls (when sediment is actively eroded from the landscape and river channel; Brownlie and Taylor, 1981; Inman and Jenkins, 1999), urban runoff and dry-season precipitation can introduce sediment to the rivers during the months of dam usage. For example, at the Los Angeles River at Long Beach (USGS 11103000, approximately $11 \mathrm{mi}$ downstream from the confluence), daily sediment flux during periods with flow less than $100 \mathrm{ft}^{3} / \mathrm{s}$ range from about .7 to 64 tons/day (fig. 12). Much of the sediment from these types of flows will deposit behind the proposed structure.

\section{Potential tasks}

1. Conduct an in-depth statistical analysis of historical surface-water discharge data. This will be important in the design and operation of the proposed El Pueblo Lake on the Los Angeles River (see, for example, the type of analysis shown in fig 11) and will provide guidance on likely effects of any channel-lining removal on the Arroyo Seco (Northeast Trees and Arroyo Seco Foundation, 2002).

2. Install or reactivate one or more gaging stations. One possible location would be on the Los Angeles River just downstream from the proposed lake. A second potential location would be at the lower end of the Arroyo Seco (to monitor impacts of channellining removal). In addition, seepage runs could be conducted along any newly unlined parts of the Arroyo Seco in order to quantify losses.

3. Reevaluate historical sediment data. Sediment data have been collected at a number of sites within the drainages of the proposed project, but the focus was on evaluating total sediment discharge, especially during winter storms (for example, Brownlie and Taylor, 1981; Inman and Jenkins, 1999). Since the period of interest is the dry season of the year, there is a need to reevaluate these historical data for the months of interest. Potential changes in watershed management also should be considered in this evaluation.

4. Conduct an expanded study of possible sedimentation that would occur within the proposed El Pueblo Lake, and what would happen to the sediment when the dam is deflated for winter flow each year. Develop a sediment-transport model, based on and calibrated to recent sediment data collected at cross sections above, in, and downstream from the lake zone (Bennett, 2001).

\section{Surface-water quality}

The overall water quality in the Los Angeles River generally is a function of quantity, timing, and source. To examine these factors and provide a preliminary description of temporal conditions, historical water-quality data collected at two gaging stations along the Los Angeles River (USGS 11097500, at Los Angeles and USGS 11097490 at Feliz Blvd.) were compiled. The period of record for these data is 1966-77, and thus does not represent current river conditions. However, the data do provide information on variability and patterns, and illustrate the value of reestablishing regular water-quality monitoring at gaging stations on the Los Angeles River and its tributaries. This is especially important because, as shown in figures 9-11, the dry-season flow regime has changed considerably over time, mostly owing to the increasing volumes of reclaimed water.

The range and distribution of selected physical parameters and chemical constituents are summarized in figure 13 , and the annual variation in dissolved oxygen and specific conductance, as well as the relation between dissolved oxygen and temperature, is shown in figure 14.

The boxplots in figure 13 show relatively constant $\mathrm{pH}$ values, dissolved-oxygen values that range considerably (mostly between 2 and $14 \mathrm{mg} / \mathrm{L}$ ), and temperature values that range from 4 to 25 degrees Celsius. Bicarbonate, chloride, and sulfate values show a moderate inner-quartile distribution; however, all three constituents have extreme values (outliers), suggesting different sources of water. Data also indicate that surface water in the Los Angeles River has a calcium/sodiumsulfate/bicarbonate composition. 


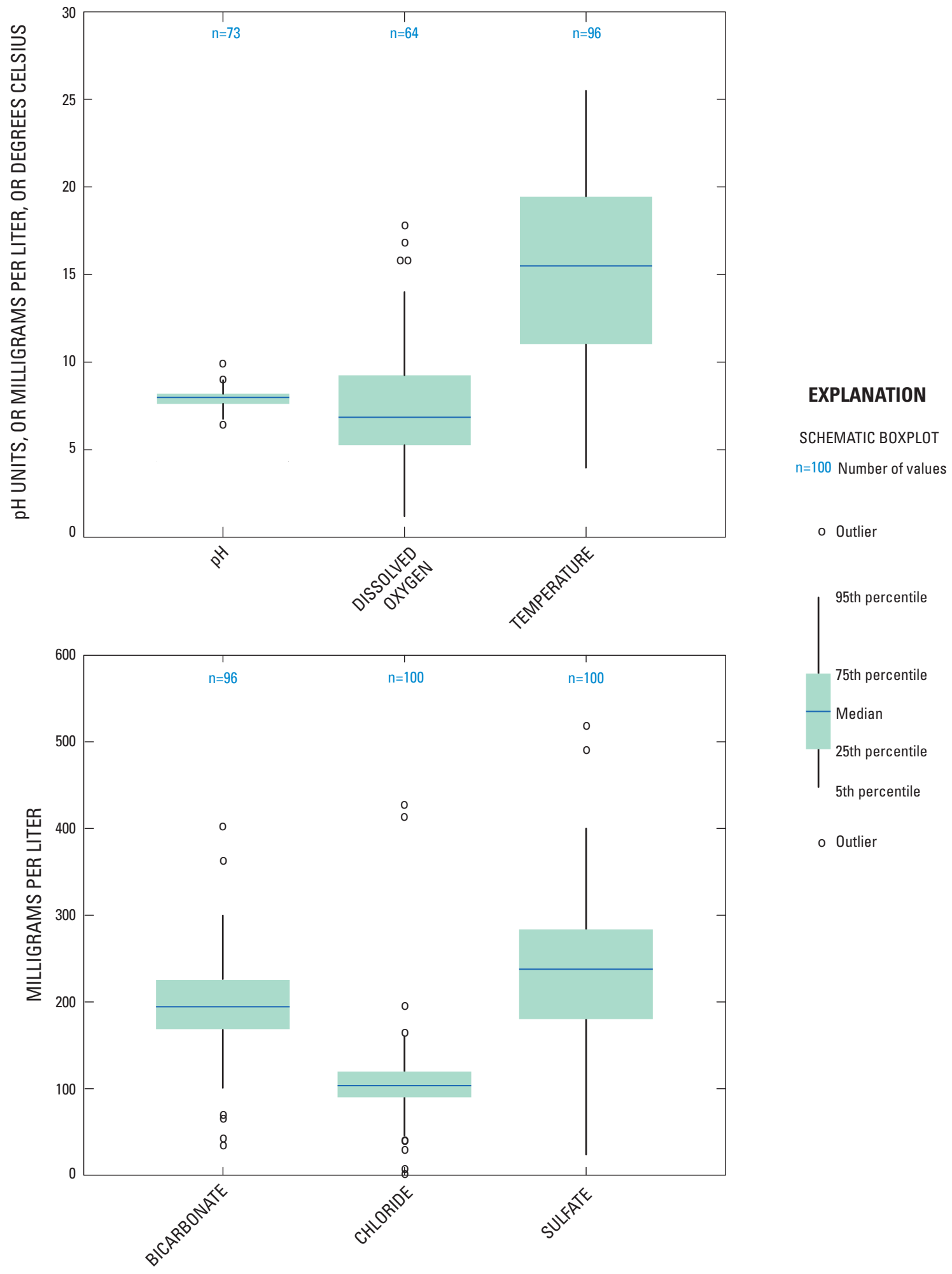

Figure 13. Concentration of selected constituents in surface water from the Los Angeles River, 1966-1977 (USGS stations 11097500 and 11097490). 
The graph in figure $14 \mathrm{~A}$ illustrates a smooth variation in temperature across the calendar year, with a maximum corresponding to the summer months when the proposed lake would be operational. In general, dissolved oxygen concentrations are inversely proportional to temperature, (fig. $14 B)$; dissolved oxygen concentrations in the river would also be lowest during the seasons when the proposed lake would be in operation. Closer inspection of figure $14 B$ indicates that a few high concentrations of dissolved oxygen (exceeding saturation) occurred during non-winter periods (temperatures greater than 20 degrees Celsius). This may be explained by the occurrence of local algal blooms that may supersaturate oxygen in the water.

Surface water containing the least amount of dissolved solids (as indicated by specific conductance values less than 600 microseimens per centimeter) occurs between the months of November and April (fig. 14C). In the adjacent coastal Santa Ana basin, lower values are associated with large-volume, winter stormflow events (Kent and Belitz, 2004). Higher values are more typical throughout the year (including winter periods without stormflow events). The effects of increased reclaimed water on this relation need to be addressed.

Given the degree of variability of major-ion concentrations in surface-water runoff in the Los Angeles River, a similar variation in the range and distribution of other water-quality indicators (for example, pesticides, volatile organic compounds, organic carbon, and nutrients) is expected to occur as well. The concentration and frequency of detection of some constituents will be directly correlated with flow, while others will be inversely correlated. For example, in the Santa Ana river basin, pesticides such as diazinon and simazine show a systematic decrease in detection frequency for two week period after a storm event. However, pesticides were detected more frequently and at higher concentrations during and 2-weeks after storms than during dry periods (Belitz and others (2004).

\section{Effects}

Surface-water quality will be of critical importance in the development of Confluence Park. The creation of a temporary lake allows for potential buildup of chemical contaminants. In addition, the proposed El Pueblo Lake would increase the likelihood of potential exposure (both human and animal) to contaminants. In a study conducted on the nearby Santa Ana River (Izbicki and others, 2000), samples were collected to measure changes in the concentration of selected constituents (nutrients, dissolved organic carbon components, selected pesticides and volatile organic compounds, and trace elements) under different flow conditions and upstream dam operations. The suitability of this water as a source of recharge (groundwater supply) to the basin also was evaluated.

The temporary lake also may influence the microbial characteristics of the reservoir water stored and discharged from this structure. Discharge from southern California streams and storm drain outfalls can be responsible for
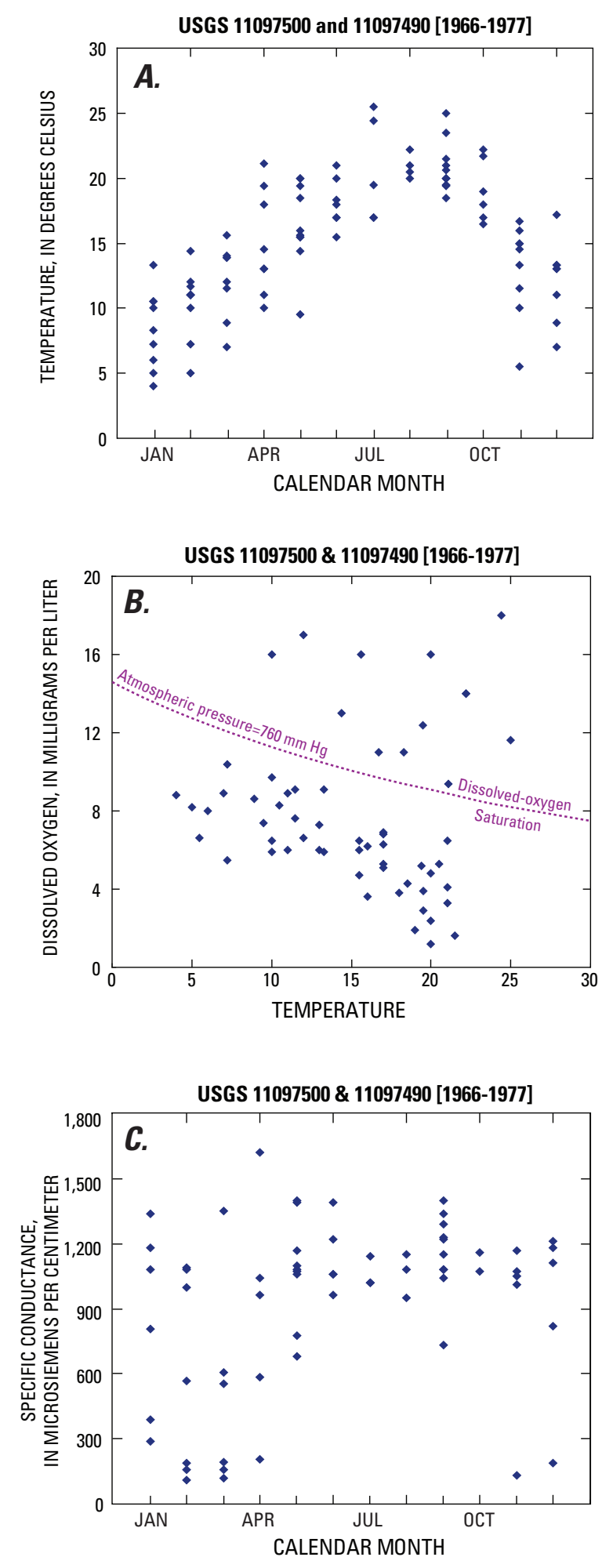

Figure 14. Annual variation in temperature $(A)$; relation between dissolved oxygen and temperature $(B)$; and annual variation in specific conductance (C) in water from the Los Angeles River, 1966-1977. 
degrading coastal water quality, especially owing to the introduction of coliform bacteria (for example, Bay and others, 1999). It is not known how operation of a dry-season lake will alter pathogen concentrations of the river water, although the structure may serve as a source of pathogens since wildlife and people will be attracted to it (for example, Grant and others, 2001). If the temporary lake becomes a significant source of pathogens, adequate cleanup methods for the water (for example, discharge into municipal wastewater treatment plants) will be needed.

\section{Potential tasks}

1. Collect additional data to better assess the suitability of surface-water sources for use in El Pueblo Lake during summer months, and for potential use as a source of ground-water recharge. For both planning and operational purposes, it is especially important to characterize the seasonal variations in the quality of inflow from the Los Angeles River and Arroyo Seco. Confluence Park presents an ideal location to establish a potential sampling site for a comprehensive waterquality assessment of drainage from the San Fernando Valley and Arroyo Seco watersheds. Monitoring should include parameters currently being monitored at other active sites; more detailed evaluation of the dissolved organic carbon, volatile organic compounds, pesticides, trace elements, selected isotopes, and emerging contaminants (for example, perchlorate, antibiotics, endocrine disrupters) also may be appropriate. The USGS has established methods for the collection and analysis of these types of samples.

2. In addition to targeted point sampling, continuous monitoring of parameters such as specific conductance, temperature, dissolved oxygen, turbidity, chlorophyll, nutrients, and $\mathrm{pH}$ (using a multi-probe sonde) should be considered. Monitoring the daily fluctuation of these parameters would be particularly relevant for understanding the potential for algal blooms in the proposed El Pueblo Lake.

3. Conduct a detailed assessment of the water-quality changes that could result from the likely increase in discharge of recycled water from the upstream Donald C. Tillman, Burbank, and Los Angeles-Glendale water-reclamation plants (Schroeder, 2003; Anders and Schroeder, 2003; Anders and others, 2004).

4. Design and implement microbial monitoring plans for source and lake waters. The complex dynamics of microbes in urban water bodies make prediction of the influence of the proposed project difficult. Thus, pathogen monitoring of the source and proposed lake waters is needed. The monitoring data would be incorporated into a water management plan that addresses the potential for waters impacting river and coastal zones (Grant and others, 2001; Izbicki, U.S. Geological Survey, written commun., 2004)

\section{Ground-water hydraulics}

\section{Effects}

Ground-water levels would probably not be significantly affected by the development of a park at the confluence. Los Angeles County well 2781 (fig. 8; State of California well number 001S014W14E003S) is an active observation well near the Arroyo Seco with recorded measurements dating back to the 1930s. As shown in figure 15, the water level in this well is shallow-about $40 \mathrm{ft}$ below land surface-and has not fluctuated substantially over the period of record. This is consistent with most water-levels in the surrounding Glendale Narrows and is mostly a function of the relatively thin alluvial deposits (see "Geology" section), ground-water flow from the adjacent San Fernando Valley, proximity to the unlined portion of the Los Angeles River, and the lack of significant pumping in the nearby area.

Channel-lining removal along a small section of the Arroyo Seco is not expected to have a significant effect on ground-water levels, since there is little storage capacity to accommodate additional recharge. However, small amounts of recharge, depending on the source, could affect ground-water quality (see "Ground-Water Quality section"). Collection and evaluation of specific hydrologic (water-level, water-quality, and temperature-log) data and stratigraphic information would be required to make this determination.

To measurably affect ground-water recharge, a significant portion of the channel lining would have to be removed. The area downstream from the confluence-the Los Angeles Forebay in the Central Basin (see fig. 8) - is better suited as a potential location for augmentation of ground-water recharge. In the Los Angeles Forebay, water levels have declined considerably over a large area as a result of intensive pumping (Water Replenishment District of Southern California, 2004a; Reichard and others, 2003).

\section{Potential tasks}

1. Collect and compile water-level, water-quality, and temperature-log measurements at selected existing wells to provide a preliminary baseline for evaluating potential changes in the ground-water flow system that could result from the development of the confluence area.

2. Install new multiple-well monitoring site(s) to facilitate the collection of basic hydrologic and detailed lithostratigraphic data with good depth control. Although several wells already are present in the study area, most are shallow (less than $50 \mathrm{ft}$ ), and do not, by themselves, provide the means to adequately describe the three-dimensional groundwater flow system. The multiple-well monitoring site(s) will provide new detailed data on lithology, physical properties, 


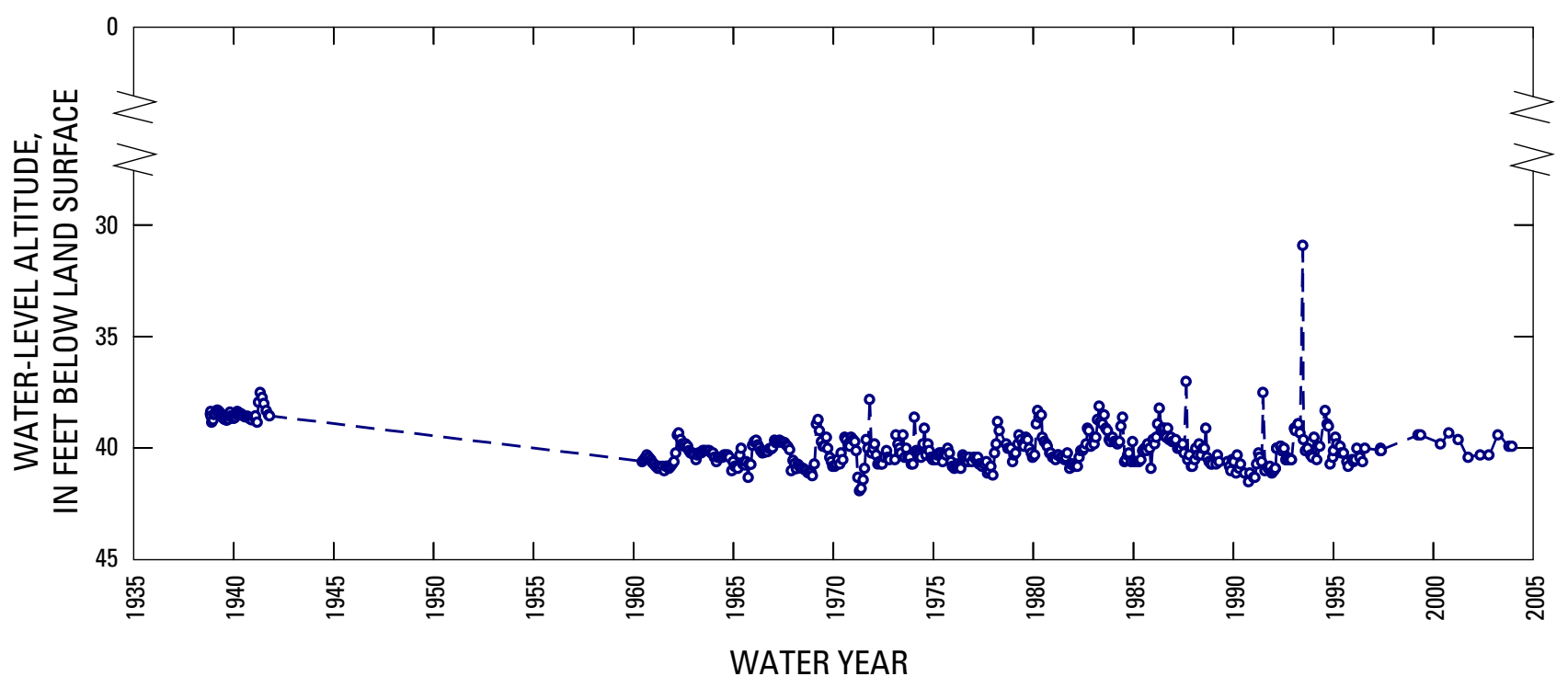

Figure 15. Water-level hydrograph for well 2781 (State of California well number 001S014W14E003S) in the study area.

water levels and water quality. Several such sites have already been constructed in the adjacent Central Basin (Land and others, 2002); most have been outfitted with a data logger to record water-level changes in each aquifer zone (Water Replenishment District of Southern California, 2004b).

3. Reevaluate the hydrogeology of the confluence area. Utilize newly collected subsurface data (gathered from the task above) and sequence stratigraphic methods to correlate the unconsolidated deposits and develop a sequence-based framework for quantifying ground-water/surface-water interactions and identifying potential contaminant pathways (Hillhouse and others, 2002).

4. Develop a ground-water flow model to quantitatively assess the ground-water effects of alternative scenarios for lake design and channel-lining removal. A promising groundwater modeling approach would be to incorporate the updated MODFLOW (Harbaugh and others, 2000) packages to more rigorously consider stream-routing contaminant transport and ground-water-lake interaction (Merritt and Konikow, 2000; Prudic and others, 2004). Such modeling should consider different scenarios: presence/absence of a dam; extent of channel lining; and different inflows from both the Los Angeles River and the Arroyo Seco. Recent modeling applications of this type for a regional cross section typical of non-humid portions of the western United States have been completed by Constantz and Essaid (2003). On a larger scale, there would be benefits for developing a regional model that incorporated the upper basins (San Fernando and Arroyo Seco watersheds), the Glendale Narrows, and the lower coastal plain basins (Central, Hollywood). An important use of this unified model would be to better quantify the ground-water flux through the Glendale Narrows.

\section{Ground-water quality}

\section{Effects}

Creation of the proposed El Pueblo Lake as currently envisioned (City of Los Angeles, 2004) will likely have little effect on ground-water quality. However, any channel-lining removal within the Arroyo Seco may affect ground-water recharge, and, hence, ground-water quality. In addition, if development of Confluence Park is coupled with the implementation of new artificial recharge facilities in adjacent areas (see "Potential tasks" below), ground-water quality may be affected.

In either case, a network of monitoring wells and a sampling program would need to be established to assess the effect and magnitude of these changes.

Contaminants in shallow ground water in the Glendale Narrows may affect the Confluence Park development by degrading the quality of water to the proposed El Pueblo Lake (Santa Monica Mountains Conservancy, 2003; Environmental Resources Management, 2000). The presence and continued input of these contaminants may adversely affect the ecosystem health (see "Ecotoxicology" section). For example, a survey of organic compounds and heavy metals 
in streambed sediment, reservoir sediment, and fish tissue collected at sites along the Santa Ana River by Burton (2002) showed more frequent detections at urban sites than nonurban sites. In addition, these data provide a historical record of accumulation of pesticide, organochlorine and semivolatile organic compounds.

\section{Potential tasks}

1. Assess the occurrence and distribution of contaminants in the ground-water system through compilation of existing data and sampling of new and existing wells in the Glendale Narrows. Besides characterizing the vertical distribution of contaminants, the collection of chemical data could address additional questions:

a. What is the source(s) of ground-water recharge (local rainfall, urban runoff, stormwater, wastewater, underflow from an adjacent basin)?

b. Are distinct ground-water flow paths discernable? If so, what is the susceptibility of ground water in deeper aquifer zones of the Glendale Narrows area to contamination?

c. Are decreases in contaminant concentrations driven by natural bioremediation processes or by dilution?

2. Install a multiple-well monitoring site(s) (see "Ground-Water Hydraulics" section) to facilitate the collection of water-quality data from depth-specific aquifer zones. This would also provide information on ground-water conditions in the deepest unconsolidated deposits and underlying consolidated deposits for which little information currently is available. The total borehole depth, depending on location (fig. 4), would be as much as $300 \mathrm{ft}$.

3. Conduct a one-time collection of streambed-sediment cores in the unlined portion of the Los Angeles River for selected constituents of concern. Sediment accumulated in the channel at the end of the dry season also should be sampled and analyzed. The occurrence of these constituents in fish (or other animal) tissue also should be measured and included as part of any ecosystem health assessment (see Burton, 2002).

4. Evaluate strategies for operating the proposed El Pueblo Lake in conjunction with potential future projects for improving water-quality and enhancing ground-water recharge downstream, such as:

(1) diverting water into spreading ponds adjacent to the site or to injection wells in the Central Basin, (2) unlining and widening portions of the Los Angeles river channel. 


\section{Biology}

\section{Biologic overview of the study area}

\section{Biological setting}

Southern California is home to a rich diversity of native and introduced biota. In this arid region, riparian systems, such as the Los Angeles River and Arroyo Seco, provide narrow bands of habitat within which a disproportionate diversity of species reside for part or all of their life cycle. In coastal southern California, flood control and urbanization have massively altered most native riparian ecosystems, even confining them within concrete-lined channels. The result has been the reduced distribution and abundance of many species native to southern California. For many native species, habitat alteration has resulted in their inclusion on lists of imperiled species. The Least Bell's Vireo, Southwestern Willow Flycatcher, Arroyo Toad, Santa Ana Sucker, and Unarmored Threespine Stickleback are some of the federally listed species native to the streams and riparian corridors of southern California.

Developments as part of the proposed Confluence Park could affect the habitat suitability for native species in this region. Although the Los Angeles River's highly altered nature and urban setting make restoring anything similar to the original system especially challenging, even small enhancements would represent a relatively large improvement over current conditions. In the area proposed for Confluence Park, upland habitats are now completely paved, and the Arroyo Seco and Los Angeles River are confined within concrete-lined channels. Any naturalization of this area would increase habitat suitability for plant and animal species. Ecological restoration projects such as that being considered for Confluence Park are reclaiming habitats in cities around the world. In many cases, these projects additionally provide opportunities to (1) learn how to achieve restoration goals and (2) test theoretical models of ecological functioning in the process.

\section{Biological monitoring and modeling}

The collection of scientific monitoring data is essential to rigorously document the changing status of environmental resources. The USGS is involved in a number of biological research and monitoring projects in the Los Angeles region. The project closest to the confluence area is at Debs Park, which is situated less than $2 \mathrm{mi}$ upstream along the Arroyo Seco (fig. 16). At this and other sites in the region, USGS biologists and cooperators are monitoring populations of reptiles and amphibians to better understand their interactions with human-dominated landscapes. Farther upstream in tributary creeks of the Angeles and San Bernardino National
Forests, USGS biologists are studying endangered amphibians and fishes to determine the causes of endangerment and to assist with planning for their recovery.

The locations of nearby USGS biological research sites during the past five years are shown in figure 16. This map also includes a simplified view of regional land cover, to illustrate the extreme degree to which this region has been urbanized. On this map, the pink shaded areas represents developed land uses identified as residential, commercial, industrial, or transportation; scrub, forested upland, shrubland, grassland, or recreational land use dominate the green shaded areas.

As efforts to restore habitats within urban areas spread, monitoring is needed to track progress, guide ongoing actions, and identify programs that are not working. Until recently, conservation and restoration projects were evaluated primarily on aesthetics and the assumption that doing something was better than doing nothing. This approach is changing; increasingly, practitioners must document the results of their work (Christiansen, 2003, 2004). Although a biological monitoring program adds some cost to restoration, it also establishes credibility and allows objective assessment of what works, and what does not, and suggests opportunities for improvement (Block and others, 2001). Whereas monitoring facilitates after-the-fact evaluation of resource status and program progress, ecological modeling in advance to project implementation helps create plans that are more likely to succeed.

An example of ecological modeling in support of conservation planning is recent work on mountain lions and bobcats in southern California (Hunter and others, 2003). That project used habitat models to identify remaining regions of suitable habitat, based on habitat preference studies and region-wide GIS habitat maps. It identified missing or threatened habitat linkages and provided land managers with a tool allowing them to focus habitat acquisition and management efforts in the most critical areas. In another project, biologists evaluated the potential impacts on the endangered arroyo toad of a range for dam management options. For this risk assessment, the model was a representation of the species life history. Comparing the life history model with management options revealed that managers should avoid dam releases when the greatest number of egg masses and tadpoles are most likely to be present (Madden-Smith and others, 2004). Moving beyond trial and error towards true adaptive management requires the adoption of an ecological modeling perspective during the formulation of plans. Collection of monitoring data before and after project implementation allows managers to evaluate if the system responded to treatments in the ways suggested by the model, and, where necessary, to refine the model. 

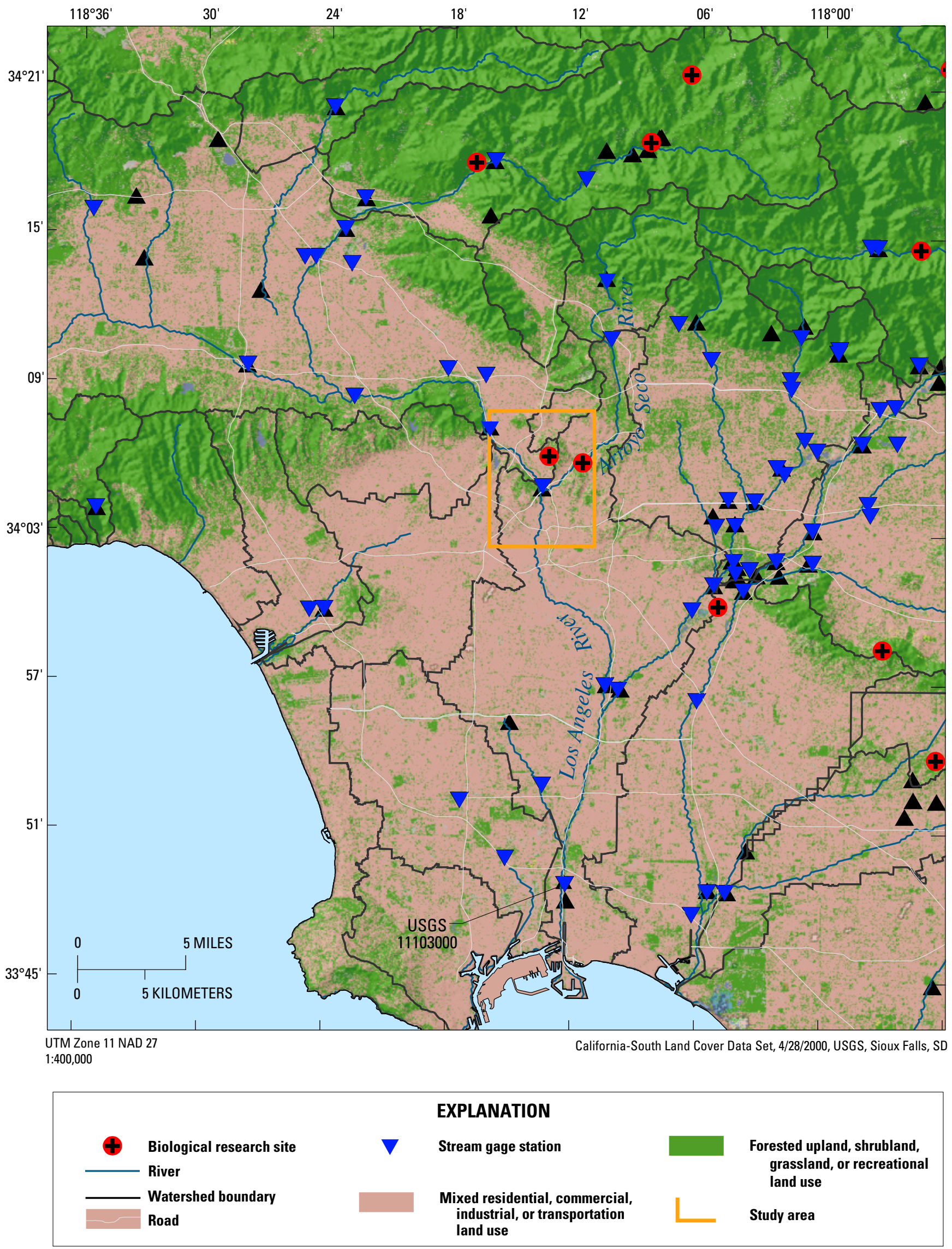

Figure 16. Watershed boundaries, selected stream gages, and U.S. Geological Survey biological research monitoring sites. 


\section{Biological Issues}

\section{Wildlife Corridors}

\section{Effects}

Large areas of southern California have become urbanized, creating isolated or weakly connected patches of native habitat (for example, urban parks, urban canyons). Over time, as chance events lead to local extinctions, biological diversity in isolated habitat patches declines, and without functional corridors there is little hope for natural reestablishment of new populations. Restoring habitat corridors through urban areas can improve this situation by increasing connectivity among remaining and restored habitat patches. In southern California, biologists have already attempted to identify corridors that facilitate dispersal among habitat patches, and locations where compromised connections may be restorable. Most related studies have focused on medium to large mammals such as bobcats and mountain lions (Hunter and others, 2003). Bolger and others (2001) also assessed the use of coastal sage scrub habitat strips by birds and small mammals. In fragmented landscapes, habitat corridors are of key importance for maintaining widespread wildlife populations, especially for species such as large and small mammals, reptiles, and amphibians. Riparian areas, in addition to linking natural hydrological systems, commonly provide the best opportunities for wildlife movement through urbanized areas.

Although the Los Angeles River and the Arroyo Seco are highly altered systems, they nevertheless serve as corridors for dispersal, as shown by recent reports of mountain lions in Griffith Park. Animals such as foxes and coyotes also may move deliberately through these corridors; winter floods may be responsible for the involuntary downstream dispersal of some plants and animals. If individuals reach suitable habitat, they may survive and establish populations. Restoration of upland habitats in conjunction with the creation of Confluence Park could increase the area of suitable upland habitats in the vicinity. In addition, if animals disperse in a "stepping-stone" fashion, creation of even small patches of naturalized habitat may enhance dispersal disproportionately. The creation of the proposed El Pueblo Lake along the Los Angeles River, however, could seasonally eliminate or dramatically reduce habitat connectivity for upland and aquatic species that move through the river channel (for example, coyotes and fishes).

\section{Potential tasks}

1. Monitor existing and future restored upland areas for colonization by wildlife, especially non-flying species. Natural recolonization of upland areas will provide information regarding which animals are using the river channels as movement corridors. To detect the wide range of species potentially utilizing these habitat areas, a variety of survey methods would need to be applied.

2. Develop a Geographic Information System (GIS) based model of potential changes in habitat connectivity along the Los Angeles River and the Arroyo Seco caused by proposed park development. Methods exist for modeling regional habitat connectivity on the basis of species habitat requirements (see Hunter and others, 2003). Models should address effects on a range of species that have differing habitat requirements (for example, coyotes, western toads, steelhead, arroyo chubs).

3. Conduct long-term monitoring of wildlife traffic through the Los Angeles River and the Arroyo Seco channels before and after creation of the Confluence Park. Monitoring should be designed to test specific hypotheses about the value proposed design elements have in facilitating or blocking wildlife movement. Obtaining baseline data before habitat is altered is essential for demonstrating the relationship between design elements and habitat use by wildlife.

\section{Wildlife Colonization/Reintroduction}

\section{Effects}

As habitats in urban areas are restored to more natural states, some species will immigrate and establish populations. However, other species of interest may not be able to colonize naturally (Trenham and Marsh, 2002). For those species, if project goals include the establishment of these species, intentional reintroduction may be necessary. For example, the Black-bellied slender salamander is a species that is abundant throughout residential Los Angeles, but because it is a poor disperser it is unlikely to colonize the restored upland habitats of Confluence Park. The western fence lizard and various flightless invertebrates (for example, scorpions, Jerusalem crickets, darkling beetles) also are common regionally, but have limited dispersal capacities. Table 1 lists the dominant native plants found along the Los Angeles River corridor, and table 2 lists vertebrate and invertebrate species that occur in natural areas near the project site and the types of habitat they usually occupy.

There is great potential for use of the proposed park site as a laboratory for wildlife reintroduction in an urban setting. Relocations of wildlife are common, but projects that attempt to develop standard procedures for reintroduction, and which critically evaluate the success of these efforts, are rare. Some important questions that wildlife reintroductions should address include (Block and others, 2001; Semlitsch, 2002)

- How many individuals of what life-history stage will be released? 
- Where is an appropriate source population?

- Will relocated individuals attempt to return home or will they settle in the restored area?

- How will project success be measured?

A decision to attempt an introduction should reflect a match between (1) the species habitat needs and (2) the extent of habitat present. Habitat area is at least as important as the type and condition of the habitat available. A novel use of reintroduction would be as a measure of restoration success, with a monitoring program instituted to verify population establishment and growth. Although the translocation of organisms holds great potential promise as a method for restoring ecological systems, caution is warranted to avoid detrimental impacts to desirable organisms already occupying the release site. Potential risks include introduction of disease, parasites, and maladaptive genotypes. It is critical that organisms only be translocated to sites without extant conspecific populations (if a population exists already, habitat improvements should be sufficient to increase numbers). Because many species differ genetically from location to location, at a minimum the source of organisms should be as close to the release site as possible. However, ideally, a genetic study would be conducted to identify the best potential source population.

\section{Potential tasks}

1. Inventory and monitor plants and small animals for 2 to 4 years following habitat restoration. Determine species that colonize restored habitat areas, and how their densities change over time.

2. Use wildlife-habitat relationship models to determine species that potentially could be supported on-site. If priority species cannot be supported by the site as currently configured, then revision of restoration design may be needed to remedy this situation.

3. Introduce and monitor populations of desirable species that inventories have shown to be absent from the site. Species should be selected on the basis of an assessment of the available habitats, space, and other requirements (Task 2). Ideally introductions should be conducted as experiments to learn how to better conduct future introductions, and to test theories and assumptions regarding the species biology, or both.

4. Consider using topsoil relocation as a strategy for establishing a diverse community of native plants. Topsoil can be obtained from nearby sites slated for development. This method has been shown to be more successful than seeding in other systems. If there is evidence or concerns that existing on-site soils are contaminated, this would also be a potential remedy.
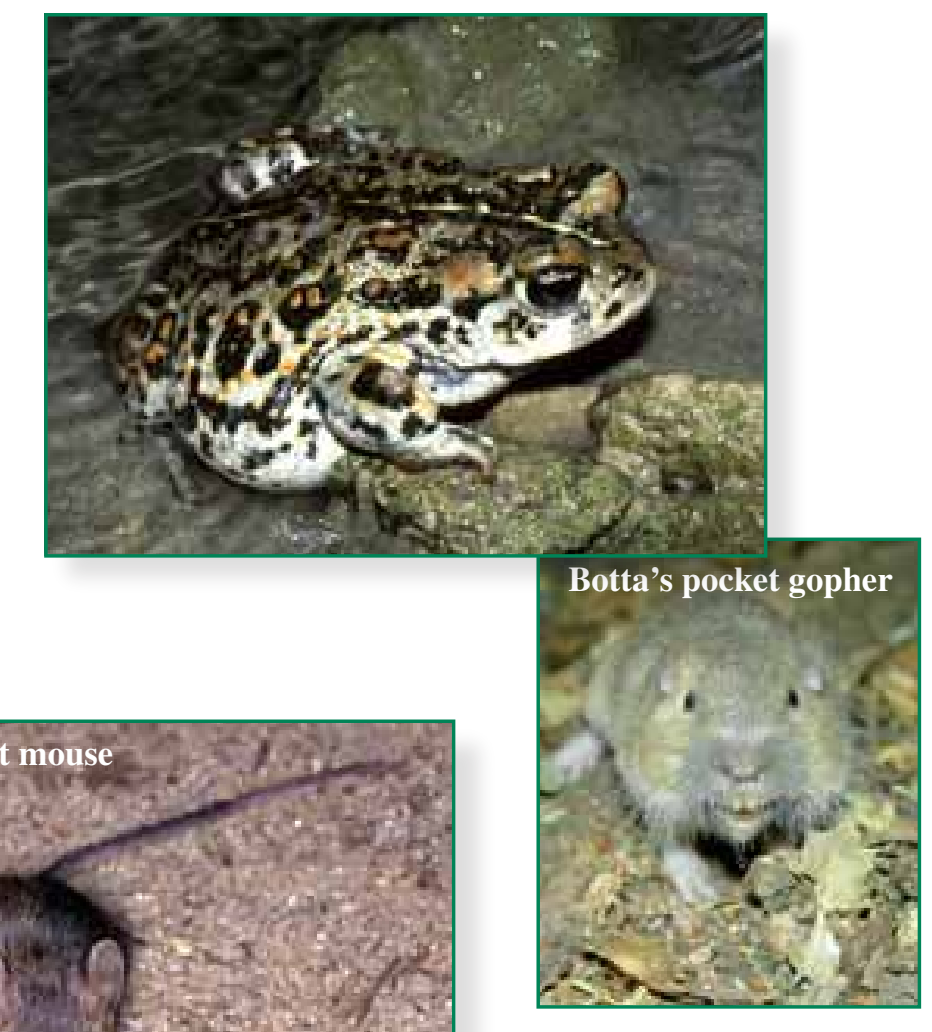
Table 1. Native vascular plants documented at sites along the Los Angeles River.

$[\mathrm{N}=$ number of sites out of 14 visited where that species was observed (Wallace, 1993). General habitat types where species were found: in standing or moving water; wet sandy areas away from channel; deeper soils but at edge of water; deeper moist soils permanent gravel bars; dry, at least on surface, gravel alluvium; and dry elevated gravel banks and concrete banks]

\section{Scientific Name}

\section{Habitats Where Each Species Was Observed}

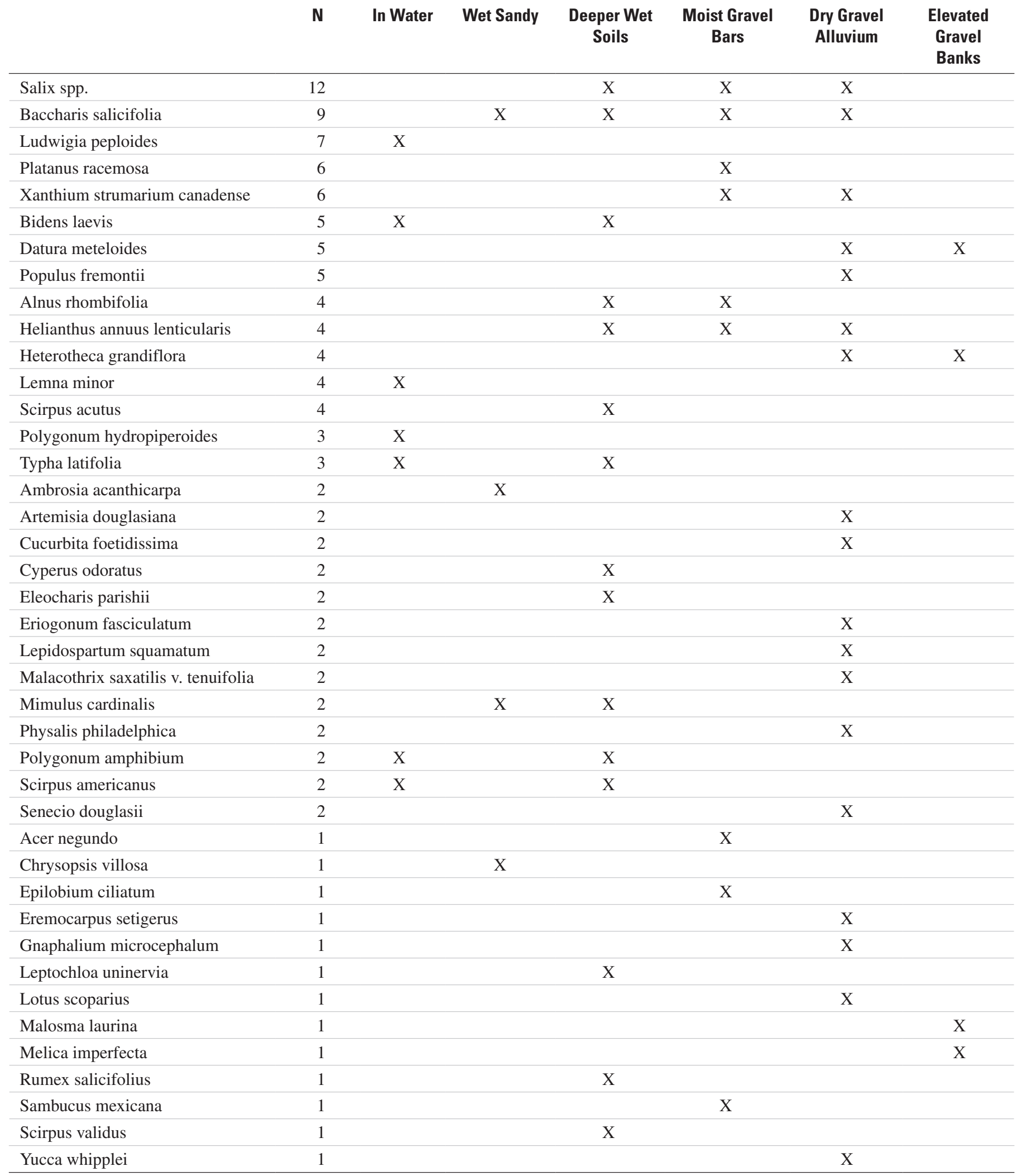


Table 2. Native species with potential to establish resident populations within the proposed Confluence Park.

[Asterisks denotes species captured by USGS at Ernest E. Debs Regional Park which is less than 2 miles upstream and adjacent to Arroyo Seco; pound sign denotes species reported by others at Debs Park.]

\begin{tabular}{ll}
\hline \multicolumn{1}{c}{ Common Name } & \multicolumn{1}{c}{ Basic Habitat Associations } \\
\hline * Western skink & Scrub/Grassland/Forest \\
* Western fence lizard & Generalist/Perches \\
California legless lizard & Sand/Loose Soil/Litter \\
* Western whiptail & Dense Scrub/Loose Soil \\
Side-blotched lizard & Open/Rock/Sand \\
\# Southern alligator lizard & Generalist/Open Canopy \\
* Ringneck snake & Forest/Scrub \\
\hline \# Pacific slender salamander & Forest/Scrub \\
Pacific chorus frog & Breeds in Slow Moving Water /Generalist \\
\# Western toad & Breeds in Slow Moving Water /Generalist \\
$*$ Harvest mouse & Dense Grass/Scrub \\
* Botta's pocket gopher & Open Grass/Scrub/Forest \\
\hline Arroyo chub & Sand or Mud Bottom/Slow Water \\
\hline Jerusalem cricket & Loose Soil \\
Darkling beetle & Generalist \\
Scorpion & Surface Cover Items/Generalist \\
\hline
\end{tabular}

\section{Non-Native and Pest Species}

\section{Effects}

Prominent among the threats to California's native biodiversity is the introduction of species from outside of the region. Non-native species often establish thriving populations that compete with natives for resources or prey on them directly. Abundant non-native species pose a challenge for restoring native communities, a challenge which is even greater in urban areas (Weiss, 1999). Non-native plants often invade disturbed habitats and can alter system conditions to the point where the habitats are unsuitable for native plants and animals (for example, vast ice plant and giant reed monocultures). In urban aquatic systems, the persistent release of pet animals (for example, turtles and fish) makes eliminating those species virtually impossible (Spinks and others, 2003). Fortunately, the distribution and abundance of most non-native species can be controlled with regular "weeding" programs, typically educating local volunteer workers in the process. Providing educational materials and outreach through pet stores, nurseries, and schools may also reduce future releases.

In addition to concern for native species, habitat restoration projects must also consider public health and safety. Probably the largest public health concern relative to this project will be worries that mosquito populations, and thus increased disease transmission, may be enhanced. During calendar year 2004, Los Angeles county had 328 confirmed cases of West Nile Virus with 13 related deaths (State of California, 2005). Presently the channelized portions of the Los Angeles River and Arroyo Seco contain relatively few areas of standing water where mosquitoes breed, and restoration efforts should avoid creating new breeding sites. Rats are the other major pest that any project design should seek to discourage.

\section{Potential tasks}

1. Inventory and monitor study area to determine the presence and population densities of invasive species of plants and animals.

2. Conduct studies to determine the level of effort and frequency of weeding/trapping/poisoning programs needed to restrict populations of non-native and pest species at an acceptable density (Keitt and others, 2002).

3. Create educational materials to inform visitors of local biological issues. Signage explaining how the release of domestic animals can massively disrupt natural systems, could help minimize future introductions. Presenting visitors with a clear vision of the desired 
future condition of the local system could also help them understand why certain restrictions exist and win over advocates.

4. Determine the best management policies for operation of the proposed El Pueblo Lake to minimize mosquito problems.

\section{Ecotoxicology}

\section{Effects}

Past land-use effects and on-going contamination present additional challenges for habitat restoration in urban areas. It should be recognized that chemical contamination will likely limit the pool of species capable of surviving in the restored habitats. Failure of plant or wildlife populations to thrive within the project area may be due to contamination rather than the absence of suitable habitat. Water present in aquatic habitats in urban settings commonly originates from storm runoff, discharge from wastewater treatment facilities, and urban runoff (surface water quality is discussed in detail in the "Hydrologic Issues" section). Areas currently paved may have contaminated soils, and substances from nearby contamination could potentially migrate onsite over time. Finally, nonpoint sources such as automobiles can contribute persistent detrimental chemical inputs such as heavy metals, organics, and nitrogen (Weiss, 1999).

\section{Potential tasks}

1. Before, during, and after redevelopment construction, conduct regular sampling of aquatic benthic invertebrates in the study area.

2. Conduct bioassays or analytical analyses of upland soil toxicity. Rearing small animals such as salamanders or earthworms in soils from the site may lend insights into the capacity of the site to support certain species.

3. Consider the inclusion of off-channel pools that fill with rainwater and local runoff, as part of the habitat restoration. These pools would be less subject to runoff-borne contamination and thus might provide important aquatic habitat for wildlife.

\section{Options for Restoration of Local Habitat and Ecology}

The various design elements that are either currently being considered, or that could be considered in the future, will affect the local habitat and ecology in different ways. Recognizing that not all suggested restoration elements might be implemented or even feasible, they are considered independently.

\section{Effects}

Temporary lake- Birds, bats, and flying insects are attracted to inundated areas as sources of food and water. Insects and some amphibians could possibly use a temporary lake as breeding habitat; however, because the lake will not be permanent, breeding populations of fully aquatic species will not become established. As mentioned previously, the movement of some animals (for example, coyotes and fishes) along the Los Angeles River corridor would be reduced or eliminated during the months when the lake is full, reducing the potential for colonization of nearby upland habitats. The impediment to movement of terrestrial organisms might be reduced by providing as wide an undeveloped upland buffer as possible along one side of the lake. Two additional effects to consider are the potential establishment of non-native/pest species and poor water-quality conditions. Because most non-native aquatic pests (for example, bullfrogs, largemouth bass, red-eared slider turtles) require a permanent source of water, their establishment is unlikely. Additionally, as a result of non-point source contributions and upstream contamination, water quality in the temporary lake may not be suitable for human use and wildlife. Finally, with emerging diseases like West Nile Virus, alterations that might enhance mosquito populations may meet opposition.

Removal of concrete from channel bottoms - Unlined portions of the Los Angeles River, just upstream from the confluence (fig. 2), support riparian vegetation. Channellining removal on parts of the Arroyo Seco could help to create a more natural streambed. This would replace the current homogeneous flat concrete bottom with a mildly meandering low-flow stream course, possibly including a heterogeneous mix of runs and pools. The first result would be the reestablishment of riparian vegetation in the stream channel. A variety of wildlife species are also likely to benefit. Birds may feed, roost, and nest in new riparian vegetation. Butterflies and other terrestrial invertebrates would benefit from increased riparian vegetation. Areas of open water would likely attract wading birds and waterfowl. Amphibians may breed in off-channel pools, and there is even potential for the creation of aquatic habitat suitable for the native Arroyo Chub. The increased vegetative cover and a more natural habitat structure would also enhance the value of these channels as wildlife corridors.

Concerns that would have to be addressed if lining removal is implemented include the proliferation of invasive species. Because giant reed (Arundo donnax) is likely to colonize the restored creek channel, a weed management plan would be an essential project component. Pools in the creek may become infested with crayfish, mosquito fish, and other exotics; these also could be reduced by persistent removal with minimal effort. In addition, attracting wildlife may be detrimental to individual health and the maintenance of resident populations if water quality is poor. 
Replacement of vertical channel walls - At the confluence, flow in the Los Angeles River and the Arroyo Seco is contained by concrete channels walls that, in some areas, are vertical and more than 10 feet high. For most nonflying vertebrates, such as mice, toads, and certain insects, these walls likely prevent movement between the riparian corridor and upland habitats. One possible expansion of currently considered plans for the Confluence Park could be to replace the vertical walls with more mildly sloped concrete banks on the Arroyo Seco (Northeast Trees and Arroyo Seco Foundation, 2002). Further consideration of this option would require engineering analysis to determine feasibility. Sloping walls would allow a greater diversity of non-flying vertebrates to move back and forth across the channels and between upland habitats. A design that allows vegetation to establish along the banks would provide cover and food for animals and a more natural transition between the stream and upland habitats. Riprap construction might also provide habitat or temporary refuge for small animals. Wildlife species benefiting from this design would include invertebrates, reptiles, amphibians, and small mammals; of potential concern is that the habitat for rats may also be enhanced.

Establishment of native upland vegetation/gardensCurrently this area supports essentially no plant or animal life, so any revegetation would be an improvement. For the revitalization of upland habitats, the planning documents suggest a variety of alternatives including some reestablishment of native vegetation. Any attempt at revegetation would begin with the removal of pavement. Then the rehabilitation or removal of the underlying soil may be necessary if contamination has occurred. Native plants and topsoil may be obtainable from nearby sites scheduled for development. Introducing plants along with their native topsoil may speed the establishment of other species commonly missing from restoration project sites, such as annual plants, soil insects, worms, microbes, and fungi. Native plants recorded in surveys of 14 sites along the Los Angeles River (Wallace, 1993) are summarized in table 1.

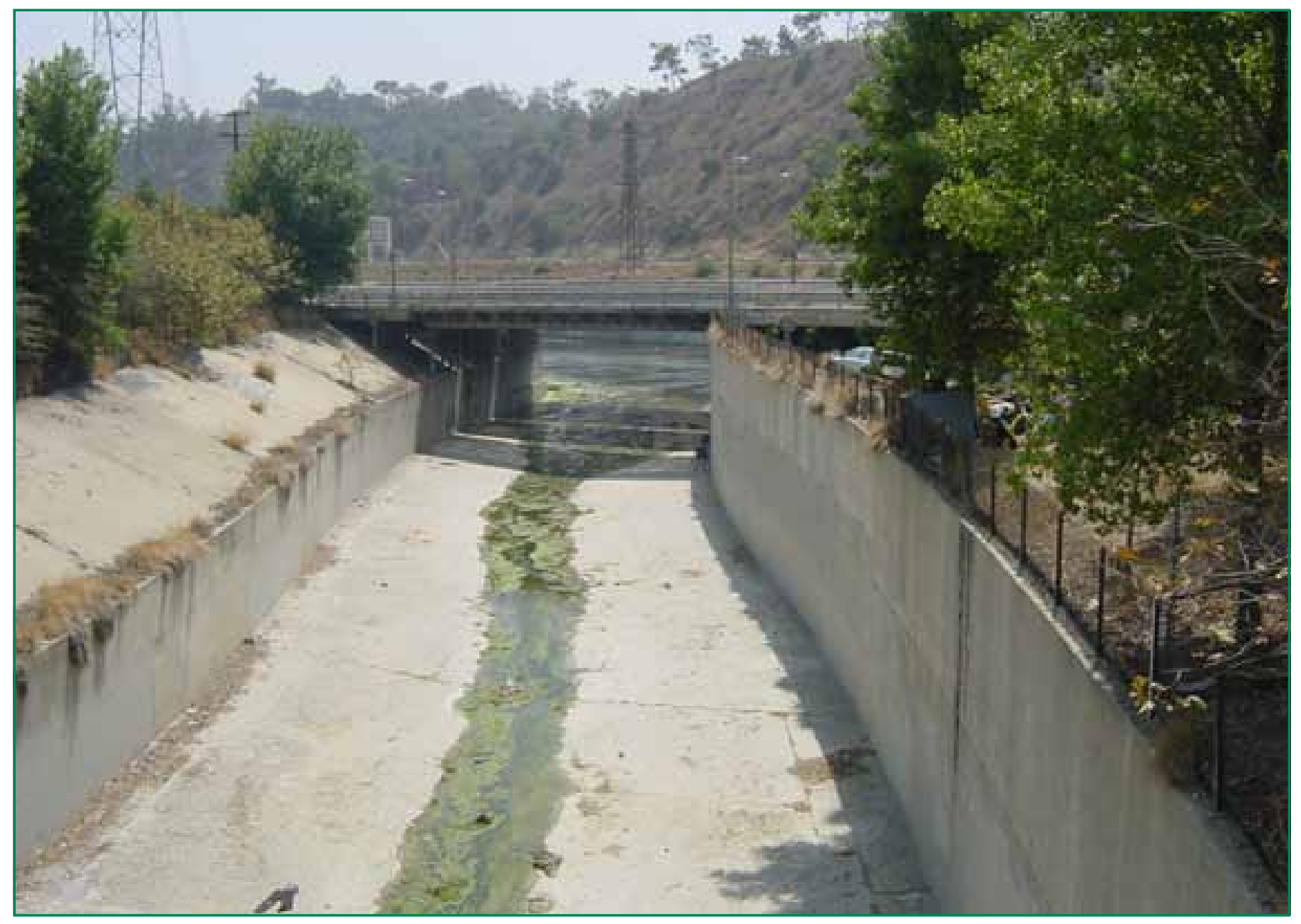

View of the Arroyo Seco entering the Los Angeles River (photograph by Dale Cox, U.S. Geological Survey) 
Although native gardens would likely support more native animals, designs with non-natives will also enhance wildlife habitat. Gardens in similar settings harbor a variety of native animals including birds, insects, bats, lizards, salamanders, and small mammals. If the vertical walls along the Arroyo Seco were removed, western toads and Pacific chorus frogs may also visit the restored uplands.

Concerns for the success of upland restoration include potentially contaminated soils, physical barriers to recolonization, and space limitations. Plants may not be capable of surviving onsite if the soil is contaminated or nutrient-poor. Finally, the capacity of upland areas to support resident populations may be limited by the small area of habitat that will be available. Benefits to the public include enhanced recreation opportunities, plant and wildlife viewing opportunities, and reduced storm runoff from the site.

Enhancement of bat roosts - Bats are conspicuous inhabitants of many urbanized areas. Bats fall into two major groups: tree roosting species and crevice roosting species. These species are commonly found in many cities because high densities of large trees are routinely maintained as part of the urban landscape (Gehrt and Chelsvig, 2003, 2004). In southern California the red bat and the hoary bat are common tree-roosting species, and, because these animals do not roost communally, the addition of trees would benefit the population. In comparison, many crevice roosting species are communal roosters and have been observed to aggregate in large numbers beneath bridges and within other structures. Common crevice-roosting bats in the region include the big brown bat, the Yuma Myotis bat, and the Mexican free-tailed bat.

Recent studies have indicated that some bats are even more abundant in urban areas than neighboring agricultural landscapes, most likely because large urban trees and man-made structures provide essential roosts (Gehrt and Chelsvig, 2003, 2004). In Austin, Texas, between March and November an estimated 1.5 million Mexican free-tailed bats emerge nightly from their roosts beneath the Congress Avenue bridge; an estimated 100,000 people visit the site annually to witness this phenomenon. In addition to serving a general public interest in wildlife, a healthy bat population would help suppress pest insects, making the proposed park a more pleasant setting (Agosta, 2002). Planting native trees such as cottonwoods and sycamores in the confluence area would likely benefit species such as the red and hoary bats; the numerous bridges in the vicinity of the confluence likely support crevice nesting species, which would further benefit from the naturalization of the surrounding area.

\section{Potential tasks}

1. Initiate a biological inventory and monitoring program to document the current status of biota in the project area. If a goal is to remove part of the concrete lining, initial inventories should focus on the targeted area and also the currently unlined sections of the Los Angles
River upstream of the project area. The collection of baseline data and monitoring to document changes would help track progress towards project goals. Any monitoring work associated with this project should be coordinated with existing restoration studies upstream and in the headwater areas.

2. Evaluate feasibility and potential benefits of widening the river channels and creating sloping banks. Although replacing vertical concrete walls on both sides of the channel would best mimic natural conditions, replacing only the northern wall of the Arroyo Seco would achieve many of the same benefits.

3. Conduct post-development monitoring to evaluate project success in restoring habitat for riparian birds. The development of Confluence Park provides an opportunity to restore stream habitats for endangered and more common riparian birds. The design and construction of this restoration phase should be followed by data collection and monitoring to evaluate project success and to improve future restoration efforts.

4. Determine if bats are currently roosting under freeway and railroad bridges near the confluence area. If bats are present, this habitat value should be maintained or enhanced. Promote establishment of large native trees for the benefit of birds and bats.

\section{Summary and Discussion}

This report has identified a set of science issues that relate to the proposed development of a park at the confluence of the Los Angeles River and the Arroyo Seco, and has delineated a suite of potential work tasks to address these issues. The geological, hydrological, and biological issues are summarized below.

Geological issues of concern relate to surface faulting, earthquake ground motions, liquefaction, landsliding, and induced seismicity. The risk from potential surface faulting is considered to be low. There is a potential risk from earthquake ground motion because of the proximity of faults capable of producing large earthquakes and because of the amplification effect of the thin alluvium within the Glendale Narrows. The likely risks of liquefaction are uncertain at the Confluence Park site. Better determination of these risks would require more detailed assessment of ground-water levels and physical properties of the alluvial materials. Landslides are likely not a hazard for the confluence development, nor is induced seismicity.

Hydrological issues of concern relate to the hydraulics and water quality of both surface water and ground water. In general, the hydraulic effects related to the Confluence Park development are likely to be small given the relatively small 
volume of the proposed lake and the fact that no channellining removal is being considered for the Los Angeles River. Water-quality effects are more likely to pose concerns.

Flow in the Los Angeles River during non-storm periods has become increasingly dominated by discharge from waterreclamation facilities. This has hydraulic implications for the design and operation of a temporary lake. In addition, the dry-season flows in the river will deliver sediment that would accumulate within the lake. Discharge from reclamation facilities also affects the quality of water that would be impounded in the proposed lake. Creation of a lake allows for potential buildup of chemicals from the facilities and from other sources. In addition, the presence of a temporary lake increases the potential likelihood of human and animal exposure to chemical and microbial contaminants. Historical water-quality data for the Los Angeles River indicate periods with high dissolved oxygen concentrations during warm summer months. This may be indicative of algal blooms, which are of potential concern for a temporary lake.

Ground-water levels would likely be unaffected by a temporary lake in the lined portion of the Los Angeles River, but could be affected by channel-lining removal along the Arroyo Seco. Such lining removal also could affect groundwater quality. Ground-water quality could be affected if water from the lake were diverted to other locations for artificial ground-water recharge. Current ground-water contamination will have impacts on some proposed components of the Confluence Park.

Biological issues of concern include colonizationextinction dynamics, wildlife corridors, wildlife reintroduction, non-native species, ecotoxicology, and restoration of local habitat and ecology. For all of these issues, a key fact is that relatively modest enhancements in habitat values that result from the proposed Confluence Park would be a large improvement over current conditions. Colonization dynamics suggest that newly developed park/garden areas will eventually increase the species diversity. Given the small park area, however, only animals with small home ranges would be able to maintain self-sustaining populations. Many components of the proposed confluence area redevelopment would enhance the functioning of the Los Angeles River and the Arroyo Seco as wildlife corridors. Decisions on wildlife reintroduction in the confluence area will need to consider both the type and area of habitats required. Restoration of native species in the confluence area will be affected by the invasion of non-native plants and animals. The limited time period of operation of the proposed El Pueblo Lake probably would limit the likelihood of establishment of additional riparian and aquatic invasive species. Restoration of habitats in the confluence area also could be hindered by any chemical contamination that limits the group of species capable of surviving.

Individual design options for Confluence Park are considered in the context of their potential effect on restoration of local habitat and ecology. The temporary lake could attract insects and some amphibians that would use it as breeding habitat, although the lake would not be filled long enough to establish permanent populations of most aquatic species. The water quality in the lake could be detrimental to wildlife health. Channel-lining removal along the adjacent part of the Arroyo Seco could help restore riparian vegetation, which, in turn, could provide an effective habitat for a variety of native species, as well as invasive species such as giant reed Arundo donnax. Replacing any vertical channel walls along the Arroyo Seco with more mildly sloped banks would allow a greater diversity of species to move between the stream and upland habitats. Creating native plant gardens is included as part of the Confluence Park plans. Because the site currently supports sparse plant and animal life, any revegetation would be an improvement.

Table 3 summarizes a list of potential work tasks to address the geological, hydrological, and biological issues described above. Table 3 provides both a generalized list that could apply to a range of stream restoration projects and a site-specific list for the Confluence Park project. Note that while many of the proposed tasks involve data collection and analyses to be conducted prior to implementation of the Park, several of the hydrology tasks $(2,8,9,10)$ and most of the biology tasks $(1,3,4,6,8,10,13)$ involve ongoing monitoring during and after park development.

While this report has addressed scientific issues associated with a specific proposed project, table 3 illustrates how many of the specific tasks delineated for addressing science issues at Confluence Park can be generalized and considered for a range of restoration projects. In addition, the overall framework presented here for assessing the relevant geologic, hydrologic, and biologic issues associated with potential development of the Confluence Park could be applied to other stream restoration projects in different physiographic settings and at various scales. 
Table 3. Summary of potential general tasks for urban-stream restoration projects and specific tasks for the proposed development of Confluence Park.

\section{GEOLOGY}

\section{General tasks for urban stream restoration projects}

1A. Utilize seismic-geophysical methods to map relevant faults.

2A. Conduct trenching or borehole investigations to validate the seismic interpretations and to determine recency of fault activity and amount of fault movement.

3A. Incorporate fault information into design of project facilities.

4A. Derive probable earthquake ground motions using industry-standard techniques and incorporate into design standards for buildings and engineering works.

5A. Develop appropriate velocity profile(s) to evaluate near-surface shear-wave effects.

6A. Assess likelihood of seiche developing in any reservoir during an earthquake, and effect on temporary and permanent structures.

7A. Determine liquefaction susceptibility, utilizing cone penetrometer soundings, geotechnical boreholes, and installation of piezometers.

8A. Perform liquefaction-hazard analyses to assess the potential problem and as input in facilities design.

9A. Conduct slope stability analyses of proposed channellining removal.
Specific tasks for proposed development of Confluence Park

1B. Conduct a shallow, high-resolution seismic-reflection line to determine whether faults beneath the Confluence Park area in fact displace the Puente Formation and disrupt Quaternary strata.

2B. Same as general task $2 \mathrm{~A}$.

3B. Incorporate information on potential surface faulting into decisions on the placement of critical facilities in the Confluence Park area.

4B. Same as general task 4A.

5B. Determine a minimum 100-ft-deep shear-wave velocity profile for the Confluence Park area to better model near-surface site-amplification effects. Shear-wave measurements could be made in a borehole drilled for additional purposes.

6B. Model the proposed El Pueblo Lake to determine the likelihood of a seiche developing in this temporary lake during an earthquake. Evaluate the design of the clamps that anchor the portable dams in place to determine if they could withstand lateral loads imparted by the oscillations.

7B. Conduct a detailed subsurface investigation of the Confluence Park area to evaluate the liquefaction susceptibility of the underlying sediment. Such an investigation should involve the use of cone penetrometer soundings, several geotechnical boreholes, and installation of new piezometers.

8B. Perform liquefaction hazard analyses to assess the potential problem and as input in facilities design. Incorporate data from cone penetrometer soundings, geotechnical boreholes, and new piezometers.

9B. Conduct slope stability analyses along Arroyo Seco where channel-lining removal is proposed.

\section{HYDROLOGY}

General tasks for urban stream restoration projects

1A. Conduct an in-depth statistical analysis of relevant historical surface-water discharge data

2A. Evaluate existing surface-water monitoring network. Identify needs for additional gaging stations or more frequent data collection to adequately monitor stream restoration objectives.

3A. Conduct seepage runs to quantify changes in discharge resulting from any modification to the stream channel.

4A. Conduct a thorough statistical analysis of historical sediment data to quantify likely sedimentation effects of restoration activities.
Specific tasks for proposed development of Confluence Park

1B. Conduct an in-depth statistical analysis of historical surface-water discharge data for the Los Angeles River and the Arroyo Seco.

2B. Install or reactivate one or more gaging/sampling stations. One possible location would be on the Los Angeles River just downstream from the proposed lake. A second potential location would be at the lower end of the Arroyo Seco to monitor impacts of channel-lining removal.

3B. Conduct seepage runs along any newly unlined parts of the Arroyo Seco in order to quantify losses.

4B. Reevaluate historical sediment data for the months of interest (period of likely operation of El Pueblo Lake). 
Table 3. conintued

\section{HYDROLOGY}

\section{General tasks for urban stream restoration projects}

5A. If sediment impacts are considered likely, develop a sediment transport model that is based on, and calibrated to, recent sediment data collected at cross sections above, in, and below restoration area.

6A. Collect baseline surface-water quality data and assess suitability for proposed activities within the stream restoration area.

7A. Characterize the sources of surface-water flow, and assess the potential impact to the overall water-quality resulting from changes in the contribution of these sources, including recycled wastewater.

8A. Design and implement appropriate microbial monitoring plans to compliment the collection of chemical data (see Hydrology task 7A).

9A. Collect and compile water-level, water-quality, and temperature-log measurements in existing wells to establish baseline conditions in the stream restoration area.

10A. Establish sufficient ground-water monitoring/sampling stations to assess surface-water/ground-water conditions within the stream-restoration area, and with respect to the watershed.

11A. Assess the adequacy of the current geohydrologic characterization of the study area for evaluating ground-water/ surface-water conditions. Update as needed.

12A. Develop ground-water model(s) to assess hydraulic effects of different stream-restoration scenarios.

13A. Identify threats to water quality and assess the existing distribution of contaminants in ground water in, and adjacent to, the stream-restoration area.

14A. Assess the distribution of selected contaminants of concern in shallow sediment, and potential effect on stream water quality.

15A. Consider integration of specific restoration activities with regional water management activities.
Specific tasks for proposed development of Confluence Park

5B. Develop a sediment transport model that based on, and calibrated to, recent sediment data collected at cross sections above, in, and below the Confluence Park area. Evaluate likely possible sedimentation within the proposed El Pueblo Lake, and what happens to the sediment when the dam is deflated for winter flow each year.

6B. Collect additional surface-water-quality data to assess suitability for use in El Pueblo Lake during summer months, and for potential use as a source of ground-water recharge.

7B. Conduct a detailed assessment of effects of likely increase in discharge of recycled wastewater from the Donald C. Tillman, Burbank, and Los Angeles-Glendale water reclamation facilities (WRPs).

8B. Design and implement a microbial sampling/monitoring plan to characterize baseline conditions of effluent for the proposed El Pueblo Lake and to assess the suitability of this source for aquatic species (see Biology task 10B).

9B. In addition to general task 9A, design a network of groundwater sampling sites and collect new data to quantify potential changes associated with confluence development, such as channel-lining removal along the Arroyo Seco (see also general task 11A).

10B. Install new multiple-well monitoring well site(s) in the Glendale Narrows area to facilitate the collection of basic hydrologic, litho-stratigraphic, and water-quality data with good depth control.

11B. Develop a revised hydrostratigraphic framework for the Glendale Narrows area utilizing new and existing data.

12B. Develop a ground-water flow model to quantitatively assess the ground-water effects of alternative scenarios for lake design and channel-lining removal.

13B. Characterize the occurrence and transformation of selected ground-water contaminants of concern through compilation of existing data, and sampling of new and existing wells in the Glendale Narrows area.

14B. Conduct a one-time sampling of streambed sediment and selected aquatic-species tissue in the unlined portion of the Los Angeles River for constituents of concern (such as heavy metals, organochlorines, and semivolatile organic compounds.)

15B. Evaluate new locations for potential construction of new artificial recharge projects in adjacent areas to improve water quality and enhance ground-water recharge. 
Table 3. conintued

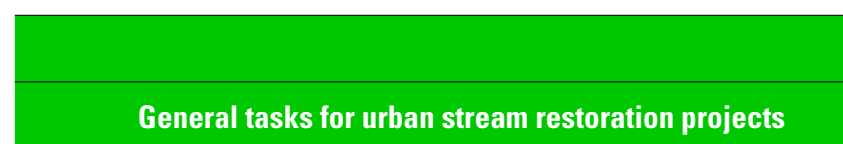

1A. Monitor species diversity within restoration area to assess impacts.

2A. Develop model of habitat and animal traffic for different restoration options

3A. Monitor wildlife traffic in and adjacent to restoration area.

4A. Inventory and monitor small flightless animals for 2 to 4 years after habitat restoration to determine what species rapidly colonize the site.

5A. Use wildlife-habitat relationship models to determine species that potentially could be supported in the study area.

6A. Conduct and monitor experimental wildlife introductions for selected species that have apparently failed to colonize on their own.

7A. Consider using topsoil relocation as a strategy for helping to establish a diverse community of native plants.

$8 \mathrm{~A}$. Inventory and monitor study area to determine the presence and population densities of invasive species of plants and animals. Evaluate programs for restricting population densities of these species.

9A. Create educational materials to inform visitors of local biological issues.

10A. Monitor contaminant concentrations in the water and the corresponding condition of aquatic animals in restored habitat area.

11A. Consider the inclusion off-channel pools that fill with rainwater as part of the habitat restoration.

12A. Assess biologic impacts of alternative designs for streamchannel geometry.

13A. Conduct pre- and post-development monitoring to evaluate impacts of project on specific species of concern.

\section{BIOLOGY}

\section{Specific tasks for proposed development of Confluence Park}

1B. Monitor the species diversity present in the area over time to assess impacts of any channel modification on the potential for immigration.

2B. Develop a model of the likely effects on habitat connectivity and animal traffic of a range of design options along the Los Angeles River corridor in the area of the Confluence Park.

3B. Monitor wildlife traffic along both the Los Angeles River and the Arroyo Seco.

4B. Same as general task 4A.

5B. Same as general task $5 \mathrm{~A}$.

6B. Same as general task $6 \mathrm{~A}$.

7B. Same as general task 7A.

8B Same as general task $8 \mathrm{~A}$.

9B. Same as general task 9A.

10B. Design and implement a plan-in conjunction with Hydrology tasks 6B, 8B, and 14B-for the collection of biological and microbial indicators to assess the overall health of the Confluence Park ecosystem.

11B. Same as general task $11 \mathrm{~A}$.

12B. Conduct evaluation to determine the benefits and feasibility of widening the channel bottom within the park.

13B. Conduct a post-development monitoring to evaluate project success in restoring habitat for endangered riparian birds. Determine if bats are currently roosting near the confluence area and develop a plan to maintain/enhance this habitat. 


\section{References Cited}

Agosta, S.J., 2002, Habitat use, diet and roost selection by the Big Brown Bat (Eptesicus fuscus) in North America: a case for conserving an abundant species: Mammal Review, v. 32, p. $179-198$.

Anders, Robert, Yanko, W.A., Schroeder, R.A., and Jackson, J.L., 2004, Virus fate and transport during recharge using recycled water at a research field site in the Montebello Forebay, Los Angeles County, California, 1997-2000: U.S. Geological Survey Scientific Investigations Report 20045161.

Anders, R., Schroeder, R.A., 2003, Use of water-quality indicators and environmental tracers to determine the fate and transport of recycled water in Los Angeles County, California: U.S. Geological Survey Water-Resources Investigations Report 03-4279, 104 p.

Atwater, T.A., 1970, Implications of plate tectonics for the Cenozoic tectonic evolution of western North America: Geological Society of America Bulletin, v. 81, p. 35133536.

Bates, R.L., and Jackson, J.A., eds., 1980, Glossary of Geology, 2nd ed.: American Geological Institute, 749 p.

Bay, S.M., Jones, B.H., and Schiff, K.C., 1999, Study of the impact of stormwater discharge on Santa Monica Bay: Southern California coastal water research project: Westminster, Calif., 16p.

Belitz, K., Hamlin, S.N., Burton, C.A., Kent, R.H., Fay, R.G., Johnson, T., 2004, Water-quality in the Santa Ana basin, California, 1999-2001: U.S. Geological Survey Circular 1238, 37 p.

Bennett, J.P., 2001, User's guide for mixed-size sediment transport model for networks of one-dimensional open channels: U.S. Geological Survey Water-Resources Investigations Report 01-4054, 39 p.

Block W.A., Franklin, A.B., Ward, J.P., and others, 2001, Design and implementation of monitoring studies to evaluate the success of ecological restoration on wildlife: Restoration Ecology, v. 9, no. 3, p. 293-303.

Bolger, D.T., Scott, T.A., and Rotenberry, J.T., 2001, Use of corridor-like landscape structures by bird and small mammal species: Biological Conservation, v. 102, no. 2, p. 213-224.
Brownlie, W.R., Taylor, B.D., 1981, Sediment Management for Southern California Mountains, Coastal Plains and Shoreline; Part C, Coastal Sediment Delivery by Major Rivers in Southern California: Environmental Quality Laboratory Report No. 17-C. California Institute of Technology, Pasadena.

Burton, C.A., 2002, Effects of urbanization and long-term rainfall on the occurrence of organic compounds and trace elements in reservoir sediment cores, streambed sediment, and fish tissue from the Santa Ana river basin, California, 1998: U.S. Geological Survey Water-Resources Investigations Report 02-4175, 73 p.

California Department of Water Resources, 1961, Planned utilization of the ground water basins of the coastal plain of Los Angeles County, Appendix A, Ground Water Geology: California Department of Water Resources Bulletin 104, $191 \mathrm{p}$.

California Geological Survey, 1998, Seismic hazard evaluation of the Los Angeles 7.5-minute quadrangle, Los Angeles County, California: California Division of Mines and Geology Open-File Report 98-20, 35 p.

California Geological Survey, 2002, The revised 2002 California probabilistic seismic hazard maps, June 2003 revision of Petersen, M.D., Bryant, W.A., Cramer, C.H., Cao, Tianqing, Reichle, M. S., Frankel., A.D., Lienkaemper, J.J., McCrory, P.A., and Schwartz, D.P., 1996, Probabilistic seismic hazard assessment for the state of California: California Department of Conservation, Division of Mines and Geology Open-File Report 96-08, 9 p. plus appendixes.

California Resources Agency, 2001, Common ground from the water to the sea: Watershed and open space plan - San Gabriel and Los Angeles Rivers, October 2001.

Christensen, J., 2003, Auditing conservation in an age of accountability: Conservation In Practice, v. 4, no. 3., <http:// www.conbio.org/inpractice/article43AUD.cfm>.

Christensen, J., 2004, Is conservation ready for the light of day: Conservation In Practice, v. 5, no. 1., <http://www. conbio.org/inpractice/Uneasychair51.cfm $>$.

City of Los Angeles, 2004, El Pueblo Lake Initial Concept Study: Draft prepared by Bureau of Engineering, April 2004, p. 17.

Constantz, James, and Essaid, H.J., 2003, The influence of ground water on stream restoration following dam removal: EOS, Transactions American Geophysical Union Fall Meeting Supplemental, Abstract H21D-0870, v. 84, no. 46, p. F626 
Davis, T.L., Namson, J., and Yerkes, R.F., 1989, A cross section of the Los Angeles area: Seismically active fold and thrust belt, the 1987 Whittier Narrows earthquake, and earthquake hazard: Journal of Geophysical Research, v. 94, no. 7 , p. 9644-9664.

Environmental Resources Management, 2000, Phase 4: Soil and groundwater data gaps investigation, Taylor Yard, Los Angeles, California: Irvine, Calif., 39 p.

Fumal, T.E., and Tinsley, J.C., 1985, Mapping shear-wave velocities of near-surface geologic materials in Ziony, J.I., ed., Evaluating earthquake hazards in the Los Angeles region - an earth-science perspective: U.S. Geological Survey Professional Paper 1360, p. 127-150.

Garrett, K.L. (ed.), 1993, The biota of the Los Angeles river: Natural History Museum of Los Angeles County Foundation, $80 \mathrm{p}$.

Gath, E.M., Gonzalez, T., and Rockwell, T.K., 1992, Slip rate of the Whittier fault based on 3-D trenching at Brea, southern California: Geological Society of America Cordilleran Section Meeting, May 11-13, 1992, v. 24, p. 26.

Gehrt, S.D., and Chelsvig J.E., 2003, Bat activity in an urban landscape: Patterns at the landscape and microhabitat scale: Ecological Applications, v. 13, p. 939-950.

Gehrt, S.D., and Chelsvig J.E., 2004, Species-specific patterns of bat activity in an urban landscape: Ecological Applications, v. 14, p. 625-635.

Grant, S.B., and others, 2001, Generation of enterococci bacteria in a coastal salt water marsh and its impact on surf zone water quality: Environmental Science and Technology, v. 35 , no. 12 , p. $2407-2415$.

Gumprecht, Blake, 2001, The Los Angeles River, Its life, death, and possible rebirth: The Johns Hopkins University, Baltimore, $369 \mathrm{p}$.

Harbaugh, A.W., Banta, E.R., Hill, M.C., and Mc Donald, M.G., 2000, Modflow-2000, The U.S. Geological Survey modular ground-water model-User guide to modularization concepts and the ground-water flow process: U.S. Geological Survey Open-File-Report 00-92, 121 p.

Hillhouse, J.W., Reichard, E.G., Ponti, D.J., 2002, Probing the Los Angeles Basin; insights into ground-water resources and earthquake hazards: U.S. Geological Survey Fact Sheet 086-02, 2 p.

Hunter, R.D., Fisher, R.N., and Crooks, K.R., 2003, Landscape-level connectivity in coastal southern California, USA, as assessed through carnivore habitat suitability: Natural Areas Journal, v. 23, p. 302-314.
Inman, D.L., and Jenkins, S.A., 1999, Climate change and the episodicity of sediment flux of small California rivers: Journal of Geology, v. 107, p.251-270.

Izbicki, J.A., Mendez, G.O., and Burton, C.A., 2000, Stormflow chemistry in the Santa Ana River below Prado Dam and at the diverson downstream from Imperial Highway, Southern California, 1995-98: U.S. Geological Survey Water-Resources Investigations Report 00-4127, 92 p.

Keefer, D.K., 1984, Landslides caused by earthquakes: Geological Society of America Bulletin, v. 95, no. 4, p. 406421.

Keitt, B.S., Wilcox, C., Tershy, B.R., and others, 2002, The effect of feral cats on the population viability of blackvented shearwaters (Puffinus opisthomelas) on Natividad Island, Mexico: Animal Conservation, v. 5, p. 217-223.

Kent, R.H., and Belitz, K., 2004, Concentrations of dissolved solids and nutrients in water sources and selected streams of the Santa Ana Basin, California, October 1998-September 2001: U.S. Geological Survey Water-Resources Investigations Report 03-4326, 61 p.

Kundert, J.C., 1955, Geologic map of California, Los Angeles sheet: California Division of Mines.

Lamar, D.L., 1970, Geology of the Elysian Park - Repetto Hills area, Los Angeles County, California: Calif. Div. of Mines and Geology Special Report 101, 45 p.

Land, Michael, Everett, R.R., and Crawford, S.M., 2002, Geologic, hydrologic, and water-quality data from multiple-well monitoring sites in the Central and West Coast Basins, Los Angeles, County, California, 1995-2000: U.S. Geological Survey Open-File Report 01-277, 178 p.

Longcore T., 2003, Terrestrial arthropods as indicators of ecological restoration success in coastal sage scrub (California, USA): Restoration Ecology, v. 11, no. 4, p. 397-409.

Los Angeles County Department of Public Works, 1996, Los Angeles River master plan, variously paged.

Los Angeles County Department of Public Works, 2003, Los Angeles River master plan implementation, 46 p.

Madden-Smith, M.C., Atkinson, A.J., Fisher, R.N., Danskin, W.R., Mendez, G.O., 2004, Assessing the risk of Loveland Dam operations to the Arroyo Toad (Bufo californicus) in the Sweetwater River channel, San Diego County, California, 58 p., <http://www.werc.usgs.gov/sandiego/pdfs/Sweetwater_Risk_Assessment_Final_020304.pdf>.

McFadden, L.D., 1982, The impacts of temporal and spatial climatic changes on alluvial soils genesis in southern California: University of Arizona Unpublished Ph. D. Dissertation, $430 \mathrm{p}$. 
Merritt, M.L., and Konikow, L.F., 2000, Documentation of a computer program to simulate lake-aquifer interaction using the MODFLOW ground-water flow model and the MOC3D solute-transport model: U.S. Geological Survey WaterResources Investigation Report 00-4167, 146 p.

Miller Brooks Environmental and California State University, 2002, Taylor Yard and Los Angeles River-Preliminary groundwater and surface water study, groundwater model of Taylor Yard and vicinity, Los Angeles, California: A report to the California Coastal Conservancy and the Los Angeles and San Gabriel Rivers Watershed Council, 53 p.

Nelson, J.W., Zinn, C.J., Strahorn, A.T., Watson, E.B., and Dunn, J.E., 1919, Soil survey of the Los Angeles area, California: Field Operations of the Bureau of Soils, 1916, 80 p., plate.

NorthEast Trees and Arroyo Seco Foundation, 2002, Arroyo Seco watershed restoration feasibility study: Volume I (Project report); Volume II (Technical appendices), prepared for California Coastal Conservancy, Oakland, Calif., May 31, 2002, $291 \mathrm{p}$.

OpenSHA Model, accessed November 28, 2003 at $<$ http:// www.opensha.org >.

Oskin, M., Sieh, K., Rockwell, T., Miller, G., Guptill, P., Curtis, M., McArdle, S., and Elliot, P., 2000, Active parasitic folds on the Elysian Park anticline: Implications for seismic hazard in central Los Angeles, California: Geological Society of America Bulletin, v. 112, p. 693-707.

Price J., 2003, Case Study: Confluence Park, Los Angeles: Los Angeles Forum for Architecture and Urban Design, Issue 5, June 2003, <http://www.laforum.org/issues/issue5. php>.

Prudic, D.E., Konikow, L.F., and Banta, E.R., 2004, A streamflow routing package (SFR1) to simulate stream-aquifer interaction with MODFLOW-2000 ground-water flow model: U.S. Geological Survey Open-File Report 2004$1042,95 \mathrm{p}$.

Reichard, E.G., Land, Michael, Crawford, S.M., Johnson, Tyler, Everett, R.R., Kulshan, T.V., Ponti, D.J., Johnson, T.A., Paybins, K.S., and Nishikawa, Tracy, 2003, Geohydrology, geochemistry, and ground-water simulationoptimization of the Central and West Coast Basins, Los Angeles, County, California: U.S. Geological Survey WaterResources Investigations Report 03-4065, 184 p.

Rockwell, T.K., Klinger, R., and Goodmacher, J., 1990, Determination of slip rates and dating of earthquakes for the San Jacinto and Elsinore fault zones, in Kooser, M.A., and Reynolds, R.E., eds., Geology around the Margins of the eastern San Bernardino Mountains, Volume 1: Inland Geological Society, Redlands, p. 51-56.
Santa Monica Mountains Conservancy, 2003, Conservancy announces acquisition of phase one of $\$ 7$ million for park project near downtown Los Angeles: News Release, March 14, 2003 (Contact: Dash Stolarz).

Southern California Coastal Water Research Project, 2004, <http://www.sccwrp.org/about/rspln2003-2004.html>.

Schroeder, R.A. (editor), 2003, Water-quality changes and organic-carbon characterization during recharge with recycled water at a Research Basin in Montebello Forebay, Los Angeles County, California, 1991-1996: U.S. Geological Survey Water-Resources Investigations Report 03-4146, $260 \mathrm{p}$.

Schwartz, D.P., Joyner, W.B., Stein, R.S., Brown, R.D., McGarr, A.F., Hickman S.H., and Bakun, W.H., 1996, Review of seismic-hazard issues associated with the Auburn Dam project, Sierra Nevada foothills, California: U.S. Geological Survey Open-File Report 96-0011.

Semlitsch, R.D, 2002, Critical elements for biologically based recovery plans of aquatic-breeding amphibians: Conservation Biology, v. 16, p. 619-629.

Shaw, J.H., Plesch, A., Fiore, P., Dolan, J., Christofferson, S., Pratt, T.L., Williams, R., and Odum, J., 2000, Structural geometry, segmentation, and slip on the Puente Hills blindthrust system: Implications for earthquake hazards in metropolitan Los Angeles: EOS, Transactions of the American Geophysical Union, Annual Fall Meeting, p. F850.

Shaw, J.H., and Shearer, P.M., 1999, An elusive blind-thrust fault beneath metropolitan Los Angeles: Science, v. 283, p. 1516-1518.

Shaw, J.H., and Suppe, J., 1996, Earthquake hazards of active blind-thrust faults under the central Los Angeles basin, California: Journal of Geophysical Research, v. 101, p. 8623-8642.

Simpson, D. W., 1976, Seismicity changes associated with reservoir impounding: Engineering Geology, v. 10, p, 371-385.

Spinks, P.Q., Pauly, G.B., Crayon, J.J., and others, 2003, Survival of the western pond turtle (Emys marmorata) in an urban California environment: Biological Conservation, v. 113 , no. 2 , p. 257-267.

State of California, accessed January 3, 2005 at $<$ http://www. westnile.ca.gov/>.

Trenham, P.C., and Marsh, D.M., 2002, Amphibian translocation programs: response to Seigle and Dodd: Conservation Biology, v. 16, p. 555-556.

Wallace, G.D., 1993, Report on the vascular plants of the Los Angeles River, in Garrett, K.L., ed., The biota of the Los Angeles river: p. B1-B16. 
Water Replenishment District of Southern California, 2004a, Engineering survey and report 2004: Cerritos, Calif.

Water Replenishment District of Southern California, 2004b, Regional groundwater monitoring report, water year 20022003: Cerritos, Calif.

Weiss, S.B., 1999, Cars, cows, and checkerspot butterflies: nitrogen deposition and management of nutrient-poor grasslands for a threatened species: Conservation Biology, v. 13, no. 6, p. 1476-1486.

Woodford, A.O., Schoellhamer, J.E., Vedder, J.G., and Yerkes, R.F., 1954, Geology of the Los Angeles basin: California Division of Mines and Geology Bulletin 170, chap. II, p. 65-81.

Yerkes, R.F., McCulloh, T.H., Schoellhamer, J.E., and Vedder, J.G., 1965, Geology of the Los Angeles basin, California - An introduction: U.S. Geological Survey Professional Paper 420-A, 57 p.

Yerkes, R.F., Tinsley J.C., and Williams, K.M., 1977, Geologic aspects of tunneling in the Los Angeles Area: U.S. Geological Survey Miscellaneous Field Study 77-680,

67 p., 5 plates.

Youd, T.L., 1973, Liquefaction, flow and associated ground failure: U.S. Geological Survey Circular 688, 12 p.

Youd, T.L., 1978a, Major cause of earthquake damage is ground failure: Civil Engineering, v. 48, no. 4, p. 47-51.

Youd, T.L., 1978b, Mapping liquefaction-induced ground failure potential: Proceedings of the American Society of Civil Engineers: Journal of the Geotechnical Engineering Division, v. 104, no. GT4, p. 433-446. 


\title{
Acknowledgements
}

\section{Technical Support}

\author{
Chuck Arnold (MRCA) \\ James Bennett (USGS) \\ Kathleen Bullard (MRCA) \\ Dale Cox (USGS) \\ Sean Devlin (USGS) \\ Robert Fisher (USGS) \\ Gary Fuis (USGS) \\ Lucy Jones (USGS) \\ Cara McClane (MRCA) \\ Michael Nolan (USGS) \\ Michael Shulters (USGS) \\ Lisa Soghor (MRCA) \\ Walter Swain (USGS) \\ T'Shaka Toure (USGS)
}

\section{Editorial, Graphics and Layout}

Myrna DeBortoli (USGS)

Tyler Johnson (USGS)

Alice McCracken (USGS)

Laurel Rogers (USGS)

Jerry Woodcox (USGS)

\section{Report Review and Approval}

Kenneth Belitz (USGS)

Gary Busteed (NPS-National Park Service)

Thomas Fumal (USGS)

Rick Iwatsubo (USGS)

Charles Kaehler (USGS)

Keith Kirk (USGS)

Gregory Lines (USGS) 